\title{
Global science. Development and novelty
}

\author{
Collection of scientific papers \\ on materials \\ X International Scientific Conference
}

25.12.2019 г.

Part 1

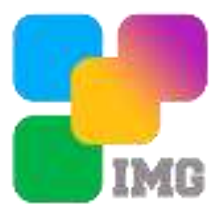

Munich 2019 
Global science. Development and novelty. Collection of scientific papers, on materials of the $\mathrm{X}$ International scientific-practical conference 25.12.2019 Ed. SPC "LJournal", 2019. - 88 p.

Global science. Development and novelty. Сборник научных трудов по материалам $\mathrm{X}$ международной научно-практической конференции. 25.12.2019 Изд.. НИЦ "Л-Журнал", 2019. - 88 с.

\section{SPLN 001-000001-0562-GS \\ DOI 10.18411/gdsn-25-12-2019-p1 \\ IDSP scienceconf-gdsn-25-12-2019-p1}

The collection of scientific papers of the materials collected from different areas of scientific knowledge. This publication contains all the materials that were sent to the X International scientific conference "Global science. Development and novelty"

The collection is intended for researchers, teachers and students

All materials contained in the book, published in the author's version. The editors do not make adjustments in scientific articles. Responsibility for the information published in the materials on display, are the authors.

Information about the published articles will be transferred in the Russian Science Citation Index (RISC)

The electronic version of the collection is available online scientific publishing center «L-Journal." Site center: science-conf.com

UDC 001.1

LBC 60 


\section{Соgержанше}

РАЗДЕЛ І. МАТЕМАТИКА

Рузманов Ф.И., Ашуров Б.Н., Комилов Т.О., Умедов Ш.Х. Результаты спектрального анализа эффективной промывочной жидкости с применением ОПР .......5

РАЗДЕЛ II. ТЕХНИЧЕСКИЕ НАУКИ 8

Аксяитов М.Х., Егорова Е.В., Рыбаков А.Н. Цифровой ускоритель системы

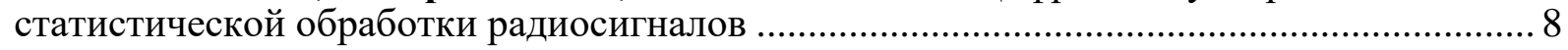

Вульфсон И.И. Применение псевдорезонансов в машинах с реономными связями .... 12

Петров А.Л., Баева Л.С., Петрова Н.Е., Кумова Ж.В. Анализ композиционных материалов как элемента металлозамещения.

Boyarineva I.V., Khamagaeva I.S. Development of technology for a new bacterial concentrate .

Tsarev T.A. Practical use of opportunities of the center of youth innovative creativity in Karelia 28

РАЗДЕЛ III. МЕДИЦИНА

Ахундова А.А. Функциональное состояние почек у новорожденных с задержкой внутриутробного развития .... 31

Ахундова Н.Э. Особенности гормональных изменений у женщин с гипертиреозом и с синдромом гиперандрогении репродуктивного возраста

Алиева С.C. Соответствие критериям USPHS двухслойных и монолитных циркониевых реставраций: результаты исследования в течение 3 -х лет ......................... 39

Закизаде А. Э., Гурбаналиева Г.И. Клинические и лечебные аспекты при воспалительных заболеваниях пародонта

Ибрагимов Ф.И. Актуальные аспекты стратегии и тактики хирургического лечения тяжелых сочетанных травм 44

Касимова С.О. Изучение привязанности в контексте интерперсональной психотерапии депрессии

Мамедова С.Н. Характеристика степени обсемененности околоплодных вод при преждевременном разрыве околоплодных оболочек, a также слизи верхних дыхательных путей у новорожденных с РДС, родившихся от матерей с преждевременным разрывом плодных оболочек в условиях РПЦ города Баку............... 50

Мамедова В.Г. Влияние подключения аторвастатина к базисной терапии больных ишемической болезнью сердца и артериальной гипертензией, сочетанных с дислипидемией

Талыблы А.А. Влияние синдрома гиперандрогении на особенности физического развития девочек в периоде полового созревания ..... .58

Garashova M.A. Incidence of tumors of the reproductive system in the postmenopausal period in the republic of Azerbaijan.

Gasimzade G.Sh. Early diagnosis of traumatic brain injury

Kazımzade J.R. Experience of using minimally invasive interventions in infected pancreonecrosis

Mehdiyeva L.A. On the issue of polycystic ovary syndrome in patients in the region of chronic iodine deficiency 
Moskalets O.V. The value of some laboratory taests as predictors of outcomes of postoperative outcomes inflammatory reactions after cataract surgery ................................. 70

Petrov A.A., Sobennikova V.V. Clinical dynamics of the problematic use of the Internet in patients with personality disorders according to a 2 -year catamnestic monitoring 71

РАЗДЕЛ IV. БИОЛОГИЯ .78

Шишелова А.Ю., Смирнов К.С. Влияние ранней социальной изоляции на поведение во взрослом возрасте зависит от критического периода постнатального онтогенеза..... 78

Шишелова А.Ю., Алексанян О.В. Формирование поведения крыс линии WAG/Rij зависит от материнской заботы в раннем постнатальном онтогенезе 


\section{РАЗДЕЛ І. МАТЕМАТИКА}

\section{Рузманов Ф.И., Ашуров Б.Н., Комилов Т.О., Умедов Ш.Х. Результаты спектрального анализа эффективной промывочной жидкости с применением ОПР}

(Узбекистан, Ташкент)

doi: $10.18411 / g d s n-25-12-2019-01$

idsp: scienceconf-25-12-2019-01

\section{Аннотация}

В статье рассматривается результаты спектрального анализа эффективной промывочной жидкости с применением ОПР. На основе спектрального исследования показано, что механизм ионного обмена частиц промывочной жидкости (реакция замещения) при замене в кристаллической решетке минерала катионами дисперсной среды представляет собой необменное замещение органических и неорганических катионов промывочной жидкости с частицами породы и целыми группами дисперсионной среды. Получены результаты процессов присоединения к частицам промывочной жидкости элементов флюидов и породы, а также одновременно происходящие ионообменные и необменные процессы, определяющие механизмы ингибирования (снижения гидрофильности), стабилизации и коллоидной защиты в промывочных жидкостях - дисперсных системах.

Ключевые слова: ИК-спектрометра, полимер, флюид, гидрофильности, дисперсная система, коагуляция, твердой фазы, гидратных пленок, окристаллизованность.

Спектральный анализ эффективной промывочной жидкости с применением ОПР в сравнении с базой данных ИК-спектрометра показывает наибольшие совпадения со спектрами молекул известных полимеров (рис.1-2).

Поскольку, представленная промывочная жидкость многокомпонентная, состоящая из органических, неорганических и полимерных соединений, формы порошка или волокна, то выбрана была универсальная для всех методика ATR (ослабленное полное отражение) в спектральном интервале 4000-400 см-1.

На основе спектрального анализа следует, что механизм ионного обмена частиц промывочной жидкости (реакция замещения) при замене в кристаллической решетке минерала катионами дисперсной среды представляет собой необменное замещение органических и неорганических катионов промывочной жидкости с частицами породы и целыми группами дисперсионной среды $[1,2,3]$.

Получены результаты процессов присоединения к частицам промывочной жидкости элементов флюидов и породы, а также одновременно происходящие ионообменные и необменные процессы, определяющие механизмы ингибирования (снижения гидрофильности), стабилизации и коллоидной защиты в промывочных жидкостях - дисперсных системах.

Определены режимы коагуляции дисперсных систем взаимодействия промывочной жидкости с элементами флюидов. Изучена коагуляция дисперсных систем взаимодействия промывочной жидкости с частицами породы. Получены результаты анализа коагуляции дисперсных систем взаимодействия промывочной жидкости, с элементами флюидов и частицами породы. Обобщены процессы коагуляции дисперсных систем в результате взаимодействия промывочной жидкости с элементами флюидов и частицами породы на молекулярном уровне.

В настоящее время большое внимание уделяется проблеме управления процессами структурообразования в минерализованных полидисперсных суспензиях [4,5]. Структура дисперсной системы возникает в результате взаимодействия частиц ее твердой фазы, на 
углах и ребрах утонченных гидратных пленок, легко взаимодействующих с молекулярными силами и образующих сетчатую структуру.

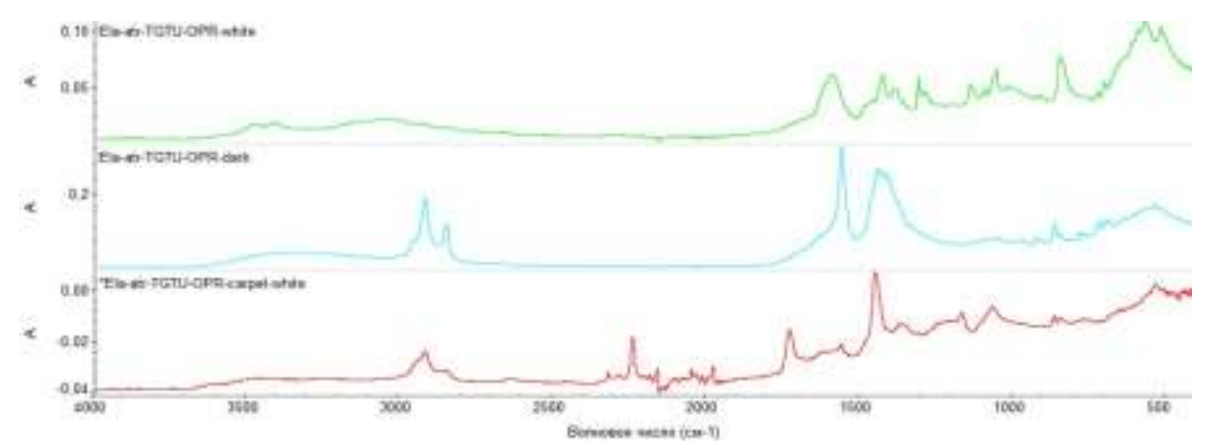

Рис. 1. ИК-спектры компонент ОПР: 1 - ОПР (белая фракичя); 2 - ОПР (темная фракция); 3 - Белые волокна (отходыл ковров).

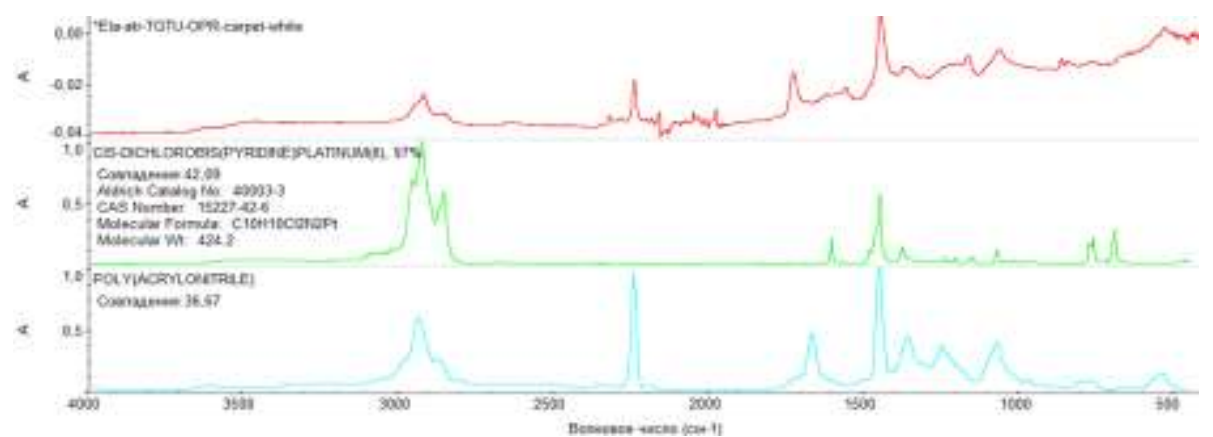

Рис. 2. ИК - спектры компоненты ОПР из отходов ковров в сравнении с базой данных ИК-спектрометі небольшому совпадению со спектрами молекуль известных полимеров: 1 - ИК-спектр компонентов ОІІР из отходов ковров; 2 - ИК-спектр ЦИС-дихлоробис (пиридин) платинум (II), совпадение - 42\%; 3 - ИК-спектр поли(акрилонитрил), совпадение $\sim 36,6 \%$.

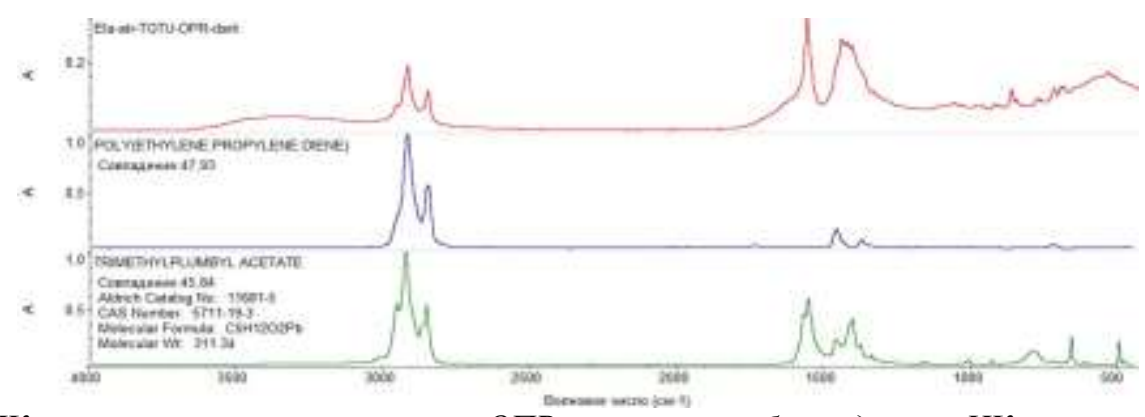

Рис. 3. ИК-спектры темной компоненты ОПР в сравнении с базой данных ИК-спектрометра пс наибольшему совпадению со спектрами молекул известных полимеров: 1 - спектр темной компоненть ОПР; 2 - спектр поли(этилен-пропилен-диен), степень совпадения - 48\%; 3 - спектр триметилплюмбил ацетана, совпадение 46 .

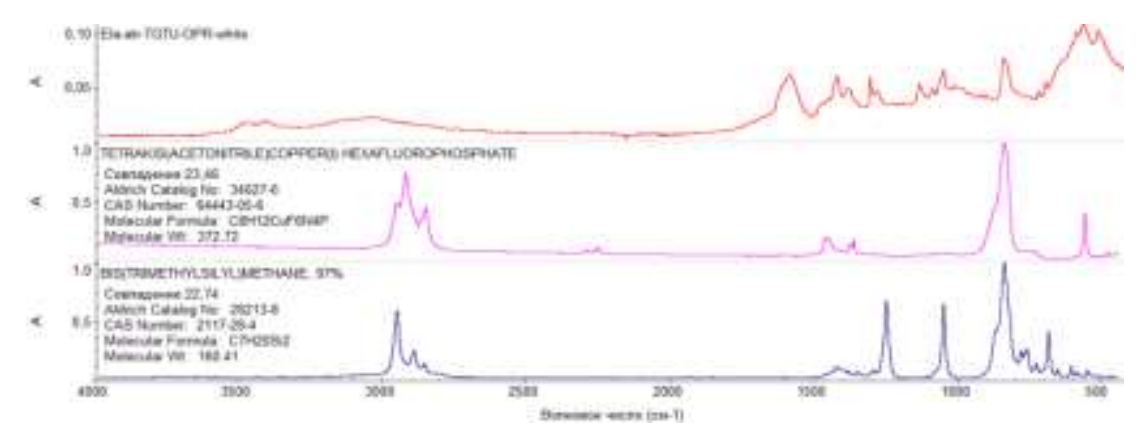

Рис. 4. ИК - спектры компоненты белой ОПР в сравнении данных ИК-спектрометра по наибольши совпадению со спектрами молекул и известных полимеров: 1 - ИК-спектр белой компоненты ОПР ; -

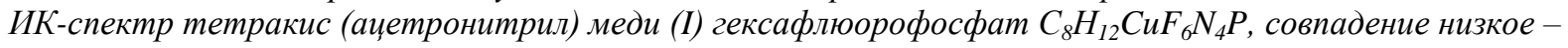
$23 \%$, наверное это неорганическое соединение, его нет в базе ИК-спектров молекулярных органических соединений; 3 - ИК-спектр БИС (триметилсилил) метан $\left(\mathrm{C}_{7} \mathrm{H}_{20} \mathrm{Si}_{2}\right)$. 
Обобщение результатов схемы действия молекулярных сил при взаимодействии промывочной жидкости с флюидами и породой на молекулярном уровне:

1. Приведённые результаты ИК-спектроскопических исследований растворимых фракций показывают, что полосы поглощения, характерные для гидролизованных полиакрилонитрила, а спектры нерастворимых фракций дают полосы поглощения, присущие волокнам целлюлозы и шерсти, так, например, наблюдаются валентные колебания при $3440 \mathrm{~cm}^{-1}$, характерные для ОН- групп, а также полосы при $3100 \mathrm{~cm}^{-1}, 1410 \mathrm{~cm}^{-1}, 1100 \mathrm{~cm}^{-1}, 980 \mathrm{~cm}^{-1}$ (рис.2).

2. Представлено электронное изображение структуры реагента ОПР, влияющее на концентрацию и состав твердой фазы, тип кристаллической решетки структурообразующих единиц, конфигурацию частиц, их окристаллизованность, способность к изоморфному замещению, число активных центров, количество связанной воды и т.д., а также влияющего на процессы структурообразования промывочной жидкости.

3. Сравнительный спектральный анализ эффективной промывочной жидкости с применением ОПР с базой данных ИК-спектрометра показывает наибольшее совпадение со спектрами молекул известных полимеров, который выявил, что механизм ионного обмена частиц промывочной жидкости (реакции замещения) при замене в кристаллической решетке минерала катионами дисперсной среды представляет собой необменное замещение органических и неорганических катионов промывочной жидкости с частицами породы и целыми группами дисперсионной среды.

1. Махаматхожаев Д.Р., Комилов Т.О., Рахматов Ш.Д., Санетуллаев Е.Е. Разработка состава бурового раствора для вскрытия продуктивных горизонтов на месторождениях Ферганской нефтегазоносной области // Научно-технический журнал «Технологии нефти и газа» Москва, 2018. - №6.-С. 36-41.

2. Акрамов Б.Ш., Умедов Ш.Х., Мирсаатова Ш.Х., Нуритдинов Ж.Ф., Комилов Т.О., Вскрытие продуктивного пласта с применением пен // Научно-технический журнал «Технологии нефти и газа» Москва 2017 - №4. С. 35-39.

3. Akramov B.Sh, Umedov Sh.Kh. Oil-and-gas production handbook. Tashkent- "Fan va tekhnologiya", 2010.

4. Umedov Sherali Xalloqovich. Effective composition of washing fluid on base the waste products when opening the productive horizon //European Applied Sciences. - Germany, 2015. - \#12. - C. 52-53.

5. Рахимов К.А., Комилов Т.О., Рахимов А.А., Рахимов А.К. Использование промывочных жидкостей на основе смазочных веществ для предотвращения прихвата. Технологии нефти и газа Научнотехнический журнал - Москва, 2019.- №2. - С. 42-45. 


\section{РАЗДЕЛ ІІ. ТЕХНИЧЕСКИЕ НАУКИ}

\section{Аксяитов М.Х. ${ }^{1}$, Егорова Е.В. ${ }^{2}$, Рыбаков А.Н. ${ }^{2}$ Цифровой ускоритель системы статистической обработки радиосигналов}

${ }^{1}$ АО Кониерн «Гранит-Электрон»

${ }^{2}$ ФГУП ВНИИА им. Н.Л. Духова

${ }^{1}$ (Россия, Санкт-Петербург)

${ }^{2}$ (Россия, Москва)

doi: 10.18411/gdsn-25-12-2019-02

idsp: scienceconf-25-12-2019-02

\section{Аннотация}

Представлена блок-схема устройства для вычисления апостериорной вероятности, представляющего собой аппаратный ускоритель операций статистической обработки данных. Рассмотрена структурная схема системы цифровой обработки радиосигналов, использующей аппаратное ускорение статистических операций и определен поход для обработки сигналов эталонных стандартов частоты времени. Предложен метод статистической обработки позволяет повысить помехоустойчивость системы обработки радиосигнала, и при этом использует компоненты и методы проектирования современной микроэлектронной промышленности.

Ключевые слова: радиолокационное распознавание, программируемые логические интегральные схемы, масштаб распределения плотности вероятности ошибки, апостериорная вероятность, эталонные стандарты частоты времени.

\section{Abstract}

A block diagram of a device for calculating a posteriori probability, which is a hardware accelerator of statistical data processing operations, is presented. A structural diagram of a digital radio signal processing system using hardware acceleration of statistical operations is considered, and a path for processing signals of reference time frequency standards is determined. A statistical processing method is proposed that improves the noise immunity of the radio signal processing system, and at the same time uses components and design methods supported by the modern microelectronic industry.

Key words: radar recognition, programmable logic integrated circuits, the scale of the distribution of the probability density of error, posterior probability, reference standards for the frequency of time.

Важным направлением развития современной радиолокации является - создание методов получения наиболее полной информации, содержащейся в радиолокационных сигналах и помехах. Радиолокационное распознавание является частью данного направления. В качестве дополнительной информации о распознаваемых объектах в активной радиолокации используются характеристики создаваемого целями поля вторичного излучения в дальней зоне радиолокаторов радиолокационных станций (РЛС). Радиолокационными характеристиками объектов при активной радиолокации являются: эффективная площадь рассеяния, спектральные и временные характеристики отраженных от цели сигналов, содержащие информацию о параметрах движения цели, ее форме, размерах, модуляции, вызванной вращением турбин, винтов, а также колебаниями различных частей объектов военного назначения, поляризационные характеристики сигналов, отраженных от целей. Данные характеристики, как правило, зависят от ориентации цели, параметров ее движения, размеров, типов, установленных на ней двигателей и режимов их работы, параметров вибраций корпуса, а также от характеристик зондирующих сигналов, способа обработки принимаемых сигналов и т.д. 
В процессе получения радиолокационной информации решаются следующие основные задачи: обнаружение целей, измерение параметров их движения, разрешение целей и распознавание целей. Возможно несколько подходов к классификации методов распознавания. Наиболее широко используется классификация методов распознавания в зависимости от типа зондирующего сигнала, используемого в РЛС.

Радиолокационное распознавание - это получение радиолокационных характеристик различных объектов, выбор информативных и устойчивых признаков и принятие решения о принадлежности этих объектов к тому или иному классу (типу). Информация о радиолокационных характеристиках объектов может быть получена методами как активной, так и пассивной радиолокации. При активной радиолокации определение радиолокационных характеристик объектов основано на отражении радиоволн от объектов, или на вторичном излучении объектов. При пассивной радиолокации может использоваться естественное радиоизлучение целей (радиотеплолокация) либо радиоизлучение бортовых источников радиосигналов и помех (преднамеренных и непреднамеренных).

Развитие оптимальных методов обнаружения и выделения радиолокационных сигналов как достоверных источников оперативной информации о координатах и скорости движения анализируемых объектов, а также о местности, местных предметах, классах и пространственном расположении объектов гражданского и военного назначения выявляет необходимость высококачественного распознавания объекта радиолокационного изображения. Совершенствование и разработка новых образцов техники военного назначения, требует заметного повышения чувствительности, помехоустойчивости, разрешающей способности и точности определения координат и скоростей движения целей РЛС. Появилась необходимость совершенствования методов обнаружения и выделения сигналов из помех, а также изыскания новых методов и средств распознавания с учетом современной радиомаскировки объектов, включая вопросы прогнозирования радиолокационной заметности объектов сложной пространственной формы, использования новых диапазонов радиоволн и широкополосных импульсных сигналов. Значительные усилия ученых и инженеров направлены на оптимизацию методов обнаружения и защиты малоконтрастных объектов, а применительно к гражданской и военной технике возникает необходимость решения весьма сложной проблемы распознавания классов объектов военного назначения в режиме реального времени [1].

К современным системам радиосвязи предъявляется целый комплекс требований, затрагивающих различные аспекты их проектирования, производства и эксплуатации. К числу наиболее важных можно отнести скорость, дальность и надежность передачи данных, которые характеризуют потребительские свойства системы связи. Кроме того, важную роль играют такие показатели, как энергопотребление, занимаемая частотная полоса, массогабаритные параметры, стоимость и т.д. Одной из важных современных тенденций в развитии систем связи является широкое использование цифровых электронных компонентов, обеспечивающих цифровую обработку радиосигнала, начиная с определенного этапа его преобразования. Важным направлением развития беспроводных технологий связи является использование программно-зависимого радио (также SDR, Software-DefinedRadio).

Современные стандарты беспроводных коммуникаций требуют не только высокой производительности системы цифровой обработки сигнала, но и высокой степени интеграции компонентов, наличия таких модулей, как высокоскоростной приемопередатчик (для передачи данных по проводному интерфейсу), а также возможности простого обновления алгоритмов работы при смене протокола работы. Всем этим требованиям удовлетворяют системы на базе программируемых логических интегральных схем (ПЛИС) с архитектурой FPGA. Такие микросхемы содержат, кроме конфигурируемых логических ячеек, набор аппаратных модулей, реализующих операции, 
характерные для цифровой обработки сигналов и последующей передачи результатов в проводные сети: аппаратные блоки «умножение с накоплением», блочную память, высокоскоростные последовательные приемопередатчики.

C учетом повышения степени интеграции цифровых систем, оказывается возможным реализовать по технологии системы на кристалле (СНК) не только устройство обработки сигналов канального уровня, но и постобработку на уровне символов или пакетов данных. Для цифровой обработки сигналов характерно потоковое или массовопараллельное выполнение операций «умножение с накоплением», являющихся основой, в частности, КИХ-фильтров:

$$
y=\sum_{i=1}^{N} k_{i} x_{i}
$$

В представленном виде данная операция имеет прямое отображение на аппаратные ресурсы FPGA, в частности, реализуется без привлечения дополнительных компонентов блоками DSP48 в FPGAXilinx.

Дополнительно для постобработки символов можно использовать алгоритмы статистической обработки. В условиях наличия импульсных помех в канале связи более высокую помехоустойчивость демонстрируют статистические оценки, отличные от среднего арифметического - например, медиана и мода. Однако для определения таких оценок необходимо иметь в составе системы обработки радиосигнала вычислительные устройства с узлами, оптимизированными для выполнения специфичных статистической обработки операций.

Помехоустойчивая статистическая оценка может быть проведена по критерию, рассмотренному в [2]. В этой работе предлагается вычислять апостериорную вероятность гипотез по теореме Баейса, вводя переменную величину, характеризующую масштаб функции плотности распределения вероятности ошибки измерительного канала системы.

$$
\tau_{N}=n \frac{2(N-1) L}{c},
$$

где $\tau$ - введенный в [2] параметр «масштаб распределения плотности вероятности ошибки», варьируемый в предлагаемом методе статистической обработки.

В общем виде функционал качества приближения экспериментальных данных можно представить в виде:

$$
S(\beta, \sigma)=\sum_{i=1}^{N} \rho\left(y_{i}, f\left(x_{i}, \beta\right)\right),
$$

где $\rho$ - функция расстояния от экспериментальных точек до приближающей зависимости, определяемой параметрами $\beta$.

Формирование функции расстояния предлагается производить на основе функции распределения вероятности ошибки, характерной для измерительного устройства системы управления, как было показано в [3]. При использовании в качестве функции расстояния квадрата отклонения, при увеличении амплитуды выброса величина функционала качества приближения нарастает по параболическому закону, хотя ожидается, что такой отсчет должен оказывать ограниченное влияние на функционал качества.

Обработка измерительной информации согласно (2) подразумевает вычисление суммы условных вероятностей. Эти вероятности могут быть заданы таблично, т.е. реализованы в виде блока памяти. Аналогично, в виде блока памяти может быть реализовано устройство хранения результатов вычислений апостериорных вероятностей. 


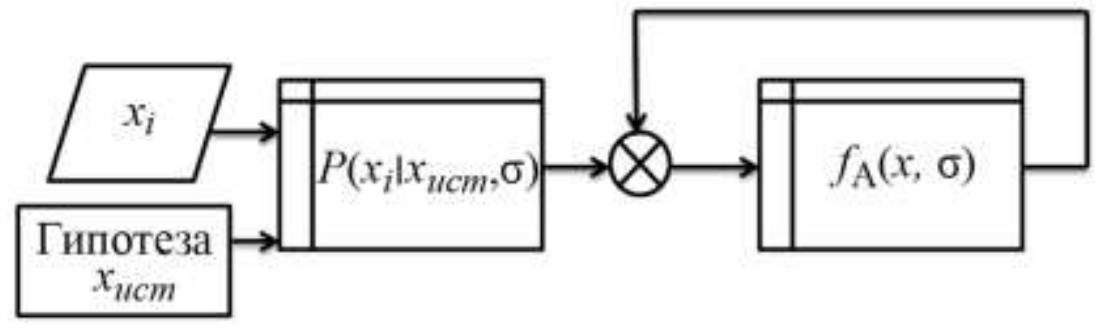

Рис.1. Блок-схема аппаратного ускорителя операций статистической обработки

На рис.1 представлена блок-схема устройства, представляющего собой аппаратный ускоритель операций статистической обработки, при этом можно видеть, что вычислительный узел не содержит блоков «умножение с накоплением». Таким образом, его применение в радиосистемах не приводит к дополнительным аппаратным затратам, однако повышает помехоустойчивость алгоритмов постобработки.

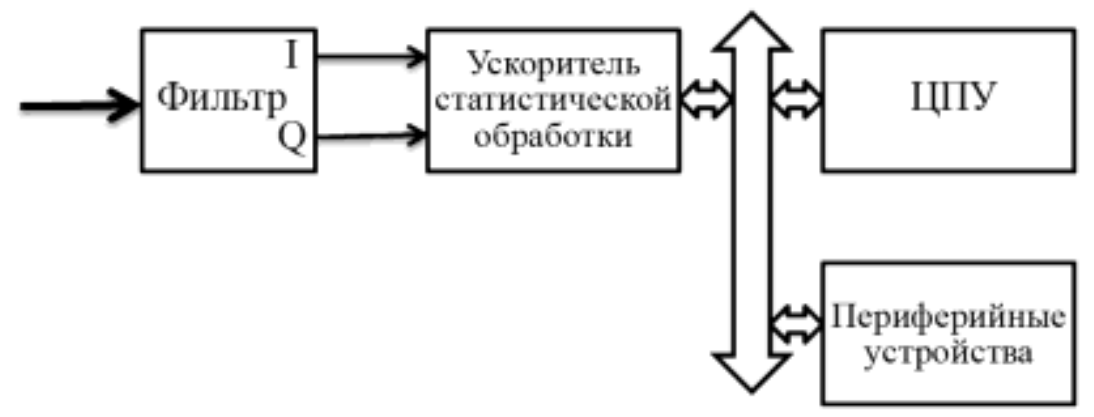

Рис.2. Структурная схема системы ичифровой обработки радиосигналов

Представленная на рис.2. структурная схема системы цифровой обработки радиосигналов, содержит аппаратный ускоритель статистической обработки. Элементы системы, показанной на рис.2, имеют различные требования к составу аппаратных средств. Если для фильтра используются в основном модули «умножение с накоплением», то аппаратный ускоритель статистической обработки использует преимущественно операции с памятью, поэтому оценка его производительности выполняется не по количеству операций «умножение с накоплением» в секунду, как для сигнальных процессоров, а по общей пропускной способности, реализованной в нем подсистемы памяти. Такой подход позволяет балансировать нагрузку на ресурсы ПЛИС. При этом центральный процессор такой системы не является основным элементом, определяющим ее функциональные характеристики или показатели производительности.

Рассмотренный подход использован для обработки сигналов эталонных стандартов частоты времени (ЭСЧВ). Для подстройки региональных ЭСЧВ используется система, основанная на сличении частоты подстраиваемого ЭСЧВ с государственным эталоном, сигнал которого передается на одной из известных частот.

В силу высокой стоимости ЭСЧВ задача измерения разности фаз является крайне актуальной, поэтому применение высокопроизводительной элементной базы для построения цифровой системы подстройки фазы представляется оправданным. Для решения этой задачи был разработан вычислительный комплекс на базе ПЛИС с архитектурой FPGA семейства Virtex-5 SXT. ПЛИС установлена на плате ML-605 производства Xilinx с дополнительной платой для ввода аналогового сигнала.

Для статистической обработки был применен метод приближения экспериментальных данных, основанных на оценке качества приближения в пространстве, формируемым на базе функции распределения вероятности ошибки используемой измерительной системы. В данном случае определялись параметры зависимости вида: 


$$
y(a, \sigma, C)=C \cdot e^{\frac{(x-a)^{2}}{2 \sigma^{2}}}
$$

В результате применения комплекса технических решений, включающих и оценку дисперсии распределения ошибки измерения фазы, было достигнуто существенное уменьшение (до 3 раз) среднего квадрата отклонения фазовых набегов разработанного цифрового приемника ЭСЧВ по сравнению с приемником-компаратором ПК Ч7-38.

\section{Заключение}

Использование высокопроизводительной элементной базы способно оказать комплексное положительное влияние на метрологические характеристики измерительных устройств, используемых для оценки параметров радиосигналов. При этом увеличение степени интеграции компонентов позволяет реализовать цифровое устройство класса СНК, сочетающее на одном кристалле устройства цифровой фильтрации, помехоустойчивой статистической обработки и центрального процессора общего назначения. Предложенный метод статистической обработки позволяет повысить помехоустойчивость системы обработки радиосигнала с использование компонентов и методов проектирования современной микроэлектронной промышленности.

$$
* * *
$$

1. Аксяитов М.Х., Егорова Е.В., Савич М.Ю., Рыбаков А.Н. Построение системы программнозависимой обработки данных на базе программируемых логических интегральных схем (ПЛИС) с архитектурой FPGA. Science public conference. X международная научно-практическая конференция «Научные тенденции: Вопросы точных и технических наук» (г.Санкт-Петербург, 2017г.). Секция: Технические науки. С.25-29.

2. Егорова Е.В., Тарасов И.Е. Математическое и программное обеспечение многопроцессорных вычислительных комплексов в задачах программно-зависимой обработки радиосигналов. Электромагнитные волны и электронные системы. №8. Т.17. 2012. С. 45-48

3. Фисенко В.Т., Фисенко Т.Ю. Компьютерная обработка и распознавание изображений: Учебное пособие. - СПб.: СПбГУ ИТМО. 2008. С.192.

\section{Вульфсон И.И. \\ Применение псевдорезонансов в машинах с реономными связями}

Санкт-Петербургский государственный университет промышленных технологий и дизайна

doi: $10.18411 / \mathrm{gdsn}-25-12-2019-03$

(Россия, Санкт-Петербург)

idsp: scienceconf-25-12-2019-03

\section{Вводные замечания}

Термины «псевдорезонанс» или «ложный» резонанс были предложены Я.Г.Пановко применительно к вынужденным колебаниям при быстром пересечении частотных диапазонов в резонансной зоне, чтобы амплитуда колебаний не успевала достичь максимальных значений [12,143]. Поясним это на простом примере линейной колебательной системы с одной степенью свободы, описываемой дифференциальным уравнением

$$
a \ddot{q}+b \dot{q}+c q=F_{0} \cos \omega t
$$

Поделив все члены уравнения (1) на $a$, запишем его в следующем виде:

$$
\begin{gathered}
\ddot{q}+2 n \dot{q}+k^{2} q=W_{0} \cos (\omega t-\gamma), \\
\text { где } b / a=2 n ; c / a=k^{2} ; \quad \mathrm{F}_{0} / \mathrm{a}=\mathrm{W}_{0} ; \gamma=\operatorname{arctg}\left[2 \mathrm{n} /\left(\mathrm{k}^{2}-\omega^{2}\right)\right] ;(0 \leq \gamma \leq \pi) .
\end{gathered}
$$


Сначала рассмотрим случай, когда отсутствует сила сопротивления $(b=0, n=0)$ . Решение складывается из решения однородного уравнения и частного решения неоднородного уравнения $Y$ :

$$
q=C_{1} \cos k t+C_{2} \sin k t+Y(t) .
$$

Зададимся начальными условиями $q(0)=q_{0}, \dot{q}(0)=\dot{q}_{0}$. Тогда $q_{0}=C_{1}+Y(0)$; $\dot{q}_{0}=C_{2} k+\dot{Y}(0)$ следовательно,

$$
q=\underbrace{q_{0} \cos k t+\frac{\dot{q}_{0}}{k} \sin k t}_{1}-\underbrace{Y(0) \cos k t-\frac{\dot{Y}(0)}{k} \sin k t}_{2}+Y(t) .
$$

Группа слагаемых 1 описывает свободные колебания, частота которых равна собственной частоте, а амплитуда зависит от начальных условий. Группа слагаемых 2 определяет так называемые сопровождающие колебания, частота которых также равна собственной частоте, но в отличие от свободных колебаний, амплитуда здесь не зависит от начальных условий, а определяется нарушением непрерывности частного решения $\mathrm{Y}$ и его производных [3,83]. Слагаемое 3 соответствует вынужденным колебаниям, зависящим как от параметров вынуждающей силы, так и от параметров колебательной системы.

При рассмотрении поведения системы в окрестности резонанса $(\omega=k)$ можно, не теряя общности, исключить из рассмотрения свободные колебания, приняв $q_{0}=0$, $\dot{q}_{0}=0$. В этом случае согласно формулы (4) получаем неопределенность, для раскрытия которой представим $q(t)$ в следующем виде:

$$
q=\frac{W_{0} t}{k+\omega} \frac{\sin [0,5(k-\omega) t]}{0,5(k-\omega) t} \sin [0,5(k+\omega) t]
$$

При $\omega \rightarrow k_{\text {получаем }} q=\left[W_{0} t /(2 k)\right] \sin (k t)$.

Таким образом, при отсутствии сил сопротивления резонансная амплитуда растет по линейному закону, поэтому при быстром пересечении резонансной зоны можно избежать аварийных последствий, т.е. возникает псевдорезонанс. Этот режим обычно реализуется при разгоне машины и в меньшей степени - при выбеге. При учете линейной силы сопротивления

$$
A=\frac{W_{0}}{\sqrt{\left(k^{2}-\omega^{2}\right)^{2}+4 n^{2} \omega^{2}}} .
$$

При резонансе $q=\left[W_{0} /(2 n \omega)\right] \sin (\omega t) ; A_{\max }=W_{0} /(2 n \omega)$.

\section{Динамический синтез}

При оптимизации динамических характеристик машин часто приходится анализировать системы с переменными параметрами, образующими реономные связи, которые являются источниками параметрических резонансов. Данной проблеме посвящен обширный объем научных работ, анализ которых здесь не приводится $[1,169 ; 2,59,323$; 3,$137 ; 4,331 ; 5,174 ; 6,103 ; 7,11$ и др.]. В отличие от псевдорезонансов при вынужденных колебаниях, рассмотренных выше, амплитуды параметрических резонансов возрастают очень интенсивно - по экспоненте. Это существенно усложняет реализацию быстрого пересечения соответствующих частотных диапазонов. Из множества практических задач 
в этой области мы обратимся здесь к мало изученной проблеме - оптимизации динамических характеристик при перемещении центра масс машин и механизмов $[8,12]$. Перемещение центра масс характерно для машин, осуществляющих перенос грузов, сельскохозяйственных машин, а также для многих технологических машин с неравномерным программным движением рабочих органов. В последнем случае при высоких скоростях машин, а также изменениях масс обрабатываемых изделий, это нередко существенно отражается на динамических характеристиках и реализации поставленных требований к качеству выпускаемой продукции. Кроме того, в зонах параметрических резонансов возникает опасность потери динамической устойчивости, когда уровень вносимой энергии превосходит энергию, отводимую диссипативными силами.

В качестве исходной базовой модели примем твердое тело, установленное на двух упругодиссипативных элементах (рис.1).

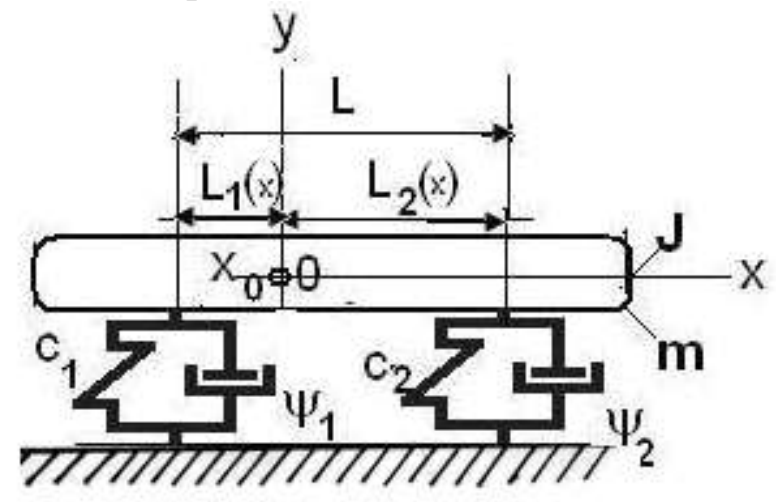

Рис.1. Динамическая модель: $c_{i}$ коэффициент жесткости; $\psi_{i}$-коэффициент рассеяния; $m$-масса; $J-$ момент инерциии.

Подобная модель при неподвижном центре масс была рассмотрена в работе [11,210] применительно к анализу колебаний автомобиля. Одно из существенных изменений этой модели, использованной Я.Г. Пановко, в данной статье связано с перемещением центра масс из-за переменных параметров колебательной системы, возникающих в цикловых машинах при движении звеньев механизмов и элементов технологических операций. Так как $x=x(\varphi) ; \varphi=\omega t$, в данной модели расстояния между центром масс и опорами оказываются переменными: $a=\left|L_{1}(t)\right| ; b=\left|L_{2}(t)\right|$ при $L_{1}(t)+L_{2}(t)=L=\mathrm{const}$. В цикловых механизмах связь между координатами на «входе» и «выходе» описывается нелинейной функцией положения П( $\left.{ }^{2}\right)[3,37 ; 5,12]$. Для идеального механизма, в котором отсутствуют зазоры и все звенья принимаются абсолютно жёсткими, $\varphi=\varphi_{*}=\omega t$. Пусть $\varphi=\varphi_{*}+q$, где q - динамическая ошибка, возникающая при колебаниях. Принимая во внимание, что функция положения непрерывна и дифференцируема, произведём линеаризацию этой функции в окрестности программного движения: $\Pi\left(\varphi_{*}+q\right) \approx \Pi\left(\varphi_{*}\right)+\Pi^{\prime}\left(\varphi_{*}\right) q, \quad$ где $\Pi^{\prime}=d \Pi / d \varphi \quad-$ первая передаточная функция механизма (аналог скорости). При этом расстояния между центром масс и опорами оказываются переменными: $\quad a=\left|L_{1}(t)\right| ; b=\left|L_{2}(t)\right| \quad$ при $L_{1}(t)+L_{2}(t)=L=\mathrm{const}$. Таким образом, при малых колебаниях, несоизмеримых с «идеальной» координатой практически без ущерба для точности мы заменили нелинейную связь нестационарной. Конкретизируем функции $L_{1}, L_{2}$ согласно следующим зависимостям (рис.2): 
$L_{1}(\varphi)=h(0,5+\lambda+\sigma \cos \varphi) ; L_{2}(\varphi)=h(0,5-\lambda-\sigma \cos \varphi) ;(\lambda+\sigma<0,5)$.
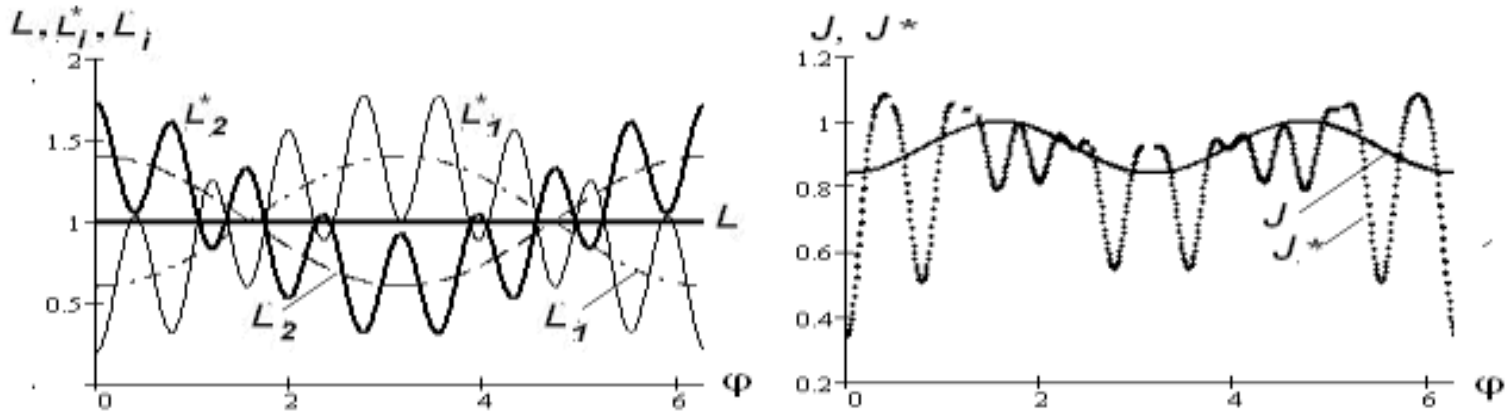

Рис.2. Графики $L_{i}(\varphi), L_{i}^{*}(\varphi), J(\varphi), J^{*}(\varphi)$

Здесь и ниже использован переход к безразмерному времени $\varphi=\omega t$, где $\omega$ угловая скорость. При этом реализуется переход к «безразмерным частотам» $\bar{k}_{i}=k_{i} / \omega$. (В целях упрощения формульного текста черточка над обозначением ниже будет опущена.) Параметры $\lambda$ и $\sigma$ соответствуют постоянной и переменной составляющим отклонения координаты центра масс от среднего положения. В современных технологических машинах возникает необходимость учета многочастотногного движения рабочего органа, когда приведенные инерционные и упругие характеристики содержат не только низкочастотные, но и высокочастотные составляющие [4-15]. Соответствующие параметры при частоте $j \omega$ на рис.2 и ниже выделены звездочкой: $L_{1}^{*}=L_{1}+r \cos j \varphi ; L_{2}^{*}=L_{2}+r \cos j \varphi$. При определении переменных собственных частот и колебательных режимов в качестве обобщенных координат примем вертикальное перемещение центра масс $y=q_{1}$ и угол поворота качающегося объекта $q_{2}$ с моментом инерции $J$ или $J^{*}$ (рис.3).

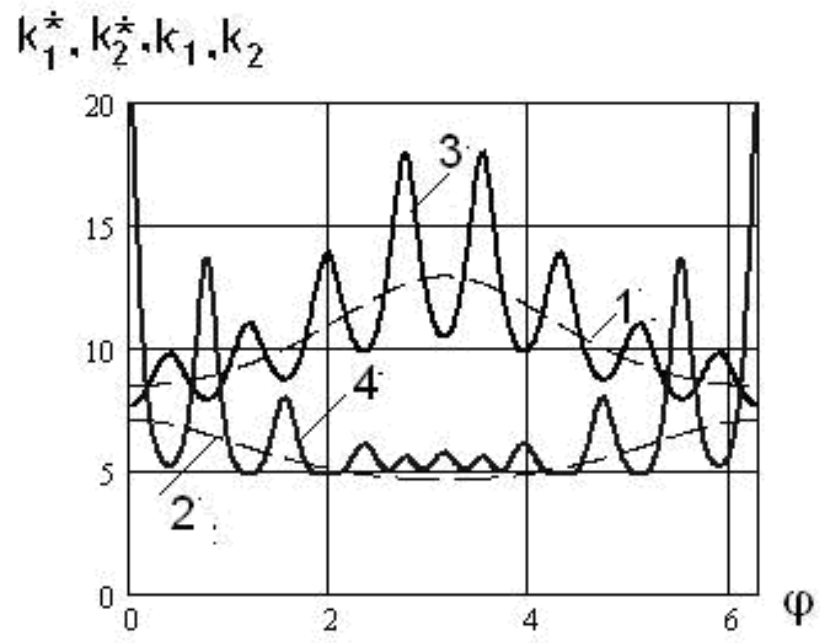

Рис.3. Собственнье частоты

Для определенности при численной оценке влияния переменности параметров примем $L=1_{\mathrm{M}}, \quad r=0,4 L, j=8, c_{1}=100 \mathrm{H} / \mathrm{M}, \quad \tilde{n}_{2}=30$ Нм. На рис.3 кривые 1 и 2 соответствуют среднеквадратическим частотным характеристикам, а кривые 3 и 4 переменным значениям, формирующим реономные связи. 
Рассматриваемая система описывается следующей системой дифференциальных уравнений:

$$
\left.\begin{array}{c}
m q_{1}^{\prime \prime}+2 \delta_{1}^{*} m k_{1}^{*} q_{1}^{\prime}+\left(c_{1}+c_{2}\right) q_{1}+\left(c_{1} L_{1}^{*}-c_{2} L_{2}^{*}\right) q_{2}=Q_{1} \\
\delta_{2}^{*} J^{*} k_{2}^{*} q_{2}^{\prime}+\left(c_{1} L_{1}^{*}-c_{2} L_{2}^{*}\right) q_{1}+\left(c_{1} L_{1}^{* 2}+c_{2} L_{2}^{* 2}\right) q_{2}=Q_{2}
\end{array}\right\}
$$

Здесь $Q_{1}, Q_{2}$ - обобщенные силы; $k_{1}^{*}(\varphi), k_{2}^{*}(\varphi)$ значения собственных частот; ()$^{\prime}=d / d \varphi ; \quad \delta_{i}^{*}=\vartheta_{i}^{*} /(2 \pi)_{-}$коэффициент демпфирования; $\vartheta_{i}^{*}-$ логарифмический декремент.

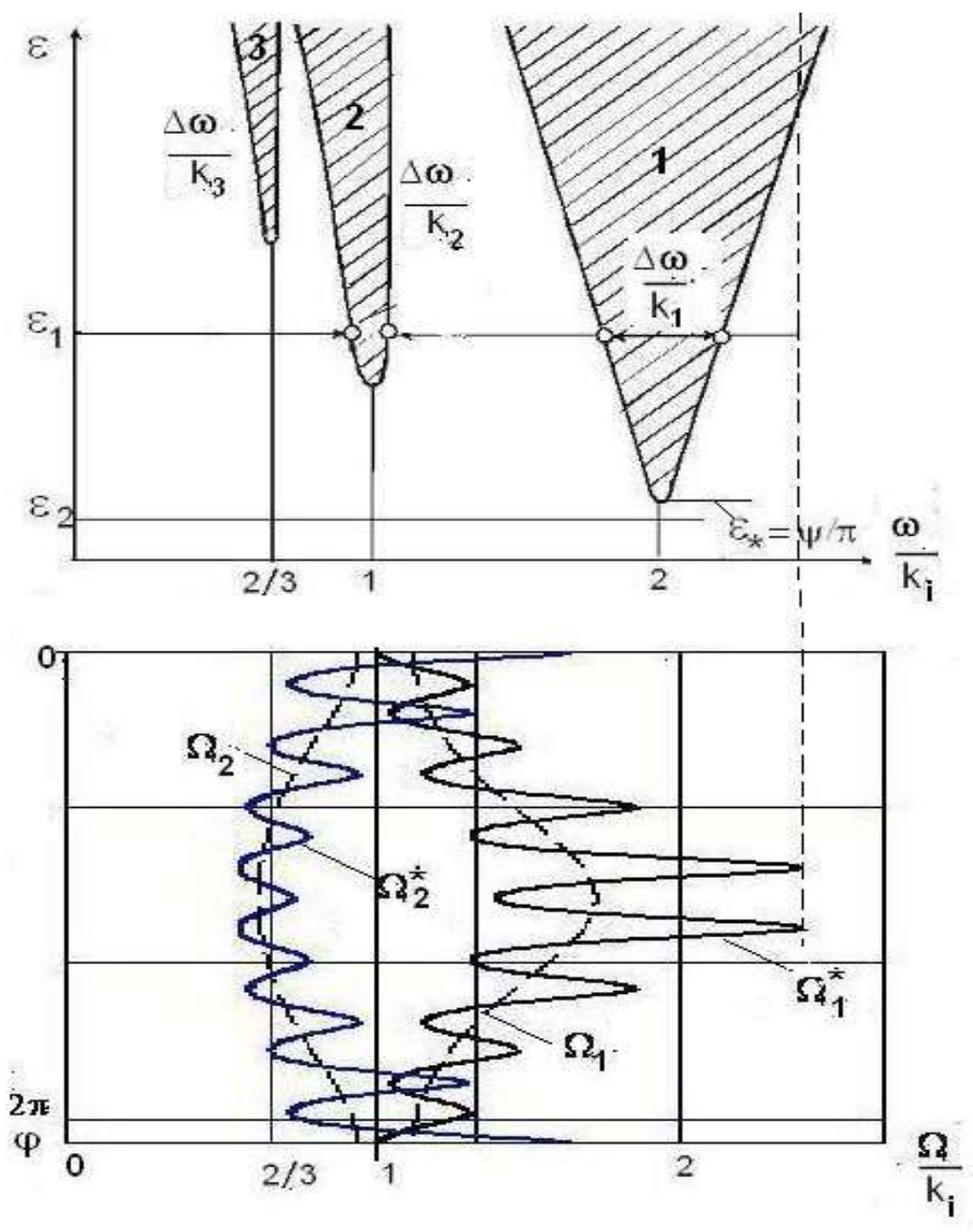

Рис. 4. К анализу динамической устойчивости

Графики, приведенные на рис.4, отображают связь между колебаниями, полученными при решении системы дифференциальных уравнений (7), и частотными диапазонами параметрических резонансов. Эта связь наглядно видна при совместном анализе обоих графиков. При этом использованы следующие условные обозначения: $\mathcal{E}_{-}$ глубина пульсации (коэффициент возбуждения [ 2,19] ); $\Omega_{i}, \Omega_{i}^{*}, \quad$ - частота параметрического резонанса; $\mathrm{i}=1,2, \ldots$ - номер резонанса, начиная с главного резонанса

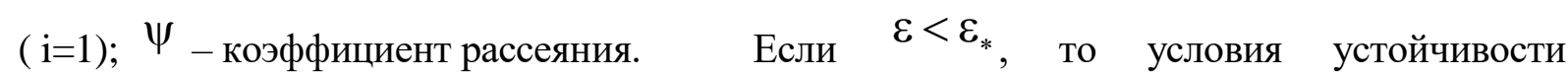
соблюдаются независимо от расположения области параметрического резонанса. В нашем случае это имеет место при $\varepsilon=\varepsilon_{2}$, а при $\varepsilon=\varepsilon_{1}$ происходит пересечение зон 
параметрического резонанса, что сопровождается интенсивным ростом амплитуд колебаний.

Нарушение условий динамической устойчивости в основном проявляется в зоне собственных частот $k_{2} ; k_{2}^{*}$ (рис.3,б). При определении полученных результатов была использована вторая теорема Ляпунова, определяющая достаточные условия асимптотической устойчивости, приведенная к виду $\quad \delta_{i}^{*}>-\left(k_{i}^{*}\right)^{\prime} /\left(2 k_{i}^{* 2}\right)$; $\delta_{i}>-k_{i}^{\prime} /\left(2 k_{i}^{2}\right)$. На графиках показаны границы, выделяющие зоны неустойчивости в зависимости от глубинны пульсации $\mathcal{\varepsilon}$ и критических значениях коэффициентов диссипации $\delta, \delta^{*}$ для главного параметрического резонанса и второй области возбуждения. Подавление резонанса достигается повышением диссипативных сил, однако при этом возникают нежелательные энергетические потери. В подобных случаях уместно использовать свойства псевдопараметрического резонанса. Обратимся к системе уравнений (7) без учета диссипации, что отвечает наиболее сильному условию возбуждения. На рис.5 при выбранных соотношениях переменных параметров приведены графики $q_{1}(\varphi), q_{2}(\varphi)$ и отображение колебаний на фазовой плоскости

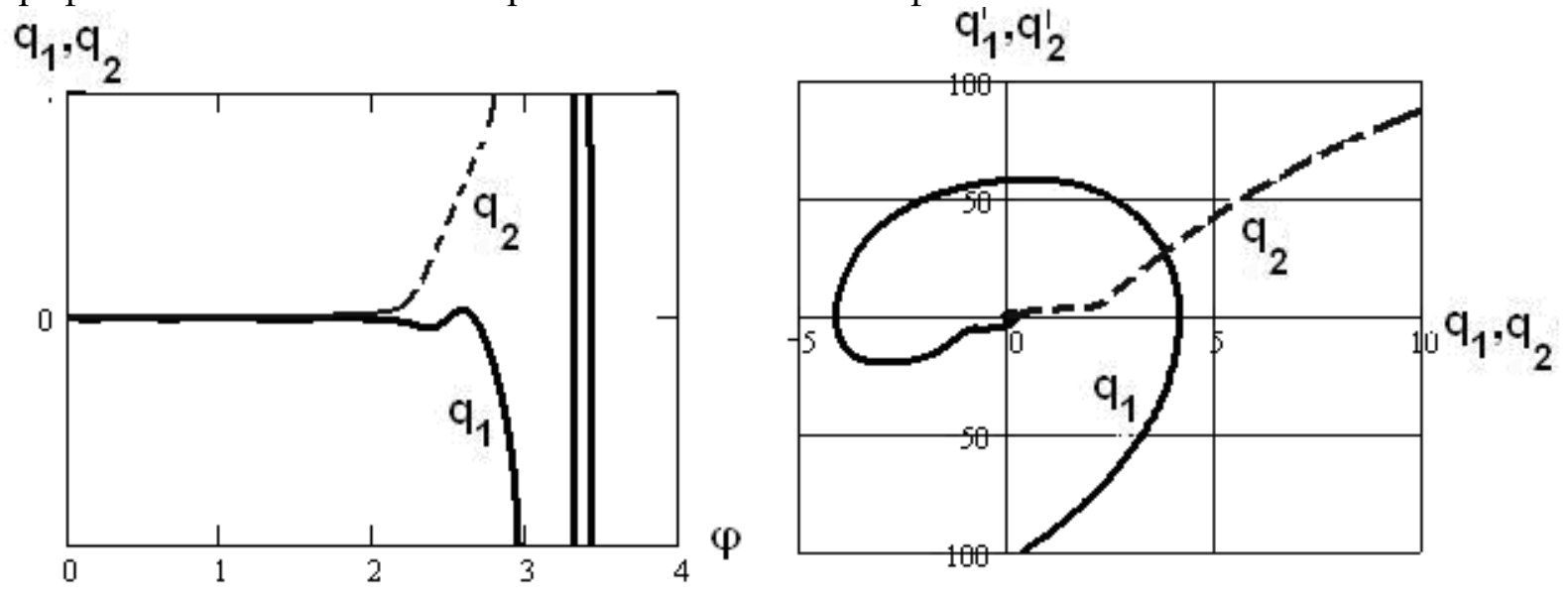

Рис.5. К анализу псевдорезонанса при параметрическом возбуждении

Полученные результаты на первый взгляд могут вызывать некоторое недоумение из-за возникновения задержки момента нарушения условий устойчивости на относительно длительном отрезке времени (см. первый график на рис.5). Как показал анализ, причиной данного эффекта является значительное уменьшение моментов инерции в этой зоне (см. рис.3,4), что привело к росту «собственных» частот, к «запаздыванию» входа в область главного параметрического резонанса и к возникновению динамической неустойчивости. При быстром пересечении этой области ( $\varphi \leq 2$ ) амплитуда параметрического резонанса обычно не достигает критического значения.

Заключение.

В статье решается задача, посвященная анализу виброактивности при возбуждении колебаний, вызванных перемещением центра масс машинного агрегата и возникающих при этом реономными связями. Важным результатом проведенного анализа является вывод, о появлении достаточно длительной задержки, предшествующей параметрическому возбуждению, что позволяет осуществить псевдорезонанс без увеличения диссипативных сил и тем самым устранить опасность динамической неустойчивости колебательной системы. От успешного решения поставленной задачи зависят производительность машины, точность воспроизведения заданных программных 
движений, непосредственно влияющих на качество выпускаемой продукции, долговечность и надежность оборудования, а также условия работы человека-оператора.

1. Бидерман В.Л. Теория механических колебаний. - М.: Высш. шк., 1980, 408 с.

2. Болотин В.В. Динамическая устойчивость упругих систем. М.: Гостехтеоретиздат, 1956.- 600 с.

3. Вульфсон И.И. Динамика машин. Колебания. - М.: Юрайт, 2017. - 275 с.

4. Вульфсон И.И. О колебаниях систем с параметрами, зависящими от времени. - Прикладная математика и механика1969. Т.33, №2. С. 331-337.

5. Вульфсон И.И. Динамика цикловых машин.-СПб.: Политехника. 2013. 425 с.

6. Dresig H., Vulfson I.I.: Dynamik der Mechanismen. - Springer, Wien, New York, 1989.- 328 S.

7. 7. Vulfson, I.I. Dynamics of cyclic machines. - Heidelberg, New York, Dordrecht, London: Springer, 2015. $410 \mathrm{p}$.

8. Вульфсон И.И. К проблеме снижения виброактивности технологических машин с реономными связями и близкими значениями парциальных частот механизмов. - Машиностроение и инженерное образование. 2019. №2.

9. Vulfson I.I. Exitation of parametric resonances in mechanisms with rheonomic constraints subject to the joint effect of fast and slow variations of parameters. Journal of Machinery Manufacture and Reliability. 2016. Vol. 45, No. 2. Pp. 95-103

10. Вульфсон. И.И., Коловский М.З. Нелинейные задачи динамики машин.- Л.:1968 Машиностроение $.1968 .284 \mathrm{c}$.

11. Пановко Я.Г., Губанова И.И. Устойчивость и колебания упругих систем. М.: Наука, 1967. -420 с.

12. Пановко Я. Г. Механика деформируемого твердого тела. М.: Наука, 1985. -287 с.

\section{Петров А.Л., Баева Л.С., Петрова Н.Е., Кумова Ж.В. Анализ композиционных материалов как элемента металлозамещения}

Мурманский государственный технический университет (Россия, Мурманск)

doi: $10.18411 / g d s n-25-12-2019-04$

idsp: scienceconf-25-12-2019-04

\section{Введение}

В состав композиционных материалов могут входить разнообразные элементы: черные, цветные металлы, сплавы, полимеры, керамические материалы. Существуют как классические композиционные материалы, так и поликомпонентные. Поликомпонентные композиционные материалы разделяются на полиматричные и гибридные. Полиматричные композиционные материалы включают в себя состав нескольких видов связующих. Гибридные композиционные материалы включают в себя состав нескольких видов наполнителей. Главная задача матрицы - обеспечение неразрушаемости материала и устойчивость к воздействию внешних факторов. Задача наполнителей - обеспечение совокупных механических свойств [1,2].

В производственной практике широко применяется создание готового изделия при изготовлении композиционных материалов. Применение подобных технологий может сказаться на готовой продукции как с положительной, так и с отрицательной стороны, с зависимости от изготавливаемого изделия.

Стоит заметить, что композиционные материалы не являются универсальными, при проектировании композиционного материала возможно задать необходимые механические свойства, которые будут в значительной мере превосходить традиционные материалы по одним параметрам, но уступать по другим. Следственно, проектировщику необходимо учитывать условия эксплуатации изделия, оптимальный состав и преобладающие свойства.

\section{Преимущества и недостатки композиционных материалов}

Главным преимуществом композиционных материалов является то, что имеется возможность создания материала и конструкции в одном производственном цикле.

Также к преимуществам можно отнести следующее: 
- $\quad$ высокая удельная прочность

- $\quad$ высокая жёсткость

- высокая износостойкость

- высокая усталостная прочность

- легкость

Главным недостатком композиционных материалов является высокая стоимость производства самого изделия и организация производственного участка [3].

Также к недостаткам можно отнести следующие характеристики:

- н низкая ударная вязкость

- высокий удельный объём

- гигроскопичность

- токсичность

- $\quad$ низкая эксплуатационная технологичность [4].

\section{Опыт проведения деформации образцов композиционных материалов}

В целях проведения научного исследования были представлены 2 образца композиционных материалов.

Фотографии исследуемых образцов № 1 и № 2 представлены на рисунке 1, структура образцов мелкозернистая.

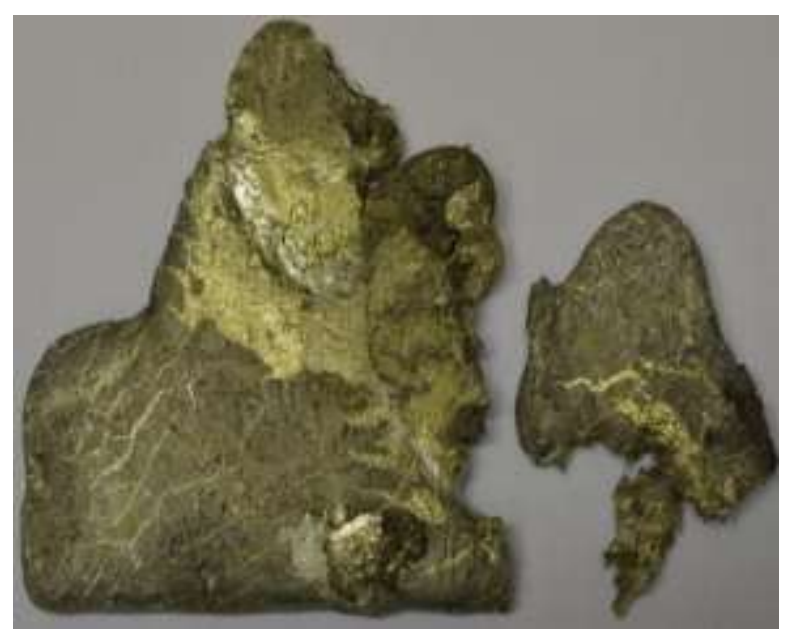

Образеи, № 1

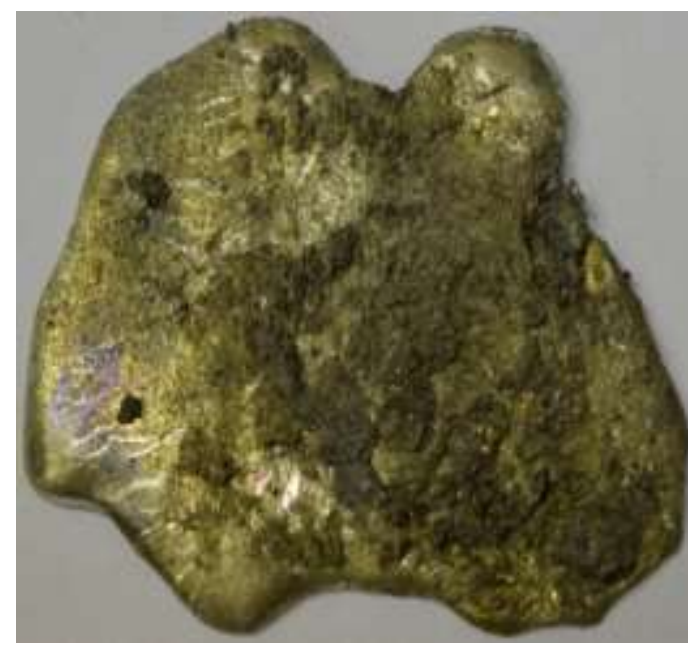

Образеи № 2

Рисунок 1. Внешний вид образиов композиционных материалов.

Геометрические размеры партии образцов композиционных материалов представлены в таблице 1.

Таблица 1

Геометрические размеры образиов композиционных материалов.

\begin{tabular}{|c|c|c|c|c|c|}
\hline $\begin{array}{c}\text { № } \\
\text { образца }\end{array}$ & $\begin{array}{c}\text { Геометрические } \\
\text { размеры, мм }\end{array}$ & Вес, г & Объем, см $^{3}$ & $\begin{array}{c}\text { Плотность, } \\
\text { Гсм }^{3} \mathrm{Al} / \mathrm{Mg}\end{array}$ & $\begin{array}{c}\text { Плотность, } \\
\mathrm{\Gamma}_{\mathrm{cm}}{ }^{3}\end{array}$ \\
\hline 1 & Неправильной формы & 48,39 & 6,3 & $2,6889 / 1,738$ & 7,608 \\
\hline 2 & Неправильной формы & 33,67 & 4,092 & $2,6889 / 1,738$ & 8,23 \\
\hline
\end{tabular}

Поверхность разрушения образцов №1 и №2 характеризуется наличием фасеток, имеющих слабо развитый микрорельеф и четкие границы. В данном случае разрушения фасетки межзеренные, образованные в результате разрушения по границам зерен: представляют собой многогранники, площадь их заметно меньше размеров зерен, поверхность межзеренных фасеток менее плоская, границами их являются ребра, образованные стыками граней зерен. 


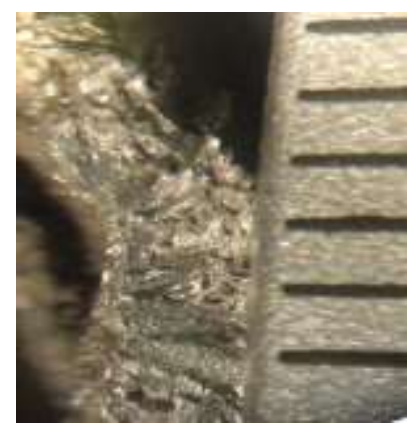

Образеи № 1

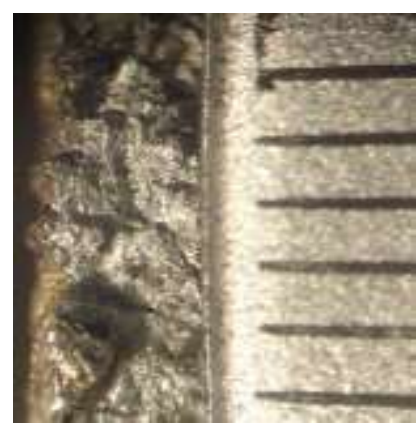

Образеи № 2

Рисунок 2. Вид поверхности излома со сколами образцов (увеличение х25).

Разрушение носит равномерный характер, изображенный на рисунках №1 и 2, что четко обнаруживается по контрасту совокупности гребней. Анализ особенностей микроразрушения свидетельствует о внутригранульном расслоении, которое независимо от прочности межгранульных границ может способствовать охрупчиванию композиции. Это соответствует уменьшению удлинения, но не снижает склонности к деформационному упрочнению.

Преимущественным видом микроразрушения исследуемых образцов №1 и №2 является образование трещин, излом со сколами.

Изгиб кристаллической решетки наблюдается в виде складок, гребней, бугров и впадин, занимающих участки внутри зерен или распространяющихся через несколько зерен. Образуется вследствие неоднородности протекания пластической деформации по объему композиционных материалов. Высота неровностей изменяется с увеличением степени деформации.

Наиболее распространенными являются методики проведения испытаний на смятие:

- ASTM E 238-84 (Reapproved 2008) «Standard Test Method for Pin-Type Bearing Test of Metallic Materials» для испытании ряда металлических материалов (алюминиевых, медных, магниевых, цинковых и бериллиевых сплавов) [5];

- $\quad$ ASTM D 5961/5961 M-01 «Standard Test Method for Bearing Response of Polymer Matrix Composite Laminates» для слоистых композиционных материалов с полимерной матрицей [6];

- ASTM D 953-02 «Standard Test Method for Bearing Strength of Plastics» для пластмасс [7].

В России национального стандарта для испытания на смятие не существует.

На примере установки ASTM D 5961/5961 M-01, изображенной на рисунке 3, была смоделирована схема испытания на смятие в модуле CODE-ASTER.

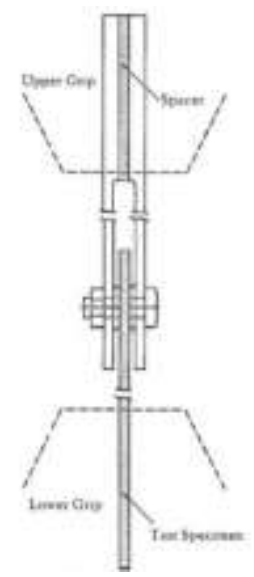

Рисунок 3. Установка для испытания на смятие по АSTM E 5961/5961 M-01 (вариант А). 
Положительным аспектом для испытания на смятие по ASTM E 5961/5961 M-01 являются фиксированные требования к размерам образца (для представленных материалов - 76x38.1x3.0 мм; LxBxH).

\section{Расчет прочности композиционных материалов}

Расчёт проведен в CAE Salome: модуль CODE-ASTER.

Согласно схеме приложения нагрузки, изображенной на рисунке 3 , к объектам исследований, в результате проведенных испытаний по указанному модулю максимальное напряжение, возникающее при изломе, составило:

образец №1 - $109 \mathrm{H} / \mathrm{Mm}^{2}$,

образец №2 - $148 \mathrm{H} / \mathrm{Mm}^{2}$.

Максимальное напряжение, возникающее при изломе отображено на рисунках 4 и 6.

Максимальное напряжение, возникающее при смятии, составило:

образец №1 - 61.8 H/Mм²,

образец №2 $-74.2 \mathrm{H} / \mathrm{Mm}^{2}$.

7.

Максимальное напряжение, возникающее при смятии отображено на рисунках 5 и

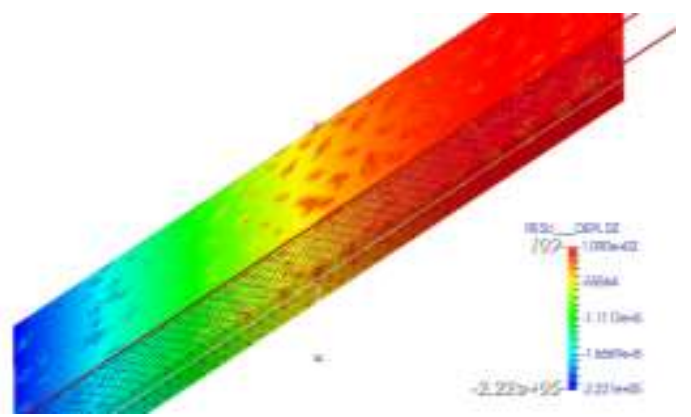

Рисунок 4. Спектрограмма распределения нагрузки при изломе образиа №1.

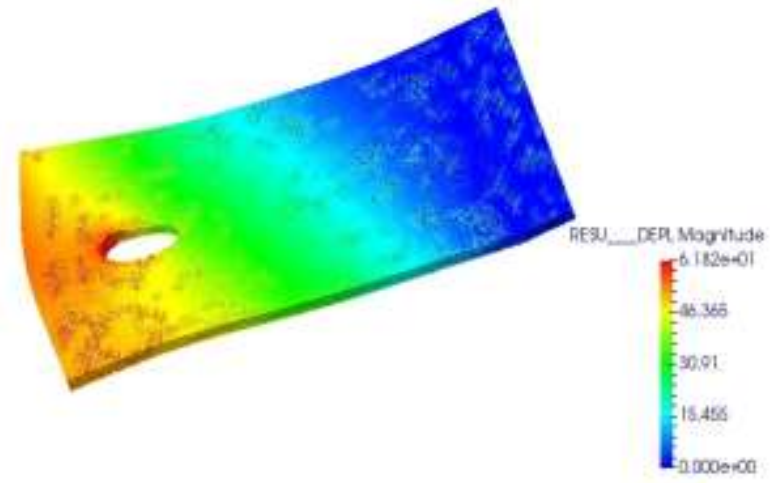

Рисунок 5. Спектрограмма распределения нагрузки при смятии образиа №1.

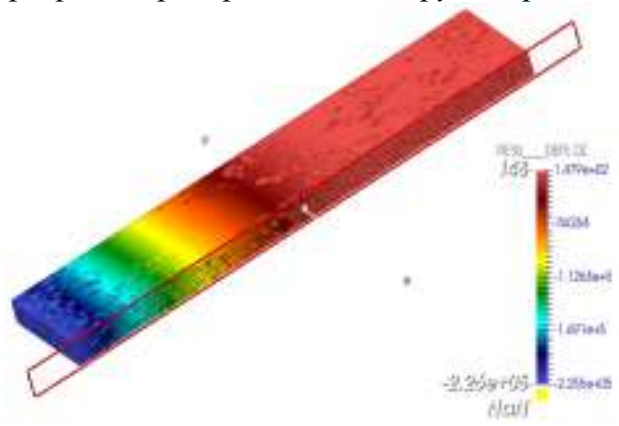

Рисунок 6. Спектрограмма распределения нагрузки при изломе образиа №2. 


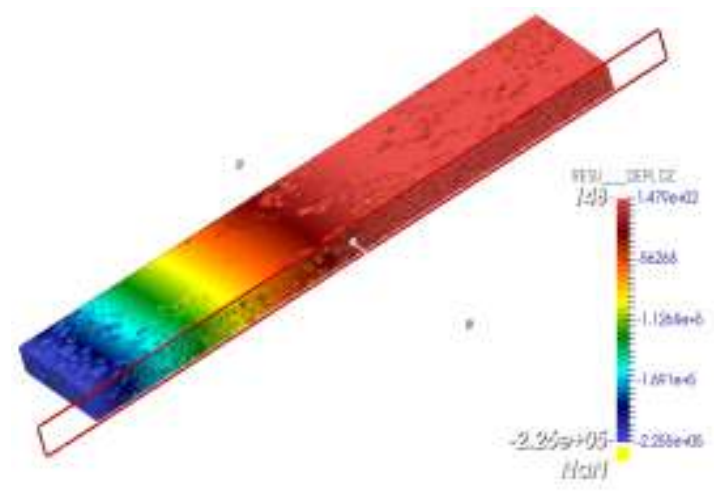

Рисунок 7. Спектрограмма распределения нагрузки при смятии образияа №2.

Результаты проведенных испытаний прочности представленных образцов по модулю программы CODE-ASTER для образца №1, представленного на рисунке 4, показали, что структура кристаллов при изломе - гексаэдрическая, для образца №2, представленного на рисунке 6, структура кристаллов - тетраэдрическая.

В таблице 2 представлены средние значения прочностных свойств исследуемых материалов.

Таблица 2

Средние значения прочностных свойств исследуемых материалов.

\begin{tabular}{|c|c|c|c|c|c|}
\hline $\begin{array}{c}\text { № } \\
\text { образца }\end{array}$ & $\begin{array}{c}\text { Твердость Роквелл } \\
\text { HRB }\end{array}$ & $\begin{array}{c}\text { Твердость } \\
\text { Бринель НВ }\end{array}$ & $\begin{array}{c}\text { Предел } \\
\text { прочности } \sigma_{\mathrm{B}}\end{array}$ & $\begin{array}{c}\text { Предел текучести } \\
\sigma_{02}\end{array}$ & $\begin{array}{c}\text { Плотность } \rho, \\
\Gamma^{2} \mathrm{~cm}^{3}\end{array}$ \\
\hline \multirow{3}{*}{1} & 38 & 73 & 21,097 & 18,09783 & \multirow{3}{*}{7,608} \\
\hline & 25 & 64 & 18,496 & 15,85714 & \\
\hline & 42 & 76 & 21,964 & 18,92045 & \\
\hline \multirow{3}{*}{2} & 15 & 59 & 17,051 & 14,47826 & \multirow{3}{*}{8,23} \\
\hline & 42 & 76 & 21,964 & 18,92045 & \\
\hline & 45 & 79 & 22,831 & 19,58824 & \\
\hline
\end{tabular}

\section{Заключение}

Применение композиционных материалов при изготовлении продукции очень актуально в наши дни. Судостроение не является единственной отраслью, где используют этот инновационный материал [8].

В настоящее время многие научные центры по всему миру активно экспериментируют с композиционными материалами. Главной целью является создание более практичных в производстве, следовательно, более экономичных материалов [9].

Уникальные свойства композиционных материалов позволяют изготавливать высокопрочные, легкие корпуса маломерных судов, подводных крыльев и многое другое. Обширно практикуется изготовление спасательных шлюпок для танкеров [10].

Повышенная коррозионная стойкость, способность сопротивления ударным нагрузкам, высокое качество поверхности и привлекательный внешний вид позволили композиционным материалам получить практическое применение во всех отраслях, в том числе и в судостроении. Следовательно, можно сделать вывод, что композиционные материалы являются материалами, которые, в перспективе, будут активно исследоваться и найдут более широкое применение в будущем.

$$
* * *
$$

1. Аналитический отчет. Использование композитных конструкционных материалов при создании пл. ЦКБ МТ «Рубин». Выпуск 18, март 2014 - 210 с.

2. Бобович, Б. Б. Неметаллические конструкционные материалы: учебное пособие. - М. : МГИУ, 2009 $384 \mathrm{c.}$ 
3. Композиционные материалы: Справочник / В. В. Васильев, В. Д. Протасов, В. В. Болотин и [др.]; Под общ. ред. В. В. Васильева, Ю. М. Тарнопольского. - М. : Машиностроение, $1990-512$ с.

4. Свойства углепластиков и области их применения / Б. И. Молчанов, М. М. Гудимов // ВИАМ, 1996

5. ASTM E238 - 84(2008) Standard Test Method for Pin-Type Bearing Test of Metallic. Materials. Catalogue of standards. Available from: https://catalogue.normdocs.ru/?type=card\&cid=com.normdocs.astm.card.e23884.2008 [Access 15th March 2019]

6. ASTM D5961 / D5961M - 17 Standard Test Method for Bearing Response of Polymer Matrix. Composite Laminates. Catalogue of standards. Available from: https://catalogue.normdocs.ru/?type=card\&cid=com.normdocs.astm.card.d5961.d5961m-17 [Access 15th March 2019]

7. ASTM D953-02 Standard Test Method for Bearing Strength of Plastics. Catalogue of standards. Available from: https://catalogue.normdocs.ru/?type=card\&cid=com.normdocs.astm.card.d953-0 [Access 15th March 2019]

8. Shubin, S.N., Freidin, A.B., Akulichev, A.G. Elastomer composites based on filler with negative thermal expansion coefficient in sealing application (2016) Archive of Applied Mechanics, 86 (1-2), pp. 351-360. https://www.scopus.com/inward/record.uri?eid=2-s2.0-84958772491\&doi=10.1007\%2fs0 0419-016-1120 1\&partnerID=40\&md5=4478c8d0a3735b90838ab5b6c7a4a0bc DOI: 10.1007/s00419-016-1120-1

9. Dmitrievskii, A.N., Komkov, N.I., Krotova, M.V., Romantsov, V.S. Strategic alternatives of import substitution of power equipment for the oil-and-gas sector (2016) Studies on Russian Economic Development, 27 (1), pp. 21-33. https://www.scopus.com/inward/record.uri?eid=2-s2.0$84961664670 \&$ doi $=10.1134 \% 2$

fS1075700716010020\&partnerID=40\&md5=443cfcd842f40994b990bcab52b39d6d $10.1134 / \mathrm{S} 1075700716010020$

10. Гуменюк Н. С., Грушин С. С. Применение композитных материалов в судостроении //Современные наукоёмкие технологии. - 2013 - № 8-1. - С. 116-117.

\title{
Boyarineva I.V. ${ }^{1}$, Khamagaeva I.S. ${ }^{2}$ Development of technology for a new bacterial concentrate
}

\author{
${ }^{1}$ Khabarovsk State University of Economics and Law \\ (Russia, Khabarovsk) \\ ${ }^{2}$ East Siberia State University of Technology and Management
} (Russia, Ulan-Ude)

doi: $10.18411 / g d s n-25-12-2019-05$

idsp: scienceconf-25-12-2019-05

\section{Abstract}

Rye and rye-wheat bread for centuries occupies a special place in the diet of the peoples of Russia. These baked goods have not only with what incomparable taste and aroma, but also, due to the peculiarities of the chemical composition of rye flour, have a positive impact on human health. Unfortunately, in recent years in our country and abroad, there is a tendency reducing the specific consumption of rye and rye-wheat bread. There is no doubt that only the continuous improvement of the technology of preparation of these products, providing a high quality of finished products in the processing of raw materials unstable, they can return to its former popularity [1].

Rye flour proteins in amino acid composition similar to proteins of wheat flour, but have higher content of essential amino acids - lysine, arginine, and threonine. An essential feature of rye proteins is their ability to rapidly and extensively swell. A significant part of this protein in the swells beyond all bounds, going into a state of viscous colloidal solution. Feature protein rye flour is also that they can not, despite the presence of gliadin and glutenin, to the formation of gluten. Due to the absence of gluten rye dough devoid of elasticity but has high viscosity. In rye dough is relatively a lot of water-soluble substances and free of moisture. Rye easily gelatinized starch and hydrolyzed more attack amylolytic enzymes than starch flour.

The rye flour is always a certain amount of $\alpha$-amylase in the active state, which, acting on starch, dextrin breaks it up. Dextrins give crumb stickiness zaminaemost and soggy [2].

Acidity rye dough in order to brake action $\alpha$-amylase at a level necessary to maintain significantly higher than in the wheat dough. Rye dough should have the acidity $(10-12)^{\circ} \mathrm{N}$ 
(degrees Neumann), so it is prepared to leaven, which is a continuous and consumable parts for the new revolving stage.

In the production of rye bread is the main fermentation lactic acid, and alcohol is a byproduct. The causative agent is the yeast of alcohol. In the absence of oxygen by a single energy for the life of the yeast cells is a fermentation of carbohydrates to form as the end products carbon dioxide and alcohol [3]. These processes are carried out through a series of intermediate reactions involving many enzymes. Homofermentative bacteria ferment glucose by glycolytic pathway Embden-Meyengofa and heterofermentative bacteria on the pentose phosphate pathway.

This article presents the results of studies on the development of the technology of the liquid bacterial concentrate for bread production. This bacterial concentrate is made up of a consortium of microorganisms typical for rye sourdough fermentation microflora. Analysis of experimental data shows that the concentrate has a high symbiotic sourdough fermentation activity, a good lift and contains a high titer of mesophilic lactic acid bacteria and yeast, not fermenting lactose.

Keywords: leaven, the leaven of the concentrate symbiotic consortium, a breeding ground biomass.

\section{Introduction}

Currently, manufacturing processes, based on the activity of microorganisms, have acquired a special significance. Modern biotechnology is inextricably linked with the use of new approaches to the creation and selection of new microorganisms, which entails an increase in the diversity of biotechnology products [4].

One of the most important tasks is to improve the production of biologics culture techniques (cells, viruses and bacteria) using domestic equipment and taking into account the qualitative characteristics of the product [5].

A necessary stage in the preparation of nutritive and protective medium, serum enzymes in the production of viral vaccines and bacterial preparations are their purification, separation and concentration, sterilization. The choice of methods for their implementation is a complex task and depends on the quality characteristics of the liquid [6].

Exclusive role in the production of a bacterial concentrate plays a nutrient medium. Proper selection of the composition of the culture medium allows the isolation of microorganisms from their habitats, preparation of pure cultures to study their morphology and biochemical characteristics, enables us to obtain the biomass of beneficial microorganisms. The main goal in the selection of the growth medium of any microorganism is to create a balanced blend of essential nutrients in such concentrations that will best growth.

As the needs of micro-organisms are very diverse, you can not create a universal medium for the optimal growth of all microorganisms. There are a variety of composition and technique of cooking medium. They are used all sorts of natural and artificial substrates, ranging from plain tap water and saline solutions to complex extracts from embryos of animals and plants from the waste (manure) to complete proteins of humans and animals.

For reproduction of any bacteria (regardless of purpose), you must provide a suitable biophysical environment. Skillful handling of biophysical and biological factors of particular importance in getting the accumulation of cultures and subsequent isolation of bacteria in the form of a pure culture. Temperature, aeration and the pressure determined by the conditions of cultivation. All of these factors affect the growth rate, biomass yield, metabolism and chemical composition of the bacteria.

The next process is the concentration of biomass. Concentration of the biomass is a process of dehydration - removing water contained in the substance in the free unbound state. Depending on the degree of humidity, density substances, particulate size, technological 
requirements in the microbiological industry use different methods of dehydration. These include filtration, centrifugation, coagulation, etc.

The use of membrane methods of purification, separation and concentration allows you to create environmentally friendly, energy-efficient production processes [7].

Due to the fact that the activity and stability of the concentrate of lactic acid bacteria cells is determined by age, a great importance is rapid isolation of cells from the culture medium or cooling it before cell isolation. When used as a culture medium of milk, whey, hydrolyzed milk, the cells are separated from the medium by centrifugation.

Thus, obtaining a bacterial concentrate is dependent on many factors and requires the researcher to specific knowledge and skills [8].

The existing technology of preparation of rye bread from a rye-wheat breads involves the use of traditional thick and liquid starters bred on pure cultures of microorganisms for the threephase circuit razvodochnogo cycle and supported by the continuous periodic refreshments. This technology is too long, time-consuming for the small bakeries power bakeries working in 1-2 shifts.

In this regard, the current is concentrated leaven creating high biotechnological properties, the use of which will intensify fermentation processes and considerably simplify the technology of preparation of rye bread.

Based on the above, it was determined objective of this work - using a mechanism heterofermentative fermentation kefir fungal leaven, to develop the technology of a bacterial concentrate for bread production.

\section{Objects and methods of study}

Experimental studies were carried out at the department "Technology of dairy products. Commodity and examination of goods "in the problem research laboratory of the East Siberian State University of Technology and Management. The object of research served as a fungal kefir starter. The morphology of the flora of the leaven of study by preparing preparations stained with methylene blue and Gram followed microcopying in an immersion lens system 90 with the application of drops of cedar oil. Number of lactose yeast were determined on potato glucose agar by limiting dilution. The amount of yeast fermenting lactose is not determined on the potato sucrose agar by limiting dilution. Total yeast in yeast was determined by limiting dilution, followed by inoculation in a Petri dish with Sabouraud medium. The number of mesophilic and thermophilic account lactobacilli were carried out on the medium "Baktofok".

\section{Results and discussion}

The most important factor in determining the course of biochemical processes in the rye leaven and the dough is the species composition of microflora.

The species composition of acid-forming bacteria in the rye leaven divided into two groups: homofermentative and heterofermentative lactobacilli. The main representatives are L.plantarum, L.delbruckii, L.casei. From heterofermentative widely used L.brevis, L.fermenti, L.bucheri, L.pastorianus.

According to many researchers, the use of homofermentative lactic acid bacteria alone does not provide good quality bread, heterofermentative bacteria are not only acidifier, but vigorous blowing, plays a significant role in the loosening of rye dough.

As a result of the accumulation of lactic acid, specific for rye dough of acid during prolonged culture almost completely displace no specific flora flour.

Kefir fungal microflora ferment is durable symbiosis consisting of homo- and heterofermentative lactic acid bacteria, yeast, and non-fermentable lactose fermenting, Acetobacter, etc.

In the process of the growth of yeast enriched environment near extracellular products of their metabolism, lactic acid bacteria used for its development. In turn, the growth of yeast cells is promoted by high acidity produced by lactic acid bacteria and enriching it, nitrogen compounds, due to the action of proteolytic enzymes of lactobacilli. 
Kefir fungi possess the unique ability to self-regulation of the composition of the microflora under the influence of various external factors (nutrient medium, temperature, aeration mode, the $\mathrm{pH}$ of the medium). Therefore, by changing the conditions of their cultivation can be carried out selective breeding microflora.

The possibility of obtaining a symbiotic starters for bakery production by adjusting the conditions autoselection kefir fungus to ferment the tea leaves from rye flour. It was found that at a temperature of cultivation $(30 \pm 1){ }^{\circ} \mathrm{C}$ activates the growth of yeast and heterofermentative lactobacilli flora typical of baking sourdough. It was found that symbiotic yeast has a high biological activity and stability of the composition of the microflora [9].

The studies optimized nutrient medium for bacterial concentrate symbiotic starters, taking into account the balanced growth of mesophilic lactic acid bacteria and yeast, not fermenting lactose. To build symbiotic ferment biomass determined the optimal dose of inoculum $5 \%$ of the volume of the medium. It is proved that the introduction to the culture medium $15 \%$ potato broth and $0.8 \%$ agar accelerates the growth of yeast and provides a high yield of biomass symbiotic leaven [10].

The experimental data allowed us to develop technology to produce liquid bacterial concentrate symbiotic starters. The technological process of the concentrate consists of the following stages: preparation of sourdough, cooking potato broth, cooking the culture medium, increasing biomass symbiotic starters, the separation of the liquid from the suspension culture cells, centrifugation, filling, capping, labeling and storage.

Environment for biomass symbiotic starters is cottage cheese whey with the addition of buffer salts and growth factors. Serum was previously clarified. For this purpose, it is heated to a temperature of $92-95^{\circ} \mathrm{C}$, perekislyayut $40 \%$ sodium hydroxide solution, allowed to stand for 10-15 min and filtered.

The prepared serum make potato broth, sodium citrate, potassium phosphate, magnesium sulfate, sucrose, ascorbic acid, agar and adjusted the $\mathrm{pH}$ to within 6.0-6.5.

Component composition of the culture medium shown in Table 1.

Table 1

The composition of the components of the culture medium for biomass symbiotic starters

\begin{tabular}{|l|c|}
\hline Name of raw materials and basic materials & Flowrate \\
\hline Serum curd & $850 \mathrm{ml}$ \\
\hline Potato Broth & $150 \mathrm{ml}$ \\
\hline Sodium citrate trisodium & $1,0 \mathrm{~g} / 1$ \\
\hline Potassium phosphate monobasic & $0,5 \mathrm{~g} / 1$ \\
\hline Magnesium sulphate & $0,1 \mathrm{~g} / \mathrm{l}$ \\
\hline Ascorbic acid & $0,1 \mathrm{~g} / 1$ \\
\hline Agar Microbiology & $0,8 \mathrm{~g} / 1$ \\
\hline Saccharose & $0,5 \mathrm{~g} / \mathrm{l}$ \\
\hline
\end{tabular}

The finished medium is sterilized at a temperature of $(121 \pm 1)^{\circ} \mathrm{C}$ for $30-40$ minutes, then cooled to a temperature $(30 \pm 2)^{\circ} \mathrm{C}$.

Cooking potato decoction is conducted as follows: peeled and sliced potatoes weighing $200 \mathrm{~g}$ is poured 1 liter distilled water and boiled for 1 hour. The broth was filtered, the filtrate was added water to the original volume, adjusted to $\mathrm{pH}=3.5$; bottled and sterilized at $121^{\circ} \mathrm{C}$ for 10 minutes.

The chilled to a temperature $(30 \pm 1)^{\circ} \mathrm{C}$ medium making potato broth in an amount of $15 \%$, followed by the inoculum in an amount of $5 \%$ by weight of medium. Medium with inoculum thoroughly mixed and neutralized to a $\mathrm{pH}$ value of 6.0-6.5.

Artificial symbiotic ferment biomass is carried out under batch culture with twice medium neutralization and stirring at 12 and 24 hours of culture. The duration of cultivation is 24 \pm 2 hours at a temperature of $(30 \pm 1)^{\circ} \mathrm{C}$ (Figure 1). 


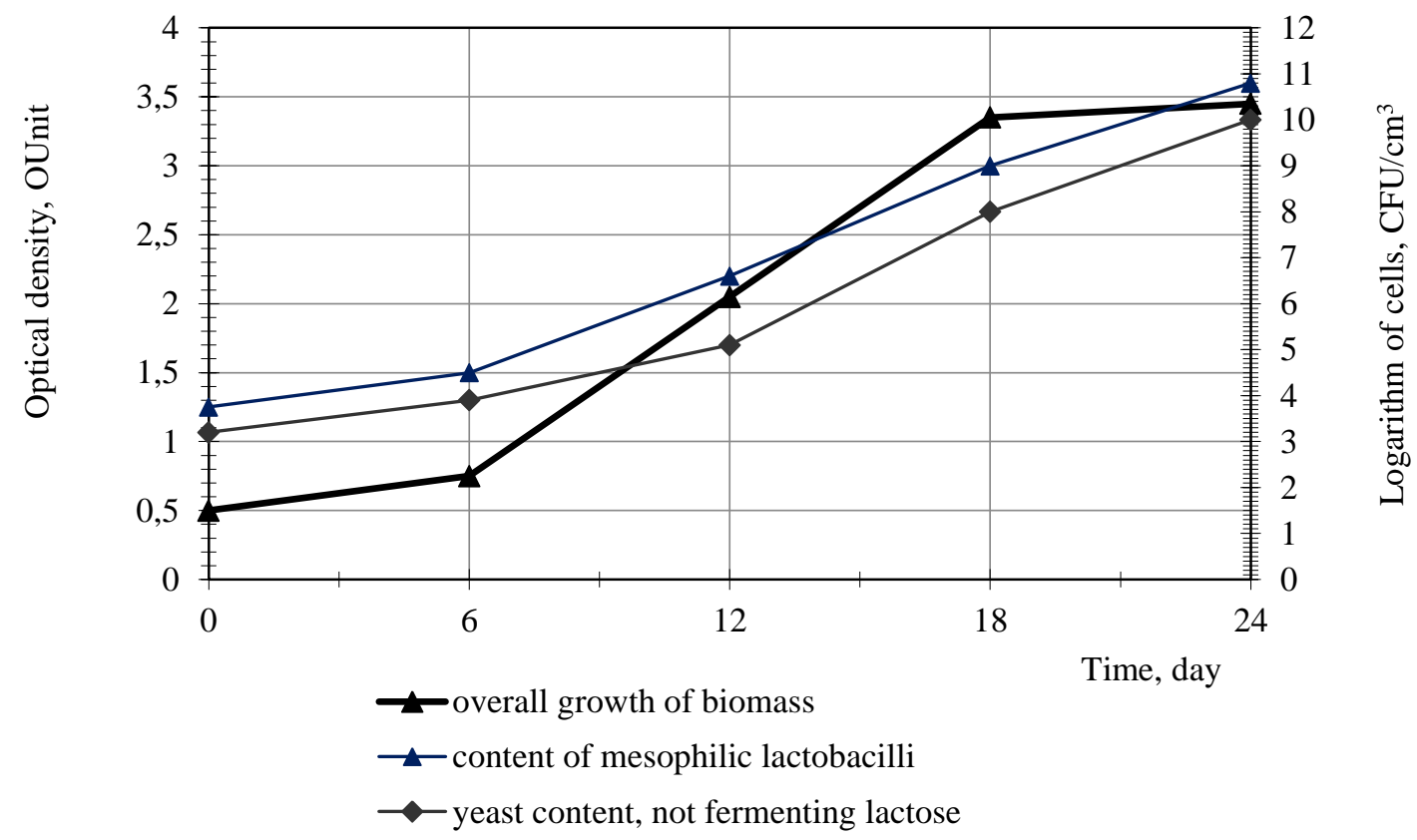

Fig. (1). - Effect of culture conditions on the growth of biomass and quantitative content of mesophilic lactic acid bacteria and yeast, not fermenting lactose

After completion of culturing fused upper layer was separated whey remaining biomass was cooled to a temperature $(5 \pm 3)^{\circ} \mathrm{C}$ and centrifuged at $3500 \mathrm{rpm}$ the frequency of $\mathrm{v} / \mathrm{c}$, time 15 minutes. The cell suspension was separated from the culture fluid concentrate dispensed into sterile vials feeders $2 \pm 0.15 \mathrm{~cm} 3$, vials sealed with rubber stoppers and aluminum caps roll.

Quality indicators bacterial concentrate are presented in Table 2.

Table 1

Qualitative characteristics of the concentrate symbiotic starters

\begin{tabular}{|c|c|}
\hline Indicator & Characteristics \\
\hline The consistency and appearance & Homogeneous, allowed separation of serum \\
\hline Colour & From white to light yellow \\
\hline The active acidity, $\mathrm{pH}$ & $5,5-7,0$ \\
\hline Number of mesophilic lactobacilli, C.F.U./.cm ${ }^{3}$, no less & $1 \times 10^{10}$ \\
\hline The amount of yeast no fermenting lactose, C.F.U./. $\mathrm{cm}^{3}$, no less & $1 \times 10^{10}$ \\
\hline $\begin{array}{l}\text { Product Volume }\left(\mathrm{cm}^{3}\right) \text {, which is not allowed: } \\
\text { - Coliform bacteria (coliforms) } \\
\text { - S. aureus } \\
\text { - pathogens (including Salmonella) }\end{array}$ & $\begin{array}{l}10 \\
10 \\
50\end{array}$ \\
\hline Mildew, C.F.U./ $/ \mathrm{cm}^{3}$, no more & 10 \\
\hline
\end{tabular}

As seen from Table 2, the bacterial concentrate is characterized by high titer of viable cells of mesophilic lactobacilli and yeasts not fermenting lactose.

\section{Conclusion}

The process for producing leaven symbiotic bacteria concentrate has a number of advantages to the known manufacturing methods for producing sourdough of rye bread:

- for biomass used in cooking simple and cheap nutrient medium based on cheese whey;

- $\quad$ as inoculum used symbiotic starters, close to a natural sourdough for rye bread;

- thanks to the balanced composition of the medium intensifies the process of accumulation of biomass;

- microbial biomass is characterized by high titer of viable cells.

The peculiarity of the proposed technical solution is a fundamentally new approach to the preparation of the inoculum and biomass symbiotic starters. Particular attention in the 
manufacture of symbiotic concentrate was paid to the optimization of culture medium, and the creation of conditions for the growth of mesophilic lactic acid bacteria and yeast fermenting lactose is not characteristic of the fermentative microflora used in baking production.

Thus, the developed technology for producing bacterial symbiotic ferment concentrate provides the ability to eliminate semi-continuous cultivation in production without requiring additional factors to sustain activity and reducing the costs of raw materials.

$$
\text { *** }
$$

1. Black I.V. Perfection of rye and rye-wheat bread based on the optimization of biotechnological properties of semi-finished test .: Author. Dis. cand. tehn. Science / Moscow, 2009. - 187 p.

2. Kozmina N.P. Biochemistry bakery. - M.: Food Industry, 1978. -440 p.

3. Brusilovsky L.P. Process control cultivation of starter cultures and dairy products. - M.: Light and food industries, 1982. $-127 \mathrm{p}$.

4. Botina S.G. Molecular biological approaches to the selection of bacterial cultures to create ferments for biotechnology: Author. Dis. Dr. is biological. Sciences. - Moscow, 2011. - 46 p.

5. Popova V.M. Development and improvement of biotechnological processes in industrial production of biological products: Author. Dis. Dr. is biological. Sciences. - Schyolkovo, 2011. - 46 p.

6. Tikhonov I.V. Biotechnology // I.V. Tikhonov, E.A. Ruban, Gryazneva T.N., Samujlenko A.Y., Gavrilov V.A. Ed. Acad. RAAS ES Voronin. - SPb .: GIORD, 2005. - 792 p.

7. Guslavsky A.I. High-performance machines for the separation, purification and concentration of liquid systems and new biotechnological processes on their basis. Author. diss. Doctor. tehn. Science, Shchyolkovo. $-2007 .-55 \mathrm{p}$.

8. Pridannikova I., Elizarova E. A. New generation of starter cultures in the development of technology of dairy products // Dairy Industry, 2003. - №9. - s. 32-33.

9. Boyarineva I.V., Hamagaeva I.S. Development symbiotic starters for bakery production // Herald ESSTU. 2014. - №6. - s. 101-107.

10. Boyarineva I.V., Hamagaeva I.S. Investigation of culture conditions the symbiotic microflora of sourdough for bakery production // Herald ESSTU. - 2015. - №2. - s. 74-80.

\section{Tsarev T.A. \\ Practical use of opportunities of the center of youth innovative creativity in Karelia}

Petrozavodsk State University (Russia, Petrozavodsk)

doi: $10.18411 / g d s n-25-12-2019-06$

idsp: scienceconf-25-12-2019-06

\section{Abstract}

There are presented the information about Youth Innovation Creation Centre by Petrozavodsk State University in Petrozavodsk city. It is shown the purposes, equipment of modern appliances and possibilities. There are expositions of some real results that young people receive on its base.

Key words: innovations, teaching, 3D-printing, program-lathes.

\section{Introduction}

The project to create the Center for Youth Innovative Creativity (CYIC) was initiated in 2012 by the executive director of the All-Russian public organization Young Innovative Russia A. Bukhalo and approved by the Supervisory Board of the Agency for Strategic Initiatives.

Since 2012, the project on the creation of CYIC has been introduced (realized) as part of the State Support Program for Small and Medium Enterprises of the Russia Ministry of Economic Development. The priority is the non-commercial use of equipment by children and youth in order to acquire skills in working with high-tech equipment [1].

In various regions of the Russian Federation, more than 140 CYICs have been opened; new similar centers are continuing to open.

The requirements for CYIC are put forward, mainly by the presence of: 
- own or leased premises with an area of not more than 120 square meters for equipment;

- a standard set of equipment (3D printer, milling machine, laser cutting machine, cutting plotter, 3D scanner, + office equipment);

- a staff of at least two specialists who can work with the whole range of equipment and have experience working with children;

- Internet connection and Internet portal for access to a single FabLab network.

\section{Brief description of the Petrozavodsk LLC CYIC}

The Center "CYIC" LLC in Petrozavodsk was established with 100\% participation of Petrozavodsk State University (PetrSU) as a founder with the support of the Ministry of Economic Development of the Russian Federation and the Ministry of Youth, Physical Culture and Sports of the Karelia Republic in accordance with agreement of July 13, 2016 No. 051-MB16 within the framework of the "Support and development of small and medium-sized enterprises engaged in socially significant activities" measure [2].

The basis for the creation of CYIC was the FabLab model - fabrication laboratory, the "production laboratory", first developed by Neil Gershenfeld - Center for Bits and Atoms (CBA) in MIT (USA) [3].

CYIC is located at 58 A. Nevsky Ave. in the building of IL-GiSN (Institute of Forest Mountain and Construction Sciences).

The main objectives of CYIC are the following:

- Ensuring of the children and youth access to modern equipment of direct digital production for the implementation, verification and commercialization of their innovative ideas;

- Support for innovative creativity of children and youth, including for the purpose of the professional implementation and self-employment of youth business undertakings;

- Technical and industrial support of children and youth, small and medium-sized businesses involved in the development of promising types of products and technologies;

- Interaction, exchange of experience with other centers of youth innovative creativity in the Russian Federation and abroad;

- Organization of conferences, seminars, working meetings, etc.

- Creation of a database of users of the Center for Youth Innovation Creativity;

- Conducting regular training events and the implementation of training programs in order to assimilation of the capabilities of equipment by users of CYIC.

The main users of CYIC are students, schoolchildren, applicants, small and mediumsized businesses.

CYIC is equipped with diverse modern equipment that allows to perform many production operations:

- 3D printer Picaso 3D Designer PRO 250;

- 3D scanner Shining 3D EinScan-Pro;

- $\quad$ Laser station KamachII 1510;

- Cutting plotter Mimaki CG-60SRIII;

- The milling machine with ChPU Kamach 1325W;

- Digital oscilloscope Agilent MSOX2022A;

- Machine turning and milling Metal Master MML 2870 M;

- Multimeter digital desktop Keysight 34450A;

- Digital multimeter Fluke 17B +;

- Digital multimeter Fluke 107;

- Soldering station digital Hakko FR-802 / Hakko FX-951;

- Soldering station Lukey-852D +; 
- Stereoscopic microscope Altami PS.

The presence of this equipment allows CYIC not only to provide training for young people, but also to produce various products on order. On the Kamach II 1510 laser machine, stencils are cut out, nameplates, tablets, signs and souvenirs are engraved. Kamach $1325 \mathrm{~W}$ milling machine copes with thick sheets of plywood that are not suitable for laser cutting, as well as engraving three-dimensional objects from wood billets. And the Russian-made Designer PRO 250 two-extruder 3D printer prints complex plastic models, from prototypes of engineering parts to foundry molds.

The following materials and consumables are used: wood (including plywood, veneer, chipboard, MDF), TESA film for engraving, acrylic, ALUMAMARK, aluminum for engraving, anodized aluminum, brass steel, decorative overlays, PVC foam, polystyrene, PET, automatic transmission, ABS, leather.

Workers attribute not only high-quality materials to their advantages, but also speed of execution, reasonable prices and an individual approach to the customer.

\section{Examples of the implementation of the CYIC tasks in Petrozavodsk}

In 2018 the author has passed production and pre-diploma practices on the basis of the enterprise "CYIC" LLC at PetrSU, during which it was possible not only to get acquainted with the impressive possibilities of modern production equipment, but also to implement the project for final qualification certificate [4]. As a result, a much deeper understanding of the design of virtual enterprises, their functioning and planned standard products has appeared. This type of training was incredibly useful, which was noted by supervisors as well as by the certificate commission.

The future masters of Forest, Geology and Building Institute are received practical skills in the Center at 2019 year. Also, the finalists of the UMNIK contest in 2018 (Fund for the Promotion of Innovations) are provided with a site and equipment for the design of products, including this opportunity is provided to the author of this article.

\section{Conclusion}

In general, it can be noted that the idea of CYIC at PetrSU successfully works, which is confirmed by the following:

1. The center helps youth in the implementation of scientific projects.

2. He is self-sufficient at the expense of commercial orders.

3. Self-sufficiency allows him to engage in his core business - to be a platform for youth creativity, material and technical, economic, information and social basis for the formation, development, preparation for independent activities of small innovative enterprises, commercialization of scientific knowledge and high technology.

$$
* * *
$$

1. WORLD // Young Innovative Russia - URL: https://i-innomir.ru/projects/1, free. - (09/19/2019)

2. CYIC Petrozavodsk // Center for Youth Innovative Creativity - URL: https://cmit10.ru/about/, free. $(12 / 10 / 2019)$

3. TED Ideas worth spreading // Neil Gershenfeld about Fab Labs - URL: https://www.ted.com/talks/neil_gershenfeld_on_fab_labs/transcript?language=en\#t-21422, free. $(10 / 16 / 2019)$

4. Tsarev T.A. Design of a workshop for single and small-scale products from wood and wood materials on CNC machines. Graduation work. Petrozavodsk: Petrozavodsk State University, 2018.151 s. 
РАЗДЕЛ ІІІ. МЕДИЦИНА

\section{Ахундова А.A. \\ Функциональное состояние почек у новорожденных с задержкой внутриутробного развития}

Азербайджанский Медицинский Университет (Азербайджан, Баку)

doi: $10.18411 / g d s n-25-12-2019-07$

idsp: scienceconf-25-12-2019-07

Известно, что нарушение адаптационно-гомеостатических функций фетоплацентарного комплекса может вызвать изменения внутриутробного состояния плода, его гипоксию и формирование синдрома задержки внутриутробного развития [1].

Задержка внутриутробного развития (ЗВУР) - это системное нарушение созревания и развития всех органов и систем ребенка, поэтому постнатально ЗВУР может проявиться недостаточностью функции любого органа или системы, в том числе почек у новорожденного ребенка[2].

Как известно, новорожденные с ЗВУР, вследствие воздействия различных патологических факторов, пребывают в состоянии хронической внутриутробной гипоксии. Это означает, что фактор гипоксии воздействует на них более длительный период, и приводит к ожидаемым результатам. Согласно Manalich R. Et al., у детей с задержкой развития при рождении бывает меньшее число нефронов, что приводит к гипертрофии и гиперфильтрации резидуальных нефронов. Почка, работающая в режиме гиперфильтрации, на фоне других патологических состояний, вкупе с хронической гипоксией и асфиксией, бывает более уязвима к действию различных патологических факторов [3].

Цель исследования - изучение функционального состояния почек у новорожденных, родившихся с ЗВУР.

Материалы и методы исследования. Клинико-лабораторное обследование было проведено у 81 новорожденных. Из них 33 новорожденных были с ЗВУР, 20 доношенных новорожденных перенесших асфиксию в родах, и 28 недоношенных новорожденных, соответствующие гестационному возрасту, из группы сравнения. Обследованные новорожденные дети были разделены на 3 группы: в 1-ю группу включены -15 доношенных новорожденных с ЗВУР (МГВ), и 20 доношенных новорожденных перенесших асфиксию. У всех детей данной группы гестационный возраст составлял 37 42 недель. 2-ю группу составили 13 недоношенных новорожденных, соответствующих гестационному возрасту (СГВ) и 8 новорожденных малых для гестационного возраста (МГВ). Срок гестации в этой группе составлял 33-36 недель. И в 3-ю группу вошли новорожденные с гестационным возрастом 29-32 недели, из них 15 недоношенных новорожденных соответствующих $Г$ В, и 10 недоношенных новорожденных с ЗВУР(МГВ).

Для изучения функционального статуса почек у новорожденных с ЗВУР, определяли мочевую концентрацию биомаркеров повреждения почки KIM-1 и NGAL, a также Цистатин С в плазме крови для определения гломерулярной фильтрации. Пробы мочи и крови для определения данных биомаркеров были собраны двухкратно в 1-3-й и 710-й дни жизни. Моча собиралась с 6:00 до 9:00 утра, забор образцов крови проводился в середине данного временного промежутка времени из периферических вен в количестве 2 миллилитров. 
Уровни биомаркеров определяли методом твердофазного иммуноферментного анализа (ИФА), NGAL с использованием набора реактивов компании «RayBiotech, İnc" (США), КіМ-1 - с использованием набора реактивов компании Arqutus Medical, Bio Assay Works, а Цистатин С в сыворотке крови с использованием набора реактивов «Нuman Cystatin C ELISA» фирмы «BioVendor» (Чехия).

Результаты и их обсуждение. При оценке состояния почек у новорожденных малых к гестационному возрасту установлено, что концентрация КIM-1 в этой подгруппе новорожденных на первые сутки жизни недостоверно превышает показатель подгруппы новорожденных, соответствующих гестационному возрасту. (Таблица 1)

Таблица 1

Уровень КіМ-1 в сравниваемых группах

\begin{tabular}{|c|c|c|c|c|c|c|}
\hline Показатель & Группа & $\begin{array}{c}\text { Групповые } \\
\text { показатели } \\
\text { среднее } \pm \delta\end{array}$ & $P$ & Подгруппы & $\begin{array}{c}\text { Групповые } \\
\text { показатели } \\
\text { среднее } \pm \delta\end{array}$ & $P$ \\
\hline \multirow{6}{*}{$\begin{array}{l}\text { КїМ-1, } \\
\text { 1-3 сутки }\end{array}$} & \multirow{2}{*}{1 -ая, $\mathrm{n}=35$} & \multirow{2}{*}{$1,12 \pm 0,135$} & \multirow{2}{*}{$*<0,001$} & $\mathrm{CГВ}, \mathrm{n}=20$ & $1,06 \pm 0,20$ & \multirow{2}{*}{$*_{-} 0,89$} \\
\hline & & & & МГВ, $\mathrm{n}=15$ & $1,19 \pm 0,14$ & \\
\hline & \multirow{2}{*}{2 -aя, $\mathrm{n}=21$} & \multirow{2}{*}{$1,015 \pm 0,113$} & \multirow{2}{*}{$\wedge^{\wedge} 0,653$} & $\mathrm{C} Г \mathrm{~B}, \mathrm{n}=13$ & $0,80 \pm 0,11$ & \multirow{2}{*}{$\wedge_{-} 0,2$} \\
\hline & & & & МГВ, $\mathrm{n}=8$ & $1,32 \pm 0,22$ & \\
\hline & \multirow{2}{*}{ 3-ья, $\mathrm{n}=25$} & \multirow{2}{*}{$0,837 \pm 0,125$} & \multirow{2}{*}{$\mathbb{q}<<0,001$} & $\mathrm{CГВ}, \mathrm{n}=15$ & $0,70 \pm 0,11$ & \multirow[b]{2}{*}{ 9|- 0,82} \\
\hline & & & & МГВ, $\mathrm{n}=10$ & $1,10 \pm 0,29$ & \\
\hline \multirow{6}{*}{$\begin{array}{l}\text { КїМ-1, } \\
\text { 7-10 сутки }\end{array}$} & \multirow{2}{*}{1 -ая, $\mathrm{n}=35$} & \multirow{2}{*}{$1,38 \pm 0,12$} & \multirow{2}{*}{$*_{-} 0,02$} & СГВ,n=20 & $0,70 \pm 0,076$ & \multirow{2}{*}{$*<0,001$} \\
\hline & & & & МГВ, $\mathrm{n}=15$ & $1,97 \pm 0,146$ & \\
\hline & \multirow{2}{*}{2 -ая, $\mathrm{n}=21$} & \multirow{2}{*}{$0,97 \pm 0,11$} & \multirow{2}{*}{$\wedge^{\wedge}-0,26$} & $\mathrm{CГВ}, \mathrm{n}=13$ & $0,84 \pm 0,17$ & \multirow{2}{*}{$\wedge-0,729$} \\
\hline & & & & МГВ, $\mathrm{n}=8$ & $1,11 \pm 0,125$ & \\
\hline & \multirow{2}{*}{ 3-ья, $\mathrm{n}=25$} & \multirow{2}{*}{$0,63 \pm 0,09$} & \multirow{2}{*}{$\mathbb{\Upsilon} \mid<0,001$} & СГВ, $\mathrm{n}=15$ & $0,56 \pm 0,08$ & \multirow{2}{*}{ 9- 0,906} \\
\hline & & & & МГВ, $\mathrm{n}=10$ & $0,88 \pm 0,22$ & \\
\hline
\end{tabular}

СГВ- соответствующие гестационному возрасту, МГВ- малье для гестациионного возраста

*-достоверность разнищы между подгруппами 1-ой группь

^-достоверность разнищь между подгруппами 2-ой группь

ף-достоверность разнищы между подгруппами 3-ьей группь

В динамике уровень этого маркера у СГВ новорожденных резко уменьшается, в то время как у новорожденных малых к гестационному возрасту остается на высоких цифрах, статистически значимо, превышая значения СГВ подгруппы. Полученные нами данные совпадают с результатами М. Комиановски и соавторов, демонстрирующих высокие значения KIM-1 в группе доношенных новорожденных с задержкой внутриутробного развития [4]

Во 2-ой и 3-ей группе уровень этого маркера в МГВ подгруппе, несмотря на некоторое снижение в динамике раннего неонатального периода недостоверно превышает таковой в СГВ подгруппе, как при 1-ом, так и при 2-ом измерении.

Анализ значений NGAL в моче свидетельствует в пользу более тяжелого поражения почек в группе глубоконедоношенных детей, имеющих наиболее высокие значения NGAL на 7-10 сутки жизни. Мочевая концентрация этого маркера у доношенных новорожденных к концу 1-ой недели жизни несколько ниже значений недоношенных детей, без достоверного характера этой разницы (Таблица 2). 
Таблища 2

Уровень иNGAL в сравниваемых группах

\begin{tabular}{|c|c|c|c|c|c|c|}
\hline Показатель & Группа & $\begin{array}{c}\text { Групповые } \\
\text { показатели } \\
\text { среднее } \pm \delta\end{array}$ & $\mathrm{P}$ & Подгруппы & $\begin{array}{c}\text { Групповые } \\
\text { показатели } \\
\text { среднее } \pm \delta\end{array}$ & $\mathrm{P}$ \\
\hline \multirow{6}{*}{$\begin{array}{l}\text { uNGAL } \\
1-3 \text { сутки }\end{array}$} & \multirow{2}{*}{1 -ая, $n=35$} & \multirow{2}{*}{$111,9 \pm 7,9$} & \multirow{2}{*}{$*_{-} 0,96$} & $\mathrm{CГВ}, \mathrm{n}=20$ & $129,9 \pm 15,7$ & \multirow[b]{2}{*}{$*_{-0,01}$} \\
\hline & & & & МГВ, $\mathrm{n}=15$ & $101,4 \pm 8,0$ & \\
\hline & \multirow{2}{*}{2 -aя, $n=21$} & \multirow{2}{*}{$131,9 \pm 12,0$} & \multirow{2}{*}{$\wedge-0,96$} & $\mathrm{C} Г \mathrm{~B}, \mathrm{n}=13$ & $120,1 \pm 14,4$ & \multirow[b]{2}{*}{${ }^{\wedge}-0,04$} \\
\hline & & & & МГВ, $\mathrm{n}=8$ & $163,1 \pm 19,4$ & \\
\hline & \multirow{2}{*}{3 -ья, $\mathrm{n}=25$} & \multirow{2}{*}{$126,2 \pm 10,8$} & \multirow{2}{*}{ ๆ - 0,932 } & $\mathrm{CГВ}, \mathrm{n}=15$ & $109,2 \pm 15,7$ & \multirow[b]{2}{*}{ ๆ-0,03 } \\
\hline & & & & МГВ, $\mathrm{n}=10$ & $150,5 \pm 11,1$ & \\
\hline \multirow{6}{*}{$\begin{array}{c}\text { uNGAL } \\
\text { 7-10 сутки }\end{array}$} & \multirow{2}{*}{1 -aя, $\mathrm{n}=35$} & \multirow{2}{*}{$113,6 \pm 12,1$} & \multirow{2}{*}{$*-0,97$} & $\mathrm{C} Г \mathrm{~B}, \mathrm{n}=20$ & $149,5 \pm 27,9$ & \multirow[b]{2}{*}{$*_{-0,19}$} \\
\hline & & & & МГВ, $\mathrm{n}=15$ & $95,7 \pm 9,9$ & \\
\hline & \multirow{2}{*}{2 -ая, $\mathrm{n}=21$} & \multirow{2}{*}{$127,9 \pm 14,5$} & \multirow{2}{*}{$\wedge-0,963$} & $\mathrm{CГВ,} \mathrm{n}=13$ & $112,6 \pm 24,7$ & \multirow{2}{*}{$\wedge^{\wedge}-0,59$} \\
\hline & & & & МГВ, $\mathrm{n}=8$ & $151,5 \pm 16,4$ & \\
\hline & \multirow{2}{*}{3 -ья, $\mathrm{n}=25$} & \multirow{2}{*}{$145,1 \pm 10,7$} & \multirow{2}{*}{ ๆ $-0,82$} & $\mathrm{CГВ}, \mathrm{n}=15$ & $130,4 \pm 21,8$ & \multirow[b]{2}{*}{ १-0,962 } \\
\hline & & & & МГВ, $n=10$ & $169,8 \pm 4,0$ & \\
\hline
\end{tabular}

СГВ- соответствующие гестащиионному возрасту, МГВ- малье для гестациионого возраста

*-достоверность разницы между подгруппами 1-ой группь

^-достоверность разнииь между подгруппами 2-ой группь

9-достоверность разницы между подгруппами 3-ьей группь

Анализ мочевой концентрации NGAL в отличие от данных тех же авторов (Monika Kamianowska et al. ) показал, что данный показатель на 1-3 сутки жизни достоверно выше в подгруппе новорожденных, соответствующих гестационному возрасту в группе доношенных новорожденных, что по-видимому обусловлено зрелостью иммунной системы и адекватностью воспалительных реакции в ответ на перинатальный стресс ( Таб. 2) [4]. В противоположность доношенным в обеих подгруппах недоношенных новорожденных достоверно высокие значения NGAL выявлены у новорожденных с ЗВУР. К 7-10 суткам эта разница не имеет статистическую значимость. В литературе до настоящего времени отсутствуют сведения об уровне UNGAL y недоношенных новорожденных с ЗВУР, однако существуют сведения, свидетельствующие о зависимости высокой концентрации данного маркера в моче от массы тела у новорожденных с МГВ и низкой массой тела при рождении [5].

При оценке уровня Цистатина С в зависимости от гестационного возраста достоверных различий между уровнем этого показателя в крови на 1-3 сутки жизни мы не выявили. В динамике концентрация Цистатина С в крови у доношенных новорожденных имеет некоторую тенденцию к снижению, в группах детей, родившихся преждевременно, наоборот незначительное повышение. Хотя достоверно показатели 1-3-х и 7-10-х суток внутри групп не отличались, мы выявили статистически значимое различие в отношении уровня этого показателя между доношенными и недоношенными новорожденными на 710 сутки жизни (p1-2 =0,011-между 1-ой и 2-ой, p1-3=0,017 - между 1-ой и 3-ей группой). Сведения о содержании Цистатина $\mathrm{C}$, по данным различных исследователей носят неоднозначный характер. Так Li Y и соавторы также выявили зависимость плазменной концентрации данного вещества от гестационного возраста, тогда как результаты, полученные Cruzado и соавт. указывают, что повышение уровня этого маркера по мере снижения гестационного возраста не имело достоверного характера [6,7]. 
Таблицуа 3

Концентрации Цистатина С (мг/л) в моче у новорожденных с ЗВУР в зависимости от гестачионного возраста в динамике неонатального периода

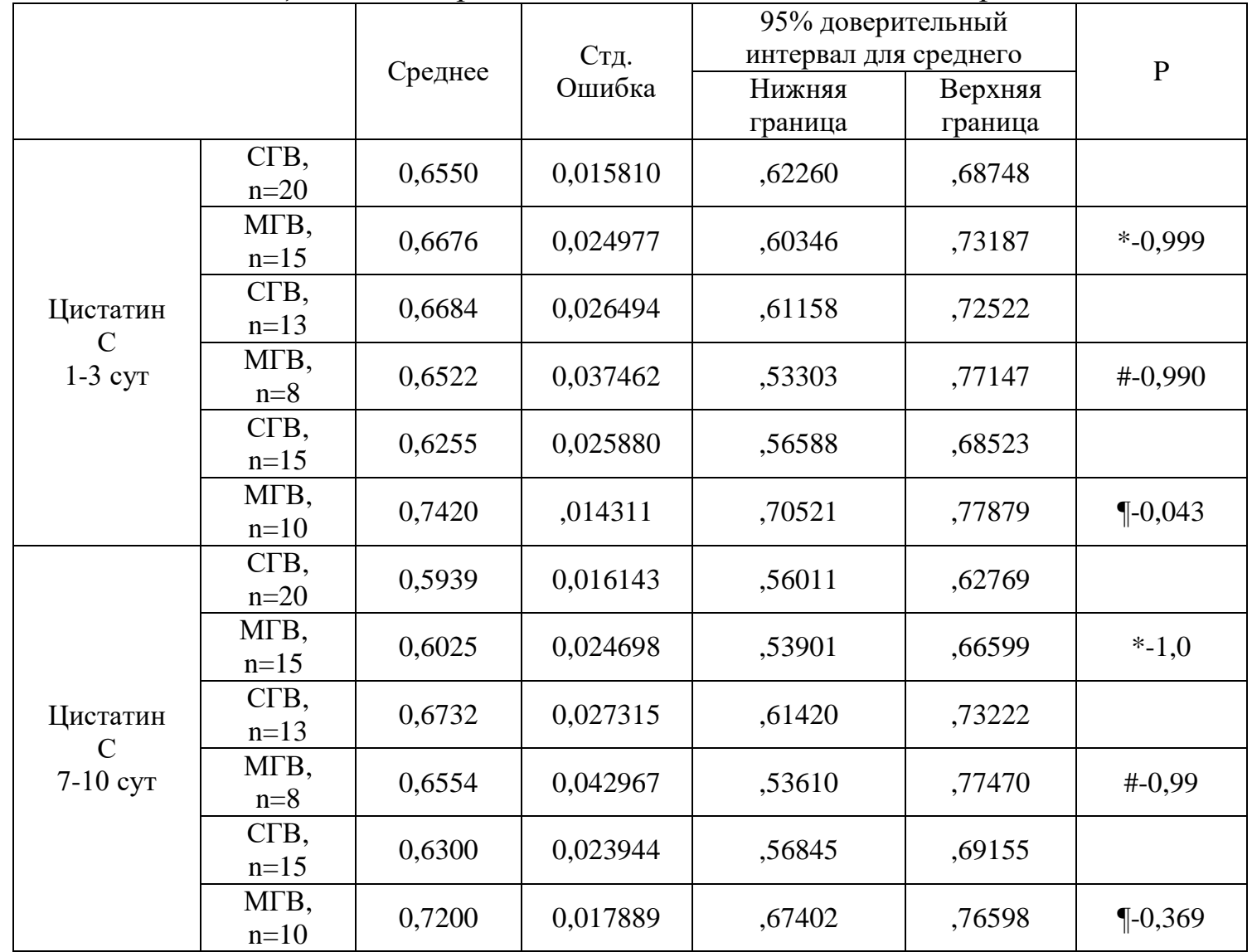

СГВ- соответствующие гестациионому возрасту, МГВ- малье для гестациионного возраста

*-достоверность разницы между подгруппами 1-ой группь

\#-достоверность разнищь между подгруппами 2-ой группьь

१-достоверность разницы между подгруппами 3-ьей группь

При сравнении уровня Цистатина С у новорожденных в зависимости от соответствия массы тела гестационному возрасту, достоверные отличия получены только лишь между подгруппами 3-ей группы. У новорожденных с ЗВУР уровень этого маркера, отражающего функциональный статус клубочков, статистически значимо превышает аналогичный показатель новорожденных, антропометрические данные соответствуют гестационному возрасту. Учитывая, что количество клубочков пропорционально массе тела новорожденного, полученные нами результаты являются вполне логичным. Отсутствие этой закономерности в 1-ой и 2-ой группе, по-видимому, обусловлено тем, что к 33-36 неделе внутриутробного развития, процесс образования новых нефронов завершается, что сопровождается увеличением функциональной емкости и резервных возможностей почек новорожденных (таблица 3).

Таким образом, результаты наших исследований позволяют предположить, что чем более выражена внутриутробная задержка развития, тем более происходит нарушение почечной функций у этих новорожденных, и использование биомаркеров почечного поражения- KIM-1, NGAL и Цистатин C для определения функционального статуса у недоношенных новорожденных и новорожденных с ЗВУР на ранней стадии ишемической нефропатии является целесообразным и позволяет нам наладить адекватное лечение и предотвратить развитие острой почечной недостаточности.

Выводы. Почки новорожденных с задержкой внутриутробного развития демонстрируют большую уязвимость тубулярного аппарата и клубочковой фильтрации 
почек по сравнению с недоношенными с массой, соответствующей гестационному возрасту, что подтверждает высокую чувствительность почек к неблагоприятным фактором антенатального периода, редуцирующим внутриутробно рост плода.

\section{$* * *$}

1. Sharma D., Shastri S., Sharma P. Intrauterine Growth Restriction: Antenatal and Postnatal Aspects. Clin Med Insights Pediatr. 2016; 10: 67-83.

2. Franco M. C. P., Oliveira V., Ponzio B., et al. Influence of Birth Weight on the Renal Development and Kidney Diseases in Adulthood: Experimental and Clinical EvidenceInt J Nephrol. 2012; 2012: 608025

3. Manalich R, Reyes L, Herrera M, Melendi C, Fundora I. Relationship between weight at birth and the number and size of renal glomeruli in humans: a histomorphometric study. Kidney International. 2000;58(2):770773.

4. Kamianowska M., et al. The Tubular Damage Markers: Neutrophil Gelatinase- Associated Lipocalin and Kidney Injury molecule-1 in newborns with Intrauterine Growth Restriction. // Neonatology 2019; 115:169174)

5. Cruzado B.L. et al. Serum Cystatin C level in preterm newborns in our setting.// Nefrologia. 2015;35(3):296303

6. Li Y., Fu C., Zhou X. [et al] Urine interleukin-18 and cystatin-C as biomarkers of acute kidney injury in critically ill neonates / / Pediatr Nephrol. - 2012. - №27(5). - P.851-860.

\section{Ахундова Н.Э. \\ Особенности гормональных изменений у женщин с гипертиреозом и с синдромом гиперандрогении репродуктивного возраста}

Азербайджанский Медицинский Университет (Азербайджан, Баку)

doi: $10.18411 /$ gdsn-25-12-2019-08

idsp: scienceconf-25-12-2019-08

\section{Аннотация}

Цель исследования - изучить особенности гормональных изменений у женщин с субклинической формой тиреотоксикоза и ГА.

Клинический материал и методы исследования: Всем больным с тиреотоксикозом и синдромом гиперандрогении (ГА) были определены показатели фолликулостимулирующего (ФСГ), лютеинизирующего (ЛГ), тиреостимулирующего (ТСГ) гормонов, пролактина (Прл), эстрадиола $\left(Э_{2}\right)$, эстрона $\left(Э_{1}\right)$, общего тестостерона $\left(\mathrm{T}_{\text {общ }}\right)$, дегидроэпиандростерон-сульфата (ДГЭА-С), 17-гидроксипрогестерона (17-ОП), свободного трийодтиронина $\left(\mathrm{T}_{3 с в о б}\right)$, свободного тироксина $\left(\mathrm{T}_{4}\right.$ своб), глобулина связывающего полового гормона (ГСПГ), андростендиона, антимюллерового гормона.

Результаты исследования: Было установлено, что у больных с гипертиреозом и

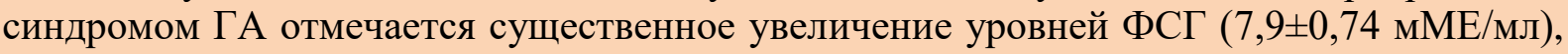

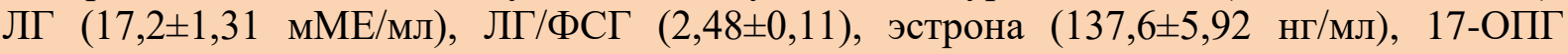

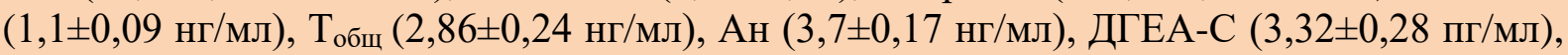
$\mathrm{T}_{\text {зсвоб }}\left(4,46 \pm 0,14\right.$ пг/мл), $\mathrm{T}_{4 \text { своб }}(2,53 \pm 0,13$ нг/мл), а также снижение показателей ТСГ $\left(0,39 \pm 0,003\right.$ мМЕ/мл), Э Э $_{2}(49,86 \pm 4$ пг/мл), ГСПГ $(49,65 \pm 1,2$ нмоль/л) $(\mathrm{P}<0,05)$. Комплексная патогенетическая терапия включающая на первом этапе лечение гипертиреоза тирозолом 5-10 мг/сут, в течение 3 месяца с подбором индивидуальной дозы, с последующим лечением синдрома гиперандрогении с препаратами комбинированной оральной контрацепции, что позволило снизить показатели ЛГ $(9,17 \pm 0,84$ мМЕ/мл), ЛГ/ФСГ $(1,36 \pm 0,07), \quad$ эстрона $(114,0 \pm 3,74 \quad$ нг/мл), $17-О П Г$ $\left(0,78 \pm 0,03\right.$ нг/мл), $\mathrm{T}_{3 \text { своб }}\left(2,87 \pm 0,07\right.$ пг/мл), $\mathrm{T}_{4 \text { своб }}(1,48 \pm 0,05$ нг/мл), Ан $(2,64 \pm 0,008$ нг/мл), ДГЕА-С $(2,15 \pm 0,14$ пг/мл), Т общ $(1,32 \pm 0,1$ нг/мл) и увеличить показатели Э $(69,46 \pm 2,58$ пг/мл), ГСПГ (59,59 2,8 нмоль/л) и ТСГ (1,79 $\pm 0,16$ мМЕ/мл).

Комплексная патогенетическая терапия восстанавливает менструальную и генеративную функции женщин с гипертиреозом и синдромом гиперандрогении.

Ключевые слова: тиреотоксикоз, синдром гиперандрогении, репродуктивный период 


\begin{abstract}
The purpose of the study was to study the features of hormonal changes in women with a subclinical form of thyrotoxicosis of hyperandrogenism.

Clinical material and research methods: 63 women with thyroid diseases with clinical manifestations of hyperandrogenism were examined. Of these, in 17 (27.0\%) clinical and diagnostic manifestations of hyperthyroidism and hyperandrogenism were determined. For all patients with thyrotoxicosis and hyperandrogenism syndrome (HA) there were determined the levels of follicle-stimulating (FSH), luteinizing (LH), thyroid-stimulating (TSH) hormones, prolactin $(\operatorname{Prl})$, estradiol $\left(\mathrm{E}_{2}\right)$, estrone $\left(\mathrm{E}_{1}\right)$, and total testosterone $\left(\mathrm{T}_{\text {total }}\right)$ as well as levels of dehydroepiandesterone sulphate (DHEA-C), 17-hydroxyprogesterone (17-OHP), free triiodothyronine $\left(\mathrm{T}_{3 \text { free }}\right)$, free thyroxin $\left(\mathrm{T}_{4 \text { free }}\right)$, sex hormone binding globulin $(\mathrm{SHBG})$, androstenedione, and antimullerian hormone.

Results of the study: It was found out that in patients with hyperthyroidism and HA syndrome, a significant increase in the levels of FSH $(7.9 \pm 0.74 \mathrm{mIU} / \mathrm{ml}), \mathrm{LH}(17.2 \pm 1.31$ $\mathrm{mIU} / \mathrm{ml}), \mathrm{LH} / \mathrm{FSH}(2.48 \pm 0.11)$, estrone $(137.6 \pm 5.92 \mathrm{ng} / \mathrm{ml}), 17-\mathrm{OCG}(1.1 \pm 0.09 \mathrm{ng} / \mathrm{ml}), \mathrm{T}$ $(2.86 \pm 0.24 \mathrm{ng} / \mathrm{ml})$, AMH $(3.7 \pm 0.17 \mathrm{ng} / \mathrm{ml})$, DHEA-C $(3.32 \pm 0.28 \mathrm{pg} / \mathrm{ml}), \mathrm{T}_{3}$ free $(4.46 \pm 0.14$ $\mathrm{pg} / \mathrm{ml}), \mathrm{T}_{4}$ free $(2,53 \pm 0.13 \mathrm{ng} / \mathrm{ml})$, as well as a decrease in TSH $(20.1 \pm 1.4 \mathrm{mIU} / \mathrm{ml}), \mathrm{E}_{2}$ $(49.86 \pm 4 \mathrm{pg} / \mathrm{ml})$, SHBG $(49.65 \pm 1.2 \mathrm{nmol} / \mathrm{L})(\mathrm{P}<0.05)$ levels. Complex pathogenetic therapy, which includes treatment of hyperthyroidism with tyrosol $5-10 \mathrm{mg} /$ day at the first stage, for 3 months with the selection of an individual dose, followed by treatment of hyperandrogenism syndrome with combined oral contraceptive drugs, which allowed to reduce the LH parameters $(9.17 \pm 0.84 \mathrm{mIU} / \mathrm{ml}), \mathrm{LH} / \mathrm{FSH}(1.36 \pm 0.07)$, estrone $(114.0 \pm 3.74 \mathrm{ng} / \mathrm{ml}), 17-\mathrm{OHP}$ $(0.78 \pm 0.03 \mathrm{ng} / \mathrm{ml}), \mathrm{T}_{3 \text { free }}(2.87 \pm 0.07 \mathrm{pg} / \mathrm{ml}), \mathrm{T}_{4 \text { free }}(1.48 \pm 0.05 \mathrm{ng} / \mathrm{ml})$, An $(2.64 \pm 0.008 \mathrm{ng} / \mathrm{ml})$, DHEA-S $(2.15 \pm 0.14 \mathrm{pg} / \mathrm{ml}), \mathrm{T}_{\text {total }}(1.32 \pm 0.1 \mathrm{ng} / \mathrm{ml})$ and increase the values of $\mathrm{E}_{2}(69.46 \pm 2.58$ $\mathrm{pg} / \mathrm{ml})$, SHBG $(59.59 \pm 2.8 \mathrm{nmol} / \mathrm{L})$ and TSH $(1,79 \pm 0,16 \mathrm{mIU} / \mathrm{ml})$ was conducted.

Combined pathogenetic therapy reduces the clinical manifestations of hyperthyroidism and HA syndrome, and restores the menstrual and generative functions of women.

Key words: thyrotoxicosis, hyperandrogenism syndrome, reproductive period
\end{abstract}

Актуальность проблемы. Гипертиреоз - это эндокринный синдром, сопровождающийся избыточным содержанием уровня тиреоидных гормонов в сыворотке крови.

Диагностика тиреотоксикоза основывается на характерных клинических проявлениях включающих симптомы и признаки тиреотоксикоза, увеличение свободного тироксина и свободного тиронина и низким соединением тиреотропного гормона (ТТГ) $(1,2,3)$.

Одним из клинических проявлений гипертиреоза является гиперандрогения (ГА). В основе ГА определяется повышение количества и/или активности андрогенов $(4,5,6)$.

По данным научных исследований в основе ГА отмечается повышение уровня дегидроэпиандростерона (ДГЕА) и дегидроэпиандростерон-сульфата (ДГЕА-С), андростендиона $(А н), \quad \Delta 4$-андростендиона, $\Delta 5$-андростендиола, тестостерона, $5 \alpha$ дигидротестостерона $(7,8,9,10)$.

Следует отметить, что в литературе практически отсутствуют сведения об особенностях изменения уровня гормонов у больных с тиреотоксикозом и синдромом ГА.

Исходя из актуальности настоящей проблемы, определена цель настоящего исследования: изучить особенности гормональных изменений $\mathrm{y}$ женщин $\mathrm{c}$ субклинической формой тиреотоксикоза и ГА.

Клинический материал и методы исследования. Исходя из цели исследования были обследованы 63 женщины с заболеваниями щитовидной железы и клиническими проявлениями ГА.

В результате обследования было выявлено, что из 63 женщин с заболеванием щитовидной железы у 17 (27\%) были определены клинико-диагностические проявления гипертиреоза и гиперандрогении. 
В результате проводимого обследования было установлено, что средний возраст больных с гипертиреозом и синдромом ГА составил 28,24 1 ,57 (21-42) лет. Исследование особенностей менструальной функции позволило выявить, что менархе у этих больных

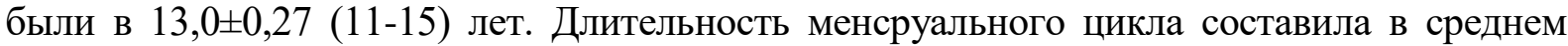

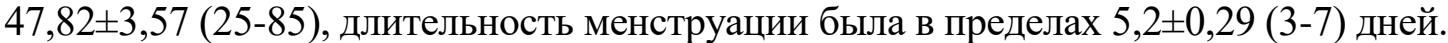

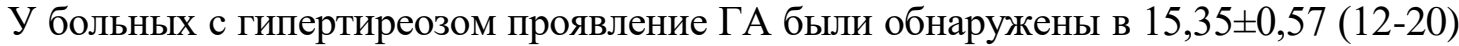
лет. При обследовании было установлено, что средний вес у больных с тиреотоксикозом и

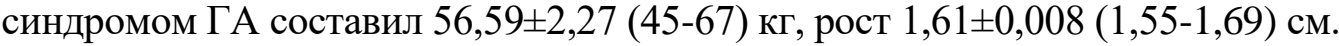

Исследование больных с гипертиреозом позволило установить, что гирсутное число у больных с гипертиреозом по шкале Ферримана-Голвея составило 18,2 $\pm 0,36$ (16$21)$ балов, гормональное число $15,1 \pm 0,37$ (13-18) балов, индифферентное число было в

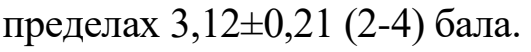

Всем больным с тиреотоксикозом и синдромом ГА были проведены гормональные исследования.

Были определены в сыворотке крови уровни фолликулостимулирующего (ФСГ), лютеинизирующего (ЛГ), тиреостимулирующего (ТСГ) гормонов, а также определены уровни пролактина (Прл), эстрадиола $\left(\mathrm{E}_{2}\right)$, эстрона $\left(\mathrm{E}_{1}\right)$, общего тестостерона $\left(\mathrm{T}_{\text {общ }}\right)$, дегидроэпиандростерона-сульфат (ДГЕА-С), кортизола (К), 17-гидроксипрогестерона (17-ОПГ), свободного трийодтиронина ( $\left.\mathrm{T}_{3 с в о б}\right)$, свободного тироксина $\left(\mathrm{T}_{4 с в о б}\right)$, глобулина связывающего полового гормона (ГСПГ), антимюллерового гормона (АМГ), андростендиона (Ан).

Полученные результаты подвергались статистической обработке. При этом применялась компьютерная программа "Statgraph" предназначенная для статистической обработки данных параметрическим и непараметрическим способом.

Результаты исследования. В результате проведенного исследования были определены уровни гормонов гипоталамо-гипофизарно-надпочечниково-яичниковой и гипоталамо-гипофизарно-тиреоидной систем. Полученные результаты представлены в таблице 1.

Таблица 1

Показатели гормонов у женщин с гипертиреозом и ГА находящихся в репродуктивном периоде $(\mathrm{M} \pm \mathrm{Se})$

\begin{tabular}{|c|c|c|c|}
\hline \multirow[b]{2}{*}{ Гормоны } & \multicolumn{2}{|c|}{ Группы исследования } & \multirow[b]{2}{*}{$\mathrm{P}$} \\
\hline & $\begin{array}{c}\text { Женщины с гипертиреозом } \\
\text { и ГА }(\mathrm{n}=17)\end{array}$ & $\begin{array}{c}\text { Практически здоровые } \\
\text { женщины }(\mathrm{n}=20) \\
\end{array}$ & \\
\hline ФСГ, мМЕ/мЛ & $7,9 \pm 0,74(4,9-17,7)$ & $5,9 \pm 0,13(3,7-7,8)$ & $<0,05$ \\
\hline ЛГ, мМЕ/мЛ & $17,2 \pm 1,31(10,4-30)$ & $8,21 \pm 0,39(2,6-11,5)$ & $<0,05$ \\
\hline ЛГ/ФСГ & $2,48 \pm 0,11(1,9-3,34)$ & $1,13 \pm 0,06(0,9-1,6)$ & $<0,05$ \\
\hline Прл, нг/мл & $20,1 \pm 1,4(6,71-27)$ & $16,36 \pm 1,15(3,8-25,2)$ & $>0,05$ \\
\hline ТСГ, мМЕ/мЛ & $0,39 \pm 0,003(0,1-0,62)$ & $2,12 \pm 0,11(1,2-3,23)$ & $<0,05$ \\
\hline$Э_{2}$, пг/мЛ & $49,86 \pm 4(25-74)$ & $89,23 \pm 0,35(40128)$ & $<0,05$ \\
\hline$Э_{1}$, нг/мЛ & $137,6 \pm 5,92(74-165)$ & $56,51 \pm 5,38(48,3-80,5)$ & $<0,05$ \\
\hline 17-ОП, нг/мЛ & $1,1 \pm 0,09(0,2-1,9)$ & $0,14 \pm 0,001(0,01-0,5)$ & $<0,05$ \\
\hline $\mathrm{T}_{\text {общ, }}$, нг/мЛ & $2,86 \pm 0,24(1,96-4,8)$ & $0,21 \pm 0,03(0,08-0,46)$ & $<0,05$ \\
\hline К, нг/мл $8^{00}-10^{00}$ & $138,47 \pm 6,4(80-184)$ & $115 \pm 0,16(70-150)$ & $<0,05$ \\
\hline Ан, нг/мл & $3,7 \pm 0,17(2,1-4,6)$ & $2,11 \pm 0,09(0,9-2,0)$ & $<0,05$ \\
\hline ДГЭА-С, пг/мл & $3,32 \pm 0,28(1,9-5)$ & $1,28 \pm 0,18(0,6-2,1)$ & $<0,05$ \\
\hline АМГ, нг/мЛ & $6,12 \pm 0,92(0,8-14,4)$ & $5,88 \pm 0,07(2,1-9,1)$ & $>0,05$ \\
\hline $\mathrm{T}_{3 \text { свобод }}$, Пг/мЛ & $4,46 \pm 0,14(3,7-5,6)$ & $2,18 \pm 0,08(1,41-3,0)$ & $<0,05$ \\
\hline $\mathrm{T}_{4 \text { свободн, }}, \mathrm{HГ} / \mathrm{MЛ}$ & $2,53 \pm 0,13(1,9-4)$ & $1,0 \pm 0,08(0,7-1,71)$ & $<0,05$ \\
\hline ГСПГ, нмоль/л & $49,65 \pm 1,2(24-71) \downarrow$ & $60,8 \pm 1,44(35-90,9)$ & $<0,05$ \\
\hline
\end{tabular}

Как видно из таблицы 1, у женщин с гипертиреозом и синдромом ГА отмечается

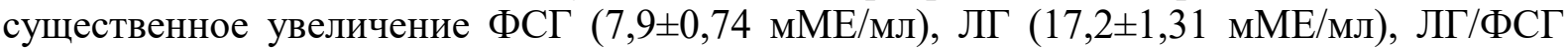
$(2,48 \pm 0,11)$, эстрона $(137,6 \pm 5,92$ нг/мл), 17-ОПГ $(1,1 \pm 0,09$ нг/мл), Т общ $(2,86 \pm 0,24$ нг/мл),

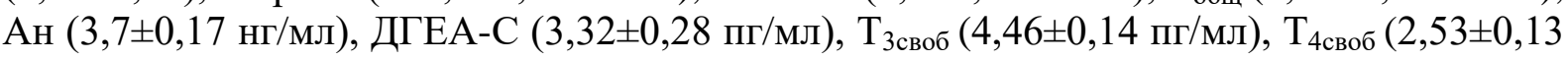
нг/мл) по сравнению с аналогичными показателями практически здоровых женщин. В 
тоже время у обследованных женщин отмечалось статистически достоверное снижение

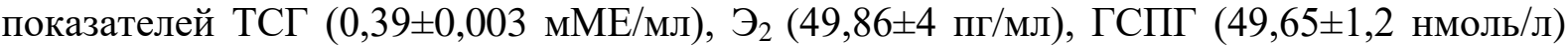
$(\mathrm{P}<0,05)$.

Все женщины находились под наблюдением эндокринолога и получали комплексное патогенетическую терапию, включающую на I этапе лечение гипертиреоза Тирозолом 5-10 мкг/сут в течение 3-х месяцев в индивидуально подобранной дозе, на II этапе после повторного исследования показателей гормонов лечение синдрома ГА препаратами комбинированной оральной контрацепции (КОК).

В результате проведенного лечения через 6 месяцев после комплексной патогенетической терапии повторно были исследованы показатели гормонов. Результаты исследования представлены в таблице 2.

Таблица 2

Показатели гормонов после комплексной патогенетической терапии больных с гипертиреозом и синдромом ГА у женщчин в репродуктивном периоде $(\mathrm{M} \pm \mathrm{Se})$

\begin{tabular}{|c|c|c|c|}
\hline \multirow{2}{*}{ Гормоны } & \multicolumn{2}{|c|}{ Женщины с гипертиреозом и ГА (n=17) } & \multirow{2}{*}{$\mathrm{P}$} \\
\hline & До лечения & После лечения & \\
\hline ФСГ, мМЕ/мЛ & $7,9 \pm 0,74(4,9-17,7)$ & $6,45 \pm 0,63(4-12)$ & $>0,05$ \\
\hline ЛГ, мМЕ/мЛ & $17,2 \pm 1,31(10,4-30)$ & $9,17 \pm 0,84(4,2-18)$ & $<0,05$ \\
\hline ЛГ/ФСГ & $2,48 \pm 0,11(1,9-3,34)$ & $1,36 \pm 0,07(0,89-2)$ & $<0,05$ \\
\hline Прл, нг/мл & $20,1 \pm 14(6,71-27)$ & $16,2 \pm 0,88(6,7-21)$ & $>0,05$ \\
\hline ТСГ, мМЕ/мЛ & $0,39 \pm 0,003(0,1-0,62)$ & $1,79 \pm 0,16(0,87-3,4)$ & $<0,05$ \\
\hline$Э_{2}$, пг/мл & $49,86 \pm 4(25-74)$ & $69,46 \pm 2,58(51-85)$ & $<0,05$ \\
\hline$Э_{1}$, нг/мЛ & $137,6 \pm 5,92(74-165)$ & $114,0 \pm 3,74(79-132)$ & $<0,05$ \\
\hline 17-ОП, нг/мл & $1,1 \pm 0,09(0,2-1,9)$ & $0,78 \pm 0,03(0,6-1,1)$ & $<0,05$ \\
\hline $\mathrm{T}_{\text {общ, }}, \mathrm{Hг} / \mathrm{MЛ}$ & $2,86 \pm 0,24(1,96-4,8)$ & $1,32 \pm 0,1(0,7-2,4)$ & $<0,05$ \\
\hline К, нг/мл $8^{00}-10^{00}$ & $138,47 \pm 6,4(80-184)$ & $139,88 \pm 5,52(110-180)$ & $>0,05$ \\
\hline Ан, нг/мл & $3,7 \pm 0,17(2,1-4,6)$ & $2,64 \pm 0,008(2,1-3,11)$ & $<0,05$ \\
\hline ДГЭА-С, пг/мл & $3,32 \pm 0,28(1,9-5)$ & $2,15 \pm 0,14(1,1-3,1)$ & $<0,05$ \\
\hline АМГ, нг/мЛ & $6,12 \pm 0,92(0,8-14,4)$ & $5,92 \pm 0,85(0,8-12)$ & $>0,05$ \\
\hline $\mathrm{T}_{3 \text { свобод }}$, ПГ/МЛ & $4,46 \pm 0,14(3,7-5,6)$ & $2,87 \pm 0,07(2,3-3,3)$ & $<0,05$ \\
\hline $\mathrm{T}_{4 \text { свободн }}$, НГ/МЛ & $2,53 \pm 0,13(1,9-4)$ & $1,48 \pm 0,05(1,1-1,9)$ & $<0,05$ \\
\hline ГСПГ, нмоль/л & $49,65 \pm 1,2(24-71)$ & $59,59 \pm 2,8(44-79)$ & $<0,05$ \\
\hline
\end{tabular}

Как видно из таблицы 2, у больных с гипертиреозом и синдромом ГА комплексная патогенетическая терапия позволила существенно снизить показатели ЛГ $(9,17 \pm 0,84$ мМЕ/мл), ЛГ/ФСГ $(1,36 \pm 0,07), \quad$ эстрона $(114,0 \pm 3,74$ нг/мл), 17-ОПГ $(0,78 \pm 0,03$ нг/мЛ $), \mathrm{T}_{\text {Зсвоб }}(2,87 \pm 0,07$ пг/мЛ $), \mathrm{T}_{4 \text { своб }}(1,48 \pm 0,05$ нг/мЛ $)$, Ан $(2,64 \pm 0,008$ нг/мЛ), ДГЕА-С $\left(2,15 \pm 0,14\right.$ пг/мл), $\mathrm{T}_{\text {общ }}\left(1,32 \pm 0,1\right.$ нг/мл) и увеличить показатели $Э_{2}$ $(69,46 \pm 2,58$ пг/мл) и ГСПГ $(59,59 \pm 2,8$ нмоль/л).

Проведенная комплексная патогенетическая терапия восстанавливает менструальную и генеративную функции женщин с гипертиреозом и синдромом ГА.

\section{$* * *$}

1. Ozizova M.E. Polikistoz yumurtalıqlar sindromu ilə hipotireozun müştərək gedişi zamanı ovarial rezervin qiymətləndirilməsi: T.ü.f.d ... dis. ... avtoref. Bakı, 2016, 22 s.

2. Вихляева Е.М. Руководство по эндокринной гинекологии. М.: 2002, с. 360-395.

3. Гусейнова Н.Ф. Системизированный подход к диагностике и лечению функционального состояния щитовидной железы в сочетании с синдромом поликистозных яичников: Автореф. дис. ...докт. филос. по мед., Баку, 2012, 22 с.

4. Дедов И.И., Мельниченко Г.А. Эндокринология: национальное руко-водство. М.: ГЭОТАР-Медиа, 2012, 1072 c.

5. Кулиева Н.Д. Исследование функционального состояния системы гипофиз-щитовидная железа у женщин с метаболическим синдромом: Автореф. дис. ... докт. филос. по мед., Баку, 2012, 18 с.

6. Ghosh S., Chaudhuri S., Jain V.K. Profiling and hormonal therapy for acne in women // Indian J. Dermatol., 2014, №59, p. 107-115. 
7. Hari A., Reddy S., Hri A., Bhatia N. Premature Ovarian Failure in Autoimmune Polyglandular Syndrome // Am. J. Med. Science., 2013, vol. 2, №3, p. 770-776.

8. Haring R., Hannemann A., John U. et al. Age-specific reference ranges for serum testosterone and androstenedione concentrations in women measured by liquid chromatography-tandem mass spectrometry // Am. J. Clin. Endocrin. Metabol., 2012, №97, p. 408-415.

9. Harper J.C. Evaluating hyperandrogenism: a challenge in acne management // Am. J. Drugs Dermatol., 2008, №7, p. 527-530.

10. Karrer-Voegeli S., Rey F., Reymond M.J. Androgen dependence of hirsutism, acne, and alopecia in women: retrospective analysis of 228 patients investigated for hyperandrogenism // Medicine (Baltimore), 2009, vol. 88, №1, p. 32-45.

\section{Алиева С.C. \\ Соответствие критериям USPHS двухслойных и монолитных циркониевых реставраций: результаты исследования в течение 3-х лет}

Азербайджанский Медицинский Университет (Азербайджан, Баку)

doi: $10.18411 / g d s n-25-12-2019-09$

idsp: scienceconf-25-12-2019-09

В последние десятилетия достигнуты значительные успехи при использовании диоксида циркония в ортопедической стоматологии. Это связано с механическими свойствами циркониевой керамики и с ее внешним видом. Установлено, что цирконий является высоко биосовместимым метастабильным материалом и обладает способностью препятствовать распространению трещин [1]. В тоже время, при протезировании диоксид циркониевыми коронками имеют место сколы покрытия и утрата ретенции [2].

Цель исследования - провести сравнительную оценку качества и эффективности двухслойных и монолитных циркониевых реставраций на основании критериев USPHS.

Материал и методы. Исследование проводилось в соответствии с принципами Хельсинкской декларации Всемирной медицинской ассоциации «Рекомендации для врачей, занимающихся биомедицинскими исследованиями с участием людей» [3].

Обследован 101 пациент, из которых 43 (42,6\%) мужчин и 58 (57,4\%) женщин.

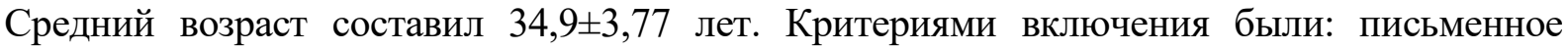
согласие участия в исследовании; резцы и клыки, нуждающиеся в ортопедическом лечении; первый или второй моляр, первый или второй премоляр, которые нуждались в монолитном восстановлении с / или без эндодонтической терапии; критериями исключения были - возраст младше 18 лет; тяжелый периодонтит; бруксизм; глубокий прикус; беременность, период кормления; тяжелые соматические заболевания. у обследованных пациентов чаще встречались зубы, значительно пораженные кариесом 41 (40,6\%), травматическое повреждение зубов отмечалось у 14 (13,9\%), отсутствие отдельных зубов - у 20 (19,8\%), эстетический вид зубов не устраивал $16(15,8 \%)$ и с дефектами установленных ранее коронок обратились 10 (9,9\%) пациентов.

Всего установлено 24 классические циркониевые коронки на передние зубы (I группа), из них на резцы установлено $11(45,8 \%)$, на боковые резцы - $8(33,3 \%)$ и клыки 5 $(20,8 \%)$ коронок. Реставрация монолитными циркониевыми коронками проведена 77 пациентам в молярной и премолярной областях. Всего установлено 98 коронок (II группа). На верхней челюсти установлено 42 (42,8\%) монолитных циркониевых коронок, из которых на премоляры зафиксировано 22 , на моляры - 20 реставраций. На нижней челюсти установлено $56(51,0 \%)$ коронок, из которых на премоляры - 26, моляры - 30 коронок. При этом у 59 (76,6\%) пациентов установлена 1 коронка, у 15 (19,5\%) - 2 коронки, у 3 (3,9\%) - 3 коронки.

Успешность фиксированных коронок была оценена через 7-10 дней, 6, 12, 18, 24 и 36 месяцев.

Для оценки одиночных коронок на исходном уровне и повторных назначений были использованы критерии Службы здравоохранения Соединенных Штатов (United 
States Public Health Service- USPHS) [4]. С помощью критериев USPHS оценены реставрации после фиксации, т.е. через 7-10 дней и 36 месяцев. Оценены, в частности, цвет, краевая посадка, краевое изменение цвета, вторичный кариес, текстура поверхности, грубые переломы. Эти показатели подразделяются на категории Альфа (Alpha), Браво (Bravo) или Чарли (Charlie): категория Альфа (A) - отсутствие проблем; категория Браво (B) - наличие осложнений в незначительной степени, Чарли (C) - осложнение серьезное или реставрация удаляется из-за осложнения. Восстановление было оценено для каждого критерия следующим образом: А - отлично; Б - хорошо; C - качество границы/ приемка, необходим ремонт /возможный; D - полный отказ, замена необходима [5].

Статистическую обработку результатов осуществляли путем использования пакета прикладных программ Microsoft Office Excel, Statistica 6,0. Описательный анализ выполнен для оценки восстановления и результата реставрации, в соответствии с измененными критериями USPHS. Применены t-тесты Стьюдента.

Результаты. По характеристике соответствие цвета из 24 реставраций высший балл А получили коронки в следующие сроки исследования: через 7-10 дней, 6 и 12 месяцев. Исследование спустя 18 месяцев показало, что показателю А отвечали 21 $(87,5 \%)$ коронок, а через 24 и 36 месяцев - $18(75,0 \%)$ и $17(70,8 \%)$ реставраций. На момент обследования через 18 месяцев 3 (12,5\%) коронки несколько отличались от соседнего зуба по оттенку и прозрачности, находясь при этом в диапазоне нормальных оттенков, что соответствовало показателю В. Дальнейшие исследования показали, что через 24 и 36 месяцев $6(25,0 \%)$ и $7(29,2 \%)$ реставраций соответственно соответствовали шкале В. Таким образом, на протяжении всего 3-х летнего периода отмечалась успешная реставрация в отношении соответствия цвету.

При оценке маргинальной целостности реставрации наивысший балл А получили 17 (70,8\%) реставраций. Оставшиеся 7 (29,2\%) коронок по этой же характеристике были оценены в балл В. При этом, в первые 7-10 дней после выполнения реставрации, а также в момент посещения спустя 6 и 12 месяцев все реставрации соответствовали шкале А. Через 18 месяцев высший балл (А) оценен в 95,8\% случаев (23 коронки), через 24 и 36 месяцев - в 91,7\% случаев (22 коронки) и 83,3\% случаев (20 коронок). Спустя 18 месяцев 1 реставрация $(4,2 \%)$ получила балл В, спустя 24 и 36 месяцев $2(8,3 \%)$ и $4(16,7 \%)$ реставраций были оценены в балл В.

Текстура поверхности в первые дни и через 6 месяцев после установки двухслойных циркониевых коронок была оценена в балл А у всех реставраций. Спустя год и полтора года 21 (87,5\%) реставрация получили высший балл соответственно, а у 3 коронок $(12,5 \%)$ поверхность имела зернистоподобную текстуру и была оценена в балл В соответственно. Через два года балл А был оценен у $20(83,3 \%)$ реставраций, а к концу исследовательского периода, т.е. через 3 года, высший балл А получили 19 (79,2\%) реставраций. На этих этапах исследования баллом Браво оценены 4 (16,7\%) и 5 (20,8\%) коронок соответственно через 2 и 3 года.

В течение всего трехлетнего периода исследования ни в одном случае не отмечена чувствительность зубов.

В течение 3-х летнего периода наблюдения 96 монолитных коронок из 98 не повредились, что привело к 97,9\%-ной выживаемости. При оценке качества реставраций, выявлено что 2 (2,0\%) реставрации, соответствовали категории Чарли из-за маргинального обесцвечивания, все остальные 96 реставраций соответствовали оценке Альфа или Браво. Процент реставраций с оценкой В для маргинального обесцвечивания в течение всего периода обследования встречался в 4,1\% случаев (4 коронки). Следовательно, результат успешной реставрации составил 97,9\%. Высший балл по этой характеристике отмечался в 95,9\% случаев (94 коронки) через 7-10 дней, в 93,9\% (92 коронки) случаев через 6 месяцев, в 95,9\% случаев (94 реставраций) в последующие 18, 24 и 36 месяцев соответственно. 
Bce 98 реставраций были оценены в балл А по таким характеристикам, как анатомическая форма, вторичный кариес, перелом. По критерию соответствие цвета высший балл А получили все реставрации через 7 дней, 6 и 12 месяцев. Спустя 18 месяцев балл А оценен в 95,9\% случаев (94 коронки), а через 24 и 36 месяцев - в 94,9\% случаев (93 коронки) соответственно. По этому критерию балл В оценен в 4,1\% (4 коронки) на этапе посещения через 18 месяцев, а также в 5,1\% случаев (5 коронок) спустя 2 и 3 года выполнения реставрации, соответственно. Схожая картина отмечалась и в отношении характеристики «целостность края». У всех 98 реставраций в период обследования от 7 дней до года был определен высший балл А. Через 18, 24 и 36 месяцев оценку высший балл получили 93 коронки $(94,9 \%)$, оставшиеся 5 (5,1\%) коронок получили балл В соответственно. В отношении показателя "текстура поверхности” оценка В изменилась с $2,0 \%$ при осмотре через 6 месяцев до 8,2\% (p<0,01). При осмотре через 3 года оценка В получена 7 (7,1\%) реставрациями. Износ естественных зубов-антагонистов через 18 месяцев в среднем составил $16,6 \pm 4,82$ мкм [8,2;25,8 мкм], что по сравнению с исходным (0 мкм) было статистически значимо $(\mathrm{p}<0,001)$.

Такие показатели, как целостность коронки, вторичный кариес по краю, проксимальные контакты коронки, центрические окклюзивные контакты, а также протрузивные и латеротрузивные контакты коронок на этапах посещения в течение всего трехлетнего периода не отличались от исходных.

Согласно критериям USPHS, маргинальная адаптация была оценена в балл А в $92,8 \%$ случаев (91 реставраций), т.е. отличная, в 7,1\% случаев (7 реставраций) оценена в балл В, т.е., как хорошая.

Таким образом, высший балл А в 3-х летний период наблюдения получен как в I группе, так и во II группе по следующим характеристикам: вторичный кариес и перелом. По характеристике соответствие цвета высший балл А получили в среднем 88,8\% и 97,6\% реставраций в I и во II группе соответственно. По характеристике анатомическая форма высший балл А в I группе получили в среднем 96,5\% реставраций, во II группе - 100\%. По характеристике обесцвечивание маргинальной поверхности, высший балл А получили в среднем 100\% и 95,6\% реставраций соответственно в I и во II группе (рис.).

- гр. (n=24) II гр. (n=98)

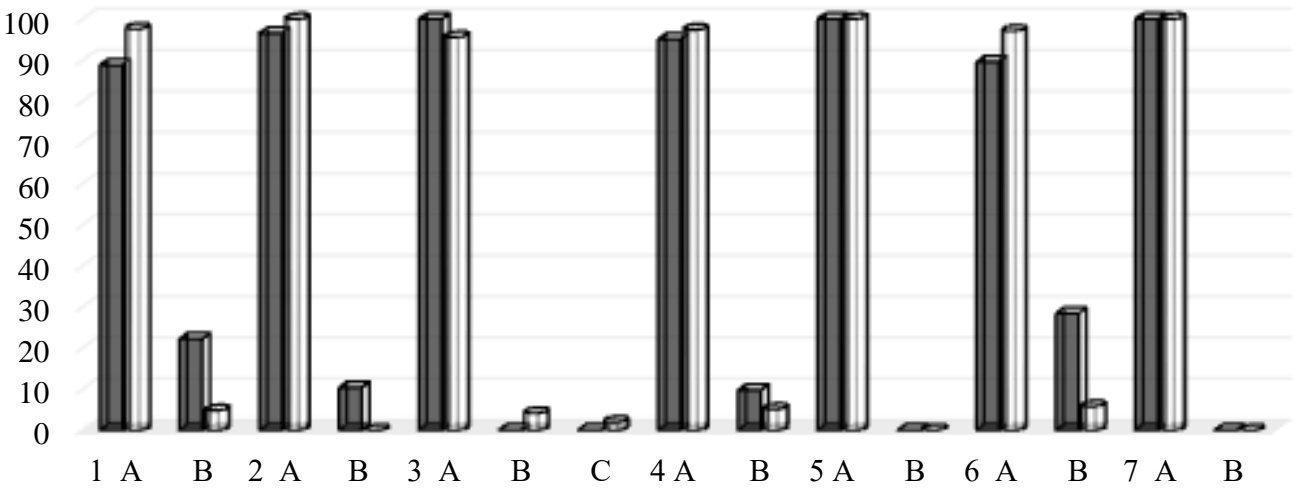

Рис. Средние результать клинической оченки реставращий в течение 3-х лет наблюдения по критериям USPHS (по оси ординат - процент реставращий, по оси абсцисс - критерии оценки)

1 - соответствие иввета; 2 - анатомическая форма; 3 -обесцвечивание краевой поверхности; 4 маргинальная целостность; 6-вторичный кариес; 6-текстура поверхности; 7 - перелом

По характеристике целостность края высший балл А получили в среднем 95,1\% реставраций в I и 97,4\% реставраций во II группе. По характеристике текстура поверхности балл А определен в среднем у 89,6\% реставраций в I группе и у 97,1\% реставраций во II группе. Как видно, относительно лучшие результаты получены при 
монолитных циркониевых реставрациях, однако статистически значимых различий между группами не отмечалось

В тоже время во II группе 2 реставрации получили балл С (Чарли).

Заключение. Получена благоприятная износостойкость монолитных коронок из диоксида циркония. Можно рекомендовать использование монолитных коронок из диоксида циркония в клинических ситуациях.

$$
* * *
$$

1. Amer R, Kurklu D, Kateeb E, Seghi RR. Three-body wear potential of “ dental yttrium-stabilized zirconia ceramic after grinding, polishing, and glazing treatments. J Prosthet Dent. 2014;112:1151-1155.

2. doi: $10.1016 /$ j.prosdent.2013.12.021

3. El-Dessouky R.A., Salama M.M., Shakal M.A, Korsel A.M. Marginal adaptation of CAD/CAM zirconiabased crown during fabrication steps. Tanta Dental Journal. 2015;12(2):81-88. https://doi.org/10.1016/j.tdj.2014.12.002

4. World Medical Association Declaration of Helsinki Ethical Principles for Medical Research Involving Human Subjects. JAMA. 2013;310(20):2191-2194. https://doi:10.1001/jama.2013.281053

5. Schmalz G, Ryge G. Reprint of Criteria for the clinical evaluation of dental restorative materials. Clinical Oral Investigations. 2005;9(4):215-232. https://doi.org/10.1007/s00784-005-0018-z

6. Bindl A, Mormann WH. Survival rate of mono-ceramic and ceramic-core CAD/CAM generated anterior crowns over 2-5 years. Eur J Oral Sci. 2004;112(2):197-204. https://doi.org/10.1111/j.16000722.2004.00119.x

Закизаде А.Э., Гурбаналиева Г.И.

Клинические и лечебные аспекты при воспалительных заболеваниях пародонта

Азербайджанский Медицинский Университет (Азербайджан, Баку)

doi: $10.18411 / g d s n-25-12-2019-10$

idsp: scienceconf-25-12-2019-10

\section{Abstract}

All subjects were divided into 3 groups. The first group (16 patients) received traditional treatment without prescribing additional drugs. The second group (15 patients), along with the traditional treatment, received course assignments in the form of applications with traditional antiseptics.

Local application of the new combined herbal preparation in the complex treatment of patients favorably affects the state of periodontal tissues in 18 patients with chronic catarrhal gingivitis and quickly relieves inflammation amid improved oral hygiene.

Key words: catarrhal gingivitis, treatment, combined herbal preparation

Проявление патологии пародонта зависит от состояния организма и отдельных его систем, поэтому важно учитывать состояние всего организма при лечении болезней органов и тканей рта. К заболеваниям, которые могут привести к патологии пародонта относят: эндокринную патологию, заболевания сердечно-сосудистой системы, желудочно-кишечного тракта и легочной системы, нервные болезни, беременность и другие $[1,2,3,4]$. В последние годы в научной и практической медицине, в том числе, и в терапевтической стоматологии время перспективным является использование биологически нейтральных лекарственных средств или фитопрепаратов, которые не оказывают негативного влияния на микробиоценоз полости рта, на его нормальную микрофлору, и, как результат, появляется возможность введения этих средств, в качестве дополнительной поддерживающей терапии, в комплексные лечебно-профилактические мероприятия для усиления терапевтического эффекта и улучшения результатов лечения в целом [5].

Цель исследований: разработать новый метод лечения хронического катарального гингивита с использованием комплексного фитопрепарата. 
Материал и методы. Исследования были выполнены на базе Стоматологической Клиники АМУ в период с 2013 по 2017 г с участием 150 пациентов с хроническим катаральным гингивитом - ХКГ. В соответствии с целью и задачами исследования все обследуемые были разделены на 3 группы. Первая группа (группа сравнения 1, 16 пациентов) получала традиционное лечение, включающее профессиональную гигиену полости рта без назначения дополнительных лекарственных средств, то есть стандартную пародонтологическую терапию. Вторая группа (группа сравнения 2 - 15 пациентов), наряду с традиционным лечением, получала курсовые назначения в виде аппликаций традиционными антисептиками. Пациентам третьей группы (основная группа - 18 пациентов) кроме вышеуказанной традиционной терапии проводили курс фитотерапии, который заключался в назначении аппликаций растительного препарата - «Immunotea». Статистический анализ полученных результатов комплексного лечения оценивали по динамике изменений субъективных ощущений пациентов и объективных индексных показателей (индекс зубного налета по Silness и Löe, индекс кровоточивости десневой борозды по Mühlemann-Cowell, папиллярно-маргинально-альвеолярный индекс PMA) до начала лечения, непосредственно после его окончания, а также в более отдаленные сроки, то есть через 1, 3, 6 и 12 месяцев после лечения.

\section{Результаты исследований.}

Индекс зубного налета по Silness и Löe в основной группе непосредственно после применения растительного препарата достоверно снизился и составил 1,06 $\pm 0,023$ балла. Аналогичная тенденция наблюдалась и на втором этапе исследований, то есть через 1 месяц после завершения лечебных процедур. Индексные данные и за это период продолжали уменьшаться и, как в предыдущий срок, самые позитивные сдвиги продолжали наблюдаться в основной группе, где с лечебной целью в качестве поддерживающей терапии использовался многокомпонентный нейтральный препарат. Здесь гигиенический индекс снизился до отметки $1,11 \pm 0,017$ балла, против $1,19 \pm 0,010$ и $1,18 \pm 0,013$ баллов в группах сравнения $(\mathrm{p}<0,001)$. Значения, меньшие исходных двух были зарегистрированы и на третьей стадии клинических исследований, приблизительно на третий месяц от начала курса базовой терапии. Через 3 месяца индекс Silness и Loe

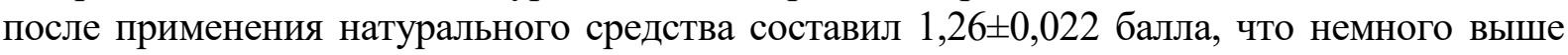
исходных значений после лечения ( $<<0,001)$. В указанные отдаленные сроки клинических исследований индекс зубного налета по Silness и Löe в группе сравнения 1 непосредственно через 6 месяцев после лечения достоверно повысился и составил $1,37 \pm 0,021$ баллов $(\mathrm{p}<0,001)$. Почти идентичное положение складывалось и в другой группе сравнения, где на предпоследнем этапе наблюдений значения гигиенического индекса выросли до отметки 1,38 $\pm 0,017$ баллов, что выше по сравнению с данными, диагностированными в двух других группах.

Индекс зубного налета по Silness и Löe в самые отдвленные сроки исследований продолжали достоверно повышаться непосредственно на 12 месяц после лечения по сравнению с показателями до лечения, как в основной группе, так и в группах сравнения 1 и 2 , и составляли в указанные сроки $1,49 \pm 0,025,1,51 \pm 0,020$ и 1,54 $\pm 0,014$ баллов $(\mathrm{p}<0,001)$, соответственно. Необходимо отметить, что начальное снижение данного индексного показателя в основной группе было связано с проведением профессиональной гигиены рта и мотивацией пациентов, а самое главное эффективным противовоспалительным и антимикробным действием растительного препарата. Сравнительный анализ результатов лечебно-профилактических мероприятий в самые отдаленные сроки клинических наблюдений, то есть через 12 месяцев, показал, что индекс кровоточивости десневой борозды в основной группе остался достоверно меньше показателей до лечения и

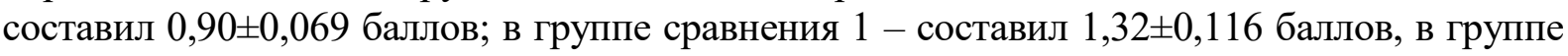
сравнения 2 составил $1,00 \pm 0,063$ балла $(\mathrm{p}<0,05 ; \mathrm{p}<0,001)$. При проведении анализа значений пародонтального индекса РМА во всех исследуемых группах после окончания лечебно-профилактических мероприятий наблюдалось снижение цифровых данных. Так, 
непосредственно после лечения в основной группе показатель индекса РМА снизился почти с $31,9 \pm 1,30 \%$ до $15,2 \pm 0,65 \%, p<0,001$, в группе сравнения 1 и группе сравнения 2 наблюдалась аналогичная динамика в снижении показателей.

Заключение: Полученные статистические данные свидетельствуют о достоверном и более выраженном снижении цифровых значений всех используемых индексов в основной группе пародонтологических больных непосредственно после проведенного лечения, а также о сохранении профилактической эффективности растительного препарата в течение всего периода наблюдений, что связано с проведением на достаточном уровне профессиональной гигиены рта, выбором оптимального лечебного средства и мотивацией самих пациентов к улучшению состояния полости рта.

$* * *$

1. Karnik R., Bhat K.M., SubrayaBhat G. Prevalence of gingival overgrowth among elderly patients under amlodipine therapy at a large Indian teaching hospital // Gerodontology. - 2012. -№ 28(1). - P.62-68.

2. Гринин В.М. Атаева Ш.З., Винниченко А.В. Колебания гормонального фона и влияние их на течение заболеваний пародонта у женщин //Стоматология. - 2012. - №1. - С.76-78.

3. Cinotti E. Arthropathy, osteolysis, keloids, relapsing conjunctivalpannus and gingival overgrowth: a variant of polyfibromatosis // Am J Med Genet A. - 2013. - Vol.161, № 6. - P.1214-1220.

4. Pisoschi C. [et al.] Evidence for the epithelialmesenchymal transition as a pathogenic mechanism of phenytoininduced gingival overgrowth // Farmacia. - 2012.-T.2. - P.168-175.

5. Кречина Е.К. Белоруков В.В. Применение фитопрепарата Artemisia absinthium L. в комплексном лечении воспалительных заболеваний пародонта // Стоматология. - 2012. - Т.91, №4. - С.22-24.

\section{Ибрагимов Ф.И. ${ }^{1,2}$ \\ Актуальные аспекты стратегии и тактики хирургического лечения тяжелых сочетанных травм}

${ }^{1}$ Институт усовершенствования врачей им. А.Алиева ${ }^{2}$ Городская клиническая больница № 3

doi: $10.18411 / \mathrm{gdsn}-25-12-2019-11$

(Азербайджан, Баку)

idsp: scienceconf-25-12-2019-11

В последнее время в связи с увеличением числа многоэтажных построек и скоростного транспорта увеличилось и число тяжелых сочетанных травм (ТСТ). Проблема ранней диагностики и лечения при ТСТ остается очень актуальной. Характерной особенностью современного травматизма является мультифокальность повреждений, при котором одновременно возникает травмирование нескольких (двух и более из 6) анатомических областей. Патогенетически обоснованное лечение и выбор рациональной хирургической тактики при ТСТ имеет первостепенное значение для снижения летальности и инвалидности. [1] Несмотря на очевидные достижения современной медицины, целый ряд ключевых аспектов проблемы, касающихся объективизации оценки тяжести травмы и состояния пострадавших, организации единой системы специализированной и квалифицированной помощи, стратегии и тактики лечения, а также социально-трудовой реабилитации пострадавших. [2]

Одной из актуальных и до конца нерешенных проблем хирургии ТСТ является лечение тяжелых повреждений опорно-двигательного аппарата, сопровождающихся полисегментарными переломами (ПСП) конечностей. Несмотря на увеличение в общей структуре сочетанных травм (СТ) удельного веса полисегментарных переломов (ПСП) нижних конечностей, до настоящего времени не разработана четкая и универсальная система тяжести состояния и организации лечебной помощи пострадавшим данной категории.[3]

Эволюция концепции лечения СТ, сопровождающихся ПСП нижних конечностей, применявшейся за последний более чем 30 лет, свидетельствует о коренной трансформации стратегии одноэтапной тотальной помощи [тактика одномоментной 
коррекции всех видов повреждений - early total care (ETC)] в многоэтапное хирургическое лечение. Современные успехи лечения пострадавших с тяжелыми МТ и СТ в значительной степени обусловлены широким внедрением в клиническую практику данной концепции, разработанной в 1990 г. специалистами Ганноверской школы политравмы, впоследствии получившей название "damage control" (контроль повреждений). Тактика травматолога при применении концепции "damage control” заключается в соблюдении принципа двух - (чаще) или трех (реже) этапных операций с максимальным ограничением объема первого вмешательства. При этом в первые сутки пострадавшим выполняются минимальные по объему и продолжительности операции для спасения жизни, такие как наложение диагностического фрезевого отверстия или минитрепанация черепа по поводу эпи- или субдуральных гематом, торакоцентез с дренированием плевральной полости по поводу пневмо- или гемоторакса, лапаротомия с временной остановкой кровотечения или с формированием энтеро- или колостом. Переломы крупных костей конечностей (прежде всего бедренной кости) у этих пострадавших иммобилизуются аппаратами наружной фиксации. По достижении надежной стабилизации витальных функций и других показателей системы гомеостаза вследствие интенсивной поликомпонентной терапии, через 24-36 часов выполняются восстановительные операции на внутренних органах, а через 5-7 сут и позже малоинвазивный остеосинтез длинных костей. Выполнение каких-либо одномоментных (синхронных) операций двумя или тремя бригадами хирургов на различных анатомических областях, проводимых ранее исключается. Эффективность применения концепции "damage control" испытана временем и подтверждена опытом многих исследователей. [4]

Цель - провести сравнительный анализ отдаленных результатов традиционного и современного методов лечения больных с ТСТ, сопровождающейся ПСП нижних конечностей.

Материал и методы. В основу данного исследования положен ретро- и проспективный анализ результатов лечения 1033 пострадавших с ТСТ, госпитализированных в клиническую больницу № 3 г. Баку за период с 2009 по 2015 гг. В зависимости от особенностей тактики лечения, применявшейся в разные хронологические периоды и для объективной оценки полученных результатов, больные были разделены на 2 статистически идентичные по полу, возрасту, локализации повреждений, группы. Основную группу составили 828 (80,2\%) пострадавших, получавших лечение за период с 2011 по 2015 гг. с применением современной стратегии. 205 (19,8\%) пострадавших, пролеченных в 2009-2010 г. с использованием традиционной тактики, включены в группу сравнения. Оценку степени тяжести травмы у пострадавших основной группы проводили по двум параметрам: индексу анатомической тяжести повреждения: AIS (Abbreniated İnjury Scale), ISS (Injury Severity Scale) и индексу тяжести состояния пострадавших с балльной (числовой) оценкой степени выраженности патофизиологических нарушений [шкала комы Глазго, TS, RTS, шкальные (балльные) системы APACHE II и APACHE III]. В основной группе лечебная тактика базировалась на применении запрограммированного многоэтапного хирургического лечения политравм в свете реализациии стратегии "damage control". Необходимым условием для реализации стратегии явился учет следующих факторов: 1.Исходная тяжесть травмы (первичный удар - “the first hit”. 2. Биологические конституции пострадавшего (возраст, пол, телосложение, масса тела, преморбидный фон). 3. Примерное (вероятное) число необходимых неотложных операций, выполняемых «по требованию».

Учитываются также травматичность и продолжительность операций, выполняемых по витальным показаниям. Эти операции, направленные по сути, на спасение жизни пострадавших, являясь своего рода хирургической агрессией (второй удар “second hit"), иногда еще более усугубляют тяжесть состояния пострадавших и нередко негативно влияют на исход лечения и прогноз. 
Результаты. Необходимо отметить, что тяжесть доминирующих травм других анатомических областей, способствующих затяжному течению острого периода травматической болезни (ТБ), явилась основной причиной, препятствующей своевременного выполнения планируемого остеосинтеза трубчатых костей. В результате запоздалая оперативная коррекция костных повреждений привела к инвалидизации 27,3\% пострадавших основной группы, 45\% - группы сравнения. С другой стороны, после технически правильно выполненного остеосинтеза длинных трубчатых костей у ряда пострадавших наблюдали такие осложнения, как миграция и ротация металлического штифта, перелом металлической пластины, смещение костных фрагментов и т.П., возникновение которых мы связывали с характером травмы (СЧМТ, ушиб головного мозга) и особеностями течения острого периода ТБ у больных, находящихся в режиме ИВЛ в связи с коматозным состоянием. Частота указанных осложнений, требующих необходимость выполнения повторного остеосинтеза, составила в основной группе $26,3 \%$, в группе сравнения - 38,7\%. Лечебная тактика при компенсированном течении ТБ у пострадавших основной группы принципиально не отличалась от таковой у пострадавших группы сравнения. При суб- и декомпенсированных вариантах ТБ у пострадавших группы сравнения применялась традиционная тактика хирургического лечения. При этом при наличии показаний к декомпрессивным вмешательствам у 24 из 33 пострадавших, операции были выполнены только у 3 (12,5\%), у которых впоследствии отмечен летальный исход. В основной группе из 56 пострадавших с суб- и декомпенсированным вариантами ТБ при наличии показаний к декомпрессивным вмешательствам у 21 (37,5\%) пострадавшего, операции выполнялись только 14 (25\%). При этом хорошие результаты были получены у 5 $(35,7 \%)$.

Таким образом, уровень летальности при сочетанной ЧМТ снизился с 50,9\% в группе сравнения до $35,3 \%$ - в основной группе. Динамика снижения уровня летальности в основной группе наблюдалась также при сочетанных повреждениях других анатомических областей. Так, если в группе сравнения летальность при сочетанных повреждениях грудной клетки и живота составила 41,2 и 44,7\% соответственно, то в основной группе больных этот показатель 25,6 и 27,8\% соответственно. Летальность при переломах бедренной кости и костей голени в группе сравнения составила 46,8 и 44,9\% соответственно. В основной группе эти показатели составили 31,7 и 33,7\%. Заметная тенденция к снижению уровня летальности в основной группе наблюдалась и при переломах плечевой кости (22\% против 51,9\% - в группе сравнения) и костей предплечья (20\% против 39,1\% - в группе сравнения).

В группе сравнения при наличии показаний к многоэтапному хирургическому лечению (МХЛ), хирургическая активность составила $12,5 \%$ и этим пострадавшим применялись традиционные методы хирургического лечения. При этом летальность составила $100 \%$. Сравнительный анализ хирургической активности между клиническими группами показывает, что к МХЛ в основной группе хирургическая активность была в 2 раза выше таковой в группе сравнения, т.к. частота декомпрессивных вмешательств в этой группе сравнения $12,5 \%$.

Повышение хирургической активности на 10,5\% при СЧМТ у больных основной группы способствовало снижению летальности на 15,6\%, при абдоминальной травме увеличение удельного веса этапных (программируемых) санационных релапаротомий на $19,6 \%$, способствовало снижению уровня летальности на 16,9\%. Увеличение частоты вмешательств при повреждениях костей таза привело к уменьшению смертности на 5,2\%.

\section{Выводы:}

1. При субкомпенсированном варианте течения ТБ у пострадавших с сочетанной абдоминальной травмой, оптимальным сроком выполнения лапаротомии в качестве первого этапа МХЛ, является 6-24 ч с момента травмы. При этом замена 
аппарата наружной фиксации на надежный остеосинтез должна быть выполнена не ранее чем на 11-15 сут.

2. При декомпенсированном течении ТБ у пострадавших с сочетанной абдоминальной травмой этапные (программируемые) санационные релапаротомии могут быть выполнены в течение 36 ч с момента травмы. При этом оптимальным сроком для выполнения надежного остеосинтеза является 17 сут (3-й этап МХЛ).

3. При тяжелой СТ у пострадавших с полисегментарными переломами конечностей первоочередной задачей является выполнение жизнеспасающих операций на органах грудной клетки, брюшной полости и таза. При этом остеосинтез закрытых ПСП должен выполняться в интервале 3-14 сут.

4. Остеосинтез, выполненный при ПСП, должен выдержать тяжесть массы тела больного и способствовать активному движению через 1-2 сут после операции.

$$
* * *
$$

1. Сахаров А.В. Основные характеристики и тенденции дорожно-транспортного травматизма в Краснодарском крае. Общественное здоровье и здравоохранение. 2011; 3: 51-54.

2. Карипиди Р.К., Сахаров А.В. Анализ тяжести первичной инвалидности вследствие дорожнотранспортных происшествий в Краснодарском крае // Кубанский научный медицинский вестник. 2010; 3-4 (117-118): 81-86.

3. Тулупов А.Н. Тяжелая сочетанная травма. 2015, Санкт-Петербург, 314 с.

4. Кокшарев И. В. Клинические показания и методика применения модифицированных корончатых фрез при хирургическом лечении больных с тяжелой черепно-мозговой травмой. Ученые Записки Спбгму Им. Акад. И. П. Павлова 2014; XXI (1): 30-33

5. Коржук М. С.,К. К. Козлов,С. В. Черненко,Т. Н. Юдакова,А. Р. Хасанов Основные положения подхода Damage control при политравме. Омский научный вестник:медицинские науки. 2015; 1 (138): 53-57

Касимова С.O.

Изучение привязанности в контексте интерперсональной психотерапии депрессии Азербайджанский Медицинский Университет (Азербайджан, Баку)

doi: $10.18411 / g d s n-25-12-2019-12$

idsp: scienceconf-25-12-2019-12

\section{Abstract}

112 patients with depression and 109 controls have been assessed with the Measure of Attachment Qualities (MAQ). Depression symptoms were assessed with Hamilton Depression Rating Scale (HDRS) and communication patterns with Interpersonal Style Questionnaire (ISQ).The odds of insecure attachment in depression group were five times greater than in heathy controls. Also it was revealed positive correlation between insecure attachment and such symptoms of depression as helplessness, anxiety and low self-esteem. The study confirmed an important role of attachment type in depression which should be considered in the course of IPT.

Keywords: depression, distancing, sociability, communication style.

Психотерапия завоевывают все большую популярность в качестве оптимального метода лечения депрессивных расстройств. При этом психотерапия является едва ли не единственным видом помощи, способствующим выздоровлению при рецидивирующих, хронических или резистентных к фармакотерапии типах депрессии. Одним из двух видов психотерапии, включенных в современные клинические рекомендации по лечению депрессии, является интерперсональная психотерапия. Популярности ИПТ способствует ее краткосрочность, структурированность, а так же эффективность, доказанная в многочисленных научных исследованиях [1].

Одним из важных аспектов ИПТ при депрессии является нарушения коммуникации депрессивных больных со своим окружением. На сегодняшний день 
считается доказанным, что факторами риска для развития депрессии являются недостаточно развитые навыки общения, выраженная зависимость и низкая степень позитивного восприятия других людей.

Привязанность относиться к био-психо-социальным системам, направленным на регулирование гомеостаза и обеспечение безопасности [2]. Привязанность лежит в основе эмоционального состояния и социальных взаимоотношений, поскольку формируясь в раннем детстве, оно определяет направление развития личности и будущие межличностные отношения [3]. Теория привязанности хорошо объясняет, как возникший в детском возрасте небезопасный межличностный стиль формирует предрасположенность к депрессии [4]. В ряде исследований была показана взаимосвязь между небезопасной привязанностью и рекуррентной депрессией, биполярным аффективным расстройством Iго и I I-го типов $[5,6]$, а так же послеродовой и атипичной депрессии $[7,8]$. Общим выводом этих исследований является то, что нарушенная привязанность сама по себе и в сочетании с другими факторами, включая наследственность, взаимоотношения, самооценку, перенесенные психотравмы определяет возникновение, течение и прогноз депрессии.

Целью исследования является изучение показателей, влияющих на формирование привязанности у больных депрессией в процессе прохождения ими интерперсональной терапии.

Материал и методы. Отбор пациентов для настоящего исследования осуществлялся из числа лиц, страдающих депрессией, обратившихся за психиатрической помощью в Центр Психического Здоровья МЗ АР (ЦПЗ) и Клиническую Психиатрическую Больницу №2 города Баку (КПБ №2). ЦПЗ является новым психиатрическим учреждением, оказывающим различные амбулаторные виды психиатрической помощи лицам детского и взрослого возраста. Для изучения типа привязанности каждому пациенту была подобрана пара из числа здоровых лиц, которые составили контрольную группу. Главным критерием включения в контрольную группу было соответствие ее участников демографическим показателям пациентов, вошедшим в основную группу. После этого была проведена оценка различных типов привязанности по шкале MAQ и проанализированы различия в основной и контрольной группе. Преимущественно безопасный тип привязанности отмечался 41 пациента с депрессий и 85 лиц из контрольной группы, соответственно небезопасный тип привязанности встречался у 59 пациентов и 26 лиц без депрессии. Сравнительный анализ по небезопасному типу привязанности в основной и контрольной группой позволил вычислить значение отношения шансов (OR), которое составило 4,7 (95\% CI = 2,25-7,45).

Результаты. Исследование показало, что шансы встретить небезопасный тип привязанности среди больных депрессией почти в 5 раз выше, чем среди лиц без признаков депрессии.

Оценка показателей по всем типам привязанности выявила статистически значимые различия в основной и контрольной группах (Рисунок). Так количество баллов по шкале безопасной привязанности у пациентов с депрессией было ниже, чем у здоровых лиц (пациенты $\mathrm{M}=8.82 ; \mathrm{SD}=2.21$, у здоровых лиц $\mathrm{M}=9.8 ; \mathrm{SD}=1.9 ; \mathrm{t}=-3.43 ; \mathrm{df}=209$; p $<0.001)$. В свою очередь значения по небезопасным типам привязанности: избегающий (пациенты $\mathrm{M}=12.1 ; \mathrm{SD}=2.74$, у здоровых лиц $\mathrm{M}=10.8 ; \mathrm{SD}=3.2 ; \mathrm{t}=2.95 ; \mathrm{df}=209 ; \mathrm{p}=0.004$ ), амбивалетно-тревожный (пациенты $\mathrm{M}=8.2 ; \mathrm{SD}=2.7$, у здоровых лиц $\mathrm{M}=5.8 ; \mathrm{SD}=2.2 ; \mathrm{t}=$ $6.82 ; \mathrm{df}=209 ; \mathrm{p}<0.001$ ) и амбивалентно-поглощающий (пациенты $\mathrm{M}=7.6 ; \mathrm{SD}=2.3, \mathrm{y}$ здоровых лиц $\mathrm{M}=5.4 ; \mathrm{SD}=2.02 ; \mathrm{t}=7.18 ; \mathrm{df}=209 ; \mathrm{p}<0.001)$ были выше в основной группе.

Результаты нашего исследования согласуются с интерперсональной теорией депрессии, поскольку люди с недостаточной безопасной привязанностью склонны фиксироваться на негативных жизненных обстоятельствах и не имеют достаточно навыков для использования ресурсов внешней поддержки, что повышает их предрасположенность к депрессии. 
Влияние небезопасного типа привязанности на уязвимость к депрессии следует рассматривать как самостоятельный фактор - лица, с небезопасным типом привязанности, находят, что испытываемые во время депрессии негативные эмоции соответствуют их общему представлению о себе. Для этих людей свойственно преувеличивать значение негативных мыслей, реакций и неудач в период депрессии. Рассмотрение взаимосвязи депрессии и типа привязанности в течение всей жизни выявило значительные различия в выраженности отдельных симптомов депрессии у лиц с различным типом привязанности. Некоторые симптомы, такие как беспомощность, тревога, соматизация, чувство вины, а так же суицидальные намерения во многом определяются недостаточно безопасным типом привязанности сформированном в преморбидном периоде.

Влияние типа привязанности на качество жизни при депрессии имеет два важных аспекта. Во-первых, небезопасная привязанность ухудшает качество межличностных отношений в течение всей жизни. Во-вторых, недостаточное межличностных отношений качество отношений, в особенности семейных и родственных, уменьшает субъективную оценку качества жизни. В этой связи можно предположить три варианта: 1) нарушенная привязанность в сочетании с депрессивными симптомами ухудшает качество жизни; 2) нарушенная привязанность приводит к депрессии, что в свою очередь снижает качество жизни; 3) депрессия и нарушенная привязанность независимо друг от друга оказывают негативное влияние на качество жизни.

Не вызывает удивления тот факт, что безопасный тип привязанности имеет отрицательно направленную корреляцию с остальными типами привязанности, однако статистически значимая корреляция обнаружена с избегающим и амбивалентопоглощающим типом.

Коррелящия между типом привязанности и депрессией

\begin{tabular}{|l|c|c|c|c|c|c|}
\hline \multicolumn{1}{|c|}{ Тип привязанности } & $\mathbf{1}$ & $\mathbf{2}$ & $\mathbf{3}$ & $\mathbf{4}$ & $\mathbf{5}$ & $\mathbf{6}$ \\
\hline Безопасный тип & 1 & & & & & \\
\hline Избегающий тип & $-0.710^{*}$ & & & & & \\
\hline Амбивалентно-тревожный тип & -0.109 & $0.244^{*}$ & & & & \\
\hline Амбивалентно-поглощающий тип & $-0.232^{*}$ & $0.374^{*}$ & $0.698^{*}$ & & & \\
\hline HDRS до начала лечения & 0.081 & 0.016 & $0.268^{*}$ & $-0.297^{*}$ & & \\
\hline Качество жизни & 0.14 & -0.151 & $-0.402^{*}$ & -0.294 & $-0.305^{*}$ & 1 \\
\hline
\end{tabular}

${ }^{*} p<0.05$

Говоря об избегающем типе привязанности, следует отметить слабую положительную корреляцию с амбивалентно-тревожным и амбивалентно-поглощающим типом. Показатели по амбивалентно-тревожному имели сильную корреляцию с показателями по амбивалентно-поглощающему типу, что может указывать на частичное совпадение этих двух типов привязанности. Следует так же отметить, что амбивалентнотревожный тип имеет сильную положительную корреляцию с выраженностью депрессии и умеренную отрицательную корреляцию с показателями качества жизни. То же самое можно сказать и в отношении амбивалентно-поглощающего типа привязанности. Важно отметить, что этот тип привязанности обнаруживает положительную корреляцию с числом предшествующих депрессивных эпизодов ( $\mathrm{r}=0.256 ; \mathrm{p}=0.011)$.

С практической точки зрения, важное значение имеет вопрос о возможности изменения типа привязанности после выхода из депрессивного состояния. В одних случаях мы могли наблюдать, как в процессе ИПТ у пациентов постепенно формировался более безопасный тип привязанности. Эти пациенты по мере выхода из депрессии формировали более конструктивные отношения с окружающими, развивали способность к сотрудничеству и чувство эмпатии. В других случаях, сформированный задолго до возникновения депрессии, устойчивый, амбивалентно тревожный, амбивалентно поглощающий или избегающий привязанностей тип препятствовал межличностному функционированию даже после полного устранения депрессивных симптомов. 
Выводы. Поскольку ИПТ построена на принципе здесь и теперь, то есть, адресована к текущим проблемам пациента, она не рассматривает возможность разрешения прошлых конфликтов, имеющих место задолго до обращения за помощью. В то же время проявление имеющегося у пациента типа привязанности, являет его стиль общения с окружающими, который остается в фокусе внимания ИПТ.

$$
* * *
$$

1. Cuijpers P, Geraedts AS, van Oppen P, Andersson G, Markowitz JC, van Straten A. Interpersonal psychotherapy for depression: a meta-analysis. Am J Psychiatry. 2011;168(6):581-92

2. Fonagy P, Steele M, Steele H, Moran GS, Higgitt AC. The capacity for understanding mental states: The reflective self in parent and child and its significance for security of attachment. Inf Ment Health J 1991; 12: $201-218$

3. O'Connor TG, Rutter M. Attachment disorder behavior following early severe deprivation: extension and longitudinal follow-up. English and Romanian Adoptees Study Team. J Am Acad Child Adolesc Psychiatry 2000; 39: 703-712

4. Widom CS, DuMont K, Czaja SJ. A prospective investigation of major depressive disorder and comorbidity in abused and neglected children grown up. Arch Gen Psychiatry 2007; 64: 49-56

5. Bifulco A, Moran PM, Ball C, Bernazzani O. Adult attachment style. I: Its relationship to clinical depression. Soc Psychiatry Psychiatr Epidemiol 2002; 37: 50-59

6. Morriss RK, van der Gucht E, Lancaster G, Bentall RP. Adult attachment in bipolar 1 disorder. Psychol Psychother 2009; 82: 267-277

7. Michalak EE, Yatham LN, Kolesar S, Lam RW. Bipolar disorder and quality of life: a patient-centered perspective. Qual Life Res 2006; 15: 25-37

8. Monk C, Leight KL, Fang Y. The relationship between women's attachment style and perinatal mood disturbance: implications for screening and treatment. Arch Womens Ment Health 2008; 11: 117-129

\section{Мамедова С.Н. \\ Характеристика степени обсемененности околоплодных вод при преждевременном разрыве околоплодных оболочек, а также слизи верхних дыхательных путей у новорожденных с РДС, родившихся от матерей с преждевременным разрывом плодных оболочек в условиях РПЦ города Баку}

Азербайджанский Медиџинский Университет (Азербайджан, Баку)

doi: $10.18411 / g d s n-25-12-2019-13$

idsp: scienceconf-25-12-2019-13

По данным ассоциации американских акушер-гинекологов (ACOG), разрыв плодных оболочек при беременности до 37 недель, составляют от 5 до 35\% и осложняют $2-4 \%$ беременностей одним плодом и 7-20\% при многоплодии $[1,2]$. До настоящего времени предложены различные теории относительно этиологии и факторов риска развития ПРПО, согласно которым наиболее частой причиной развития указанной патологии являются внутриутробное инфицирование плода, нейроэндокринная патология, различные формы экстрагенитальной патологии матери и т.п.[4]. У беременных женщин с ПРПО в сроки с 22недель до 36недель+6 дней интраамниотическая инфекция развивается в 15-30\% [3]. Основными инфекционными агентами при этом называют: стрептококки группы B, кишечные эшерихии, пептострептококки, бактероиды, уреалитическая уреаплазма, фузобактерии $[5,6]$. В то же время у рожденных недоношенных детей в связи с незрелостью легочной ткани развивается РДС, при этой патологии недоношенные дети находятся длительно на искусственной вентиляции лёгких (ИВЛ) с последующими неблагоприятными исходами . Развитие сепсиса у новорожденных при ПРПО до 34 недель беременности статистически значимо чаще у женщин с положительным результатом на такие инфекционные агенты, как Ureaplasma, Mycoplasma hominis, Chlamydia trachomatis [7]. 
Цель. Исследование характера и степени обсемененности околоплодных вод при преждевременном разрыве плодных оболочек, а также слизи верхних дыхательных путей у преждевременно рожденных детей от этих матерей.

Материал и методы. У 90 беременных, госпитализированных в отделение патологии беременности Республиканского Перинатального Центра г.Баку с диагнозом « Преждевременный разрыв околоплодных оболочек» в период с 2015-го по 2017 год при сроке беременности 22-28 полных недель гестации были проведены бактериологические исследования подтекающих ОВ, а также бактериологические исследования слизи верхних дыхательных путей у преждевременно новорожденных от этих матерей. При этом изучались характер и степень обсемененности околоплодных вод и слизи ВДП. Данное исследование проводилось в бактериальной лаборатории РПЦ Министерства Здравоохранения Азербайджанской Республики. При этом жидкий материал для посева забирался стерильной петлей с образованием в кольце петли тонкой прозрачной пленки («зеркала») с последующим равномерным распределением материала по поверхности простерилизованного заранее питательной среды в чашки Петри. Агаровую среду, в которую высевали исследуемое содержимое, предварительно стерилизовали в течении 1520 минут в автоклаве при температуре $115-120^{\circ}$ С. После чего в течении 24 часов оценивали культивацию; наличие и степень обсеменения микроорганизмами. Статистическая обработка полученных результатов проводилась в программе Microsoft Excel, оценка достоверности по критериям Стьюдента и хи-квадрат.

Результаты и их обсуждение. В результате бактериологического исследования околоплодных вод у 90 беременных, госпитализированных в ОПБ РПЦ г.Баку частота высеваемости одной инфекции составила 24,4\%. При этом, 54,5\% высевалась кишечная палочка - E.coli, в 13,6\% были определены золотистый стафиллококк (Staphylococcus aureus) и энтерококки (Enterococcus), и в единичных случаях протей (Proteus), клебсиеллы пневмонии (Klebsiyella pneumoniae), грибок возбудитель кандидоза (Candida albikans) и стрептококк группы B (Streptococcus agalactiae) (4,5\%) (Рисунок1).

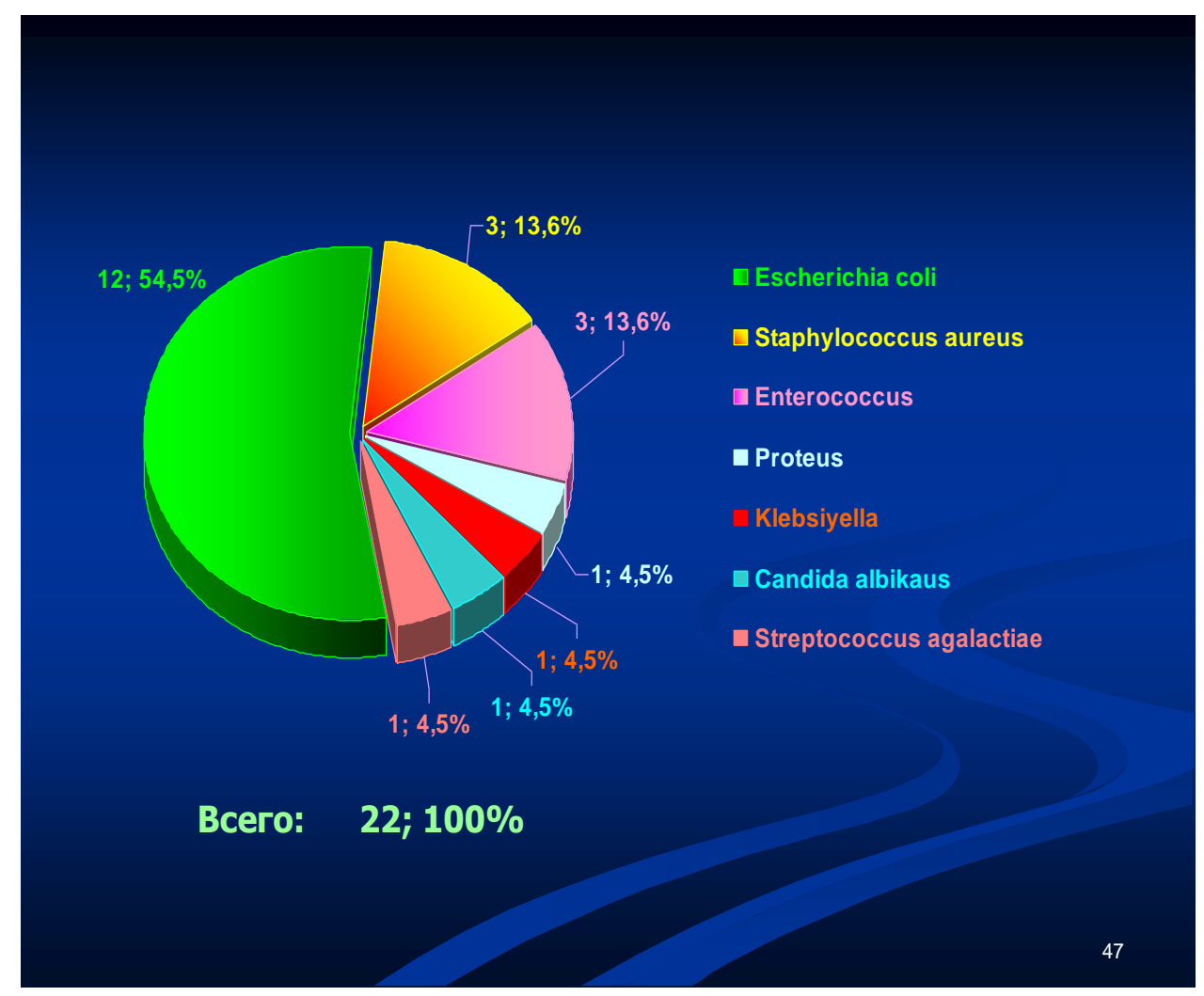

Рис.1.Характер обсемененности ОВ при преждевременном разрыве плодных оболочек при высеваемости моноинфекиии в условиях РПЦ города Баку за период 2015- 201722 (по данным проспективного исследования) 
У 63,3\% беременных с подтеканием ОВ были высеяны две инфекции. При этом в $42,1 \%$ случаев высевался золотистый стафилококк в сочетании с: с эшерихиями (17,5\%), с энтерококком (7\%) и с эпидермальным стафилококком (7\%). У $35,1 \%$ рожениц кишечная палочка сочеталась с эпидермальным стафилококком (22,8\%). У 17,5\% высевались энтерококки в сочетании: с эпидермальным стафилококком (10,5\%), в единичных случаях с сапрофитным стафилококком и грибком (3,5\%). В 5,3\% случаях эпидермальный стафилококк высевался в сочетании с грамм (-) кокками $(3,5 \%)$ и протеем $(1,8 \%)$.

Из 90 рожениц у 12,2\% (11) были высеяны 3 инфекции. При этом в 12,2\% случаев отмечалось сочетание кишечной палочки в сочетании с золотистым стафилококком и грибком. С одинаковой частотой $(18,2 \%)$ были высеяны сочетание кишечной палочки с энтерококком и грибком, сочетание золотистого стафилококка с энтерококком и эпидермальным стафилококком, и сочетание кишечной палочки с золотистым стафилококком и эпидермальным стафилококком. Следует отметить, что в исследуемых пробах отмечалась высокая частота высеваемости золотистого стафилококка $(72,7 \%)$, кишечной палочки $(63,6 \%)$ и эпидермального стафилококка $(54,5 \%)$. При проведении бактериологического исследования была определена степень обсемененности околоплодных вод независимо от характера обсеменения. Степень обсемененности околоплодных вод колебалась в пределах 105-109 КоЕ / ml.

Параллельно проводилось исследование степени обсемененности верхних дыхательных путей у новорожденных с синдромом дыхательных расстройств, родившихся от матерей с ПРПО. У 28 новорожденных $(31,1 \%)$ была высеяна моноинфекция (Рисунок 2).

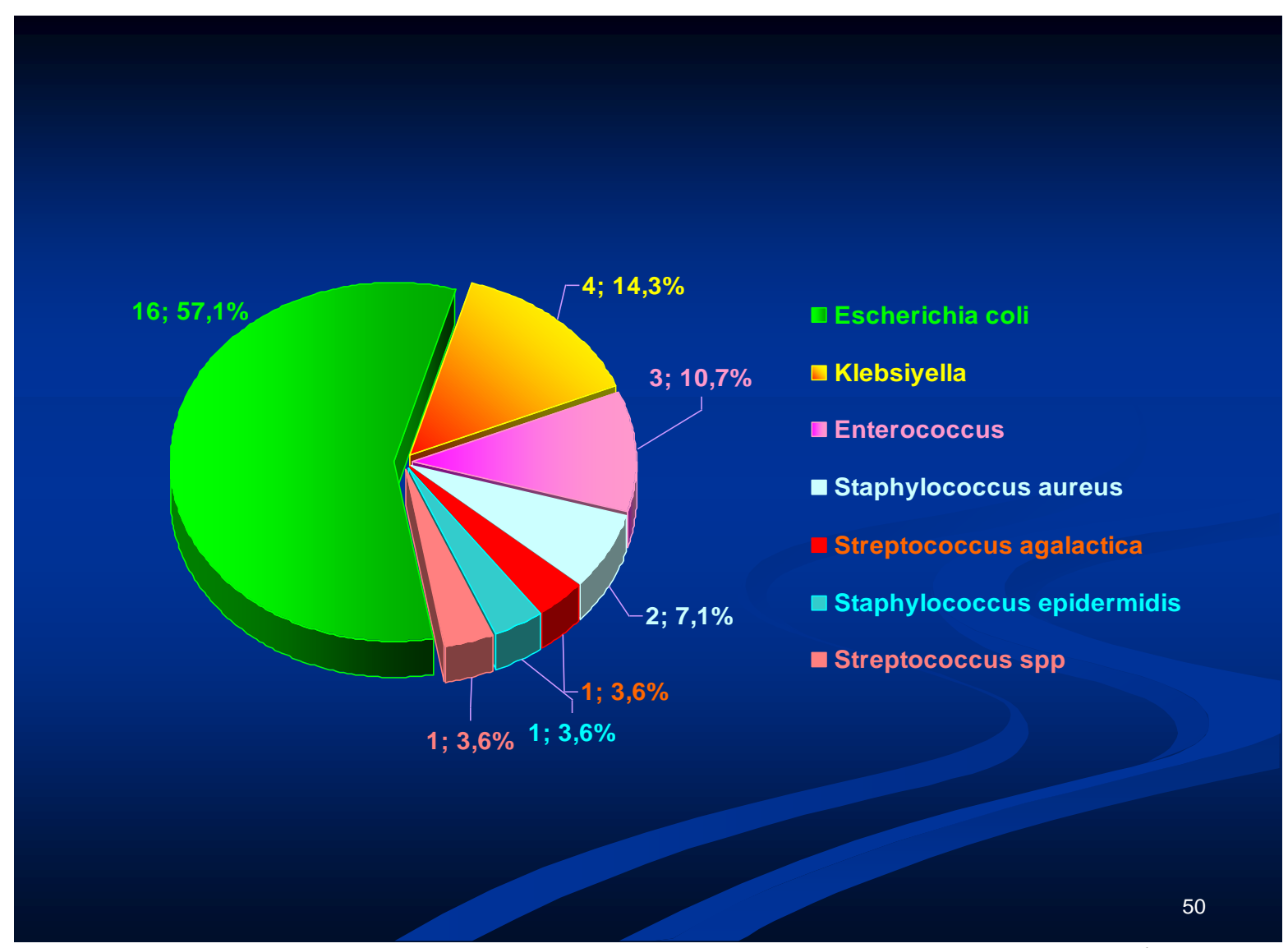

Рис.2.Характер обсемененности верхних дыхательных путей при высеваемости моноинфекции, у новорожденных от матерей с ПРПО в условиях РПЦ города Баку за период 2015- 2017г2 (по данным проспективного исследования)

При этом в 57,1\% случаев была обсемененность кишечной палочкой, в 14,3\% клебсиеллой, в 10,7\% энтерококком, в 7,1\% золотистым стафилококком. В единичных 
случаях отмечалась обсемененность стрептококком группы В, эпидермальным стафилококком и вульгарным стрептококком (Streptococcus spp). У 62 (68,9\%) новорожденных из верхних дыхательных путей было высеяно сочетание двух инфекций. При этом в 50\% случаев у новорожденных их верхних дыхательных путей высевалось сочетание кишечной палочки в 40,3\% случаев с эпидермальным стафилококком, в 6,5\% случаев отмечалось сочетание с энтерококком, и в единичных случаях с грибком $(1,6 \%)$ и протеем (1,6\%). В 24,2\% высевалось сочетание золотистого стафилококка с кишечной палочкой $(16,1 \%)$, в единичных случаях с эпидермальным стафилококком $(1,6 \%)$; клебсиеллой $(1,6 \%)$; пиодермальным стафилококком $(3,2 \%)$ и вульгарным стрептококком $(1,6 \%)$. В 16,1\% случаев эпидермальный стафилококк высевался с вульгарным стрептококком (6,5\%); с энтеробактерией $(4,8 \%)$; с кишечной палочкой $(3,2 \%)$ и в единичных случаях с клебсиеллой (1,6\%). В 9,7\% случаев отмечалось сочетание вульгарного стафилококка с эпидермальным стафилококком $(6,5 \%)$ и в единичных случаях с грибком (1,6\%) (Таблица).

Таблица

Характер обсеменения верхних дыхательных путей у новорожденных с РДС, родивиихся от матерей с ПРПО при высеваемости двух инфекций в условиях РПЦ

\begin{tabular}{|c|c|c|}
\hline \multirow{2}{*}{$\begin{array}{c}\text { Характеристика } \\
\text { обсемененностиоколоплодных вод } \\
\text { при ПРПО }\end{array}$} & \multicolumn{2}{|c|}{$\begin{array}{l}\text { Частота встречаемости сочетания двух инфекций } \\
(\mathrm{n}=57)\end{array}$} \\
\hline & Абс. & $\%$ \\
\hline $\begin{array}{l}\text { Золотистый стафилококк и другая } \\
\text { инфекция: } \\
\text { - кишечная палочка } \\
\text {-энтерококк } \\
\text {-эпидермальный стафилококк } \\
\text { - грибок } \\
\text { - грам (-) палочки } \\
\text { - клебсиела } \\
\text {-пиодермальный стафилококк } \\
\text { - стрептококк }\end{array}$ & $\begin{array}{l}10 \\
- \\
1 \\
- \\
- \\
1 \\
2 \\
1\end{array}$ & $\begin{array}{c}24.2 \\
16.1 \\
- \\
1.6 \\
- \\
- \\
1,6 \\
3,2 \\
1.6\end{array}$ \\
\hline $\begin{array}{l}\text { Кишечная палочкс и другая } \\
\text { инфекция: } \\
\text { - эпидермальный стафилококк } \\
\text {-энтерококк } \\
\text {-грибок } \\
\text {-протей }\end{array}$ & $\begin{array}{c}31 \\
25 \\
4 \\
1 \\
1\end{array}$ & $\begin{array}{c}50 \\
40.3 \\
6.5 \\
1.6 \\
1.6\end{array}$ \\
\hline $\begin{array}{l}\text { Энтерококк и другая инфекция: } \\
\text {-эпидермальный стафилококк } \\
\text { - стрептококк } \\
\text { - грибок }\end{array}$ & $\begin{array}{l}6 \\
4 \\
1 \\
1\end{array}$ & $\begin{array}{l}9.7 \\
6.5 \\
1.6 \\
1.6\end{array}$ \\
\hline $\begin{array}{l}\text { Эпидермальный стафилококк и } \\
\text { другая инфекция: } \\
\text { - грам (-) кокки } \\
\text { - протей } \\
\text { - клебсиелла } \\
\text { - стрептококк } \\
\text {-энтеробактерия } \\
\text {-кишечная палочка }\end{array}$ & $\begin{array}{l}10 \\
- \\
1 \\
1 \\
4 \\
3 \\
2\end{array}$ & $\begin{array}{c}16.1 \\
- \\
- \\
1.6 \\
6.5 \\
4.8 \\
3.2\end{array}$ \\
\hline
\end{tabular}

\section{Выводы.}

Таким образом, исследования характера и степени обсемененности околоплодных вод при преждевременном разрыве плодных оболочек позволили установить, что у 24,4\% больных высеялась моноинфекция, у 63,3\% - две инфекции, у 12.2\% - сочетание трех инфекций. При высеваемости одной инфекцией в 54,5\% случаев определена кишечная палочка, при высеваемости двух инфекций у 42,1\% отмечается сочетание золотистого 
стафилококка с другой инфекцией. При высеваемости 3 инфекций также определяется обсемененность кишечной палочкой, золотистым стафилококком и грибком. У новорожденных с различной степенью тяжести РДС, родившихся от этих матерей в отделяемом из верхних дыхательных путей в 68,9\% случаев высевались две инфекции, в $31,1 \%$ случаев - моноинфекция. Степень и характер обсемененности околоплодных вод у женщин с ПРПО в основном идентичны характеру и степени обсемененности верхних дыхательных путей новорожденных, родившихся от этих матерей.

$$
* * *
$$

1. ACOG Committee on Practice Bulletins Obstetrics. ACOG Practice Bulletin № 80. Premature rupture of membranes. Clinical management guidelines for obstetrician-gynecologist// Obstet. Gynec.,2007, Vol.109, P.1007-1019.

2. Егорова А.Т., Руппель Н.И., Моисеенко Д.А. Течение беременности и родов при спонтанном многоплодии и одноплодной беременности// Научные ведомости Белгородского государственного университета.Серия: Медицина. Фармация.2015. Т.30,№10, С.75-80

3. Макаров О.В.,Козлов П.В., Иванников Н.Ю. и соавт. Преждевременный разрыв плодных оболочек : этиология, перинатальная патология, гнойно-септические осложнения //Вопросы гинекологии, акушерства и перинатологии,2014, Т.13, №6, С.42-48.

4. Новикова В.А., Рыбалказ Е.В., Ауглева С.Р и соавт. Роль инфекции в преждевременном разрыве плодных оболочек// Российский вестник акушер-гинеколога. 2012, №6, С.43-47.

5. Орлова В.С., Калашникова И.В., НабережневЮ.И., Лысый Н.И. Современный взгляд на проблему преждевременного излития вод при недоношенной беременности // Российский вестник акушергинеколога. 2010, №5, С.17-23.

6. Селина Н.В., Карахалис Л.Ю.,Андреева М.Д. и соавт.Преждевременное излитие околоплодных вод при недоношенной беременности// Проблемы репродукции, 2012, №4, С.89-91.

7. Stepan M., Cobo T., Maly J., et al. Neonatal outcomes in subgroups of women with preterm prelabor rupture of membranes before 34 weeks // J. Matern. Fetal Neonatal Med. - 2016. - Vol. 29, № 14. - P. 2373-2377.

\section{Мамедова В.Г. \\ Влияние подключения аторвастатина к базисной терапии больных ишемической болезнью сердца и артериальной гипертензией, сочетанных с дислипидемией}

Лечебное Учреждение Министерства Юстиции Азербайджсанской Республики, Азербайджан (Азербайджан, Баку)

doi: $10.18411 / \mathrm{gdsn}-25-12-2019-14$

idsp: scienceconf-25-12-2019-14

Дислипидемии (ДЛ) часто наблюдаются как при ишемической болезни сердца (ИБС), так и при артериальной гипертензии (АГ). Сочетание ДЛ с ИБС и АГ выявляется по данным литературы примерно у 20-55\% больных [11]. В многочисленных исследованиях была подтверждена целесообразность и эффективность включения гиполипидемической терапии к базисной терапии основного заболевания $[3,6]$. Однако, исследований, посвященных оценке изменений структурно-функционального состояния миокарда при таком комбинировании лечении, недостаточно. В данном исследовании проведена оценка подключения статинов к базисной терапии больных с ИБС и АГ, сочетающихся с ДЛ на структурно-функциональное состояние и сократимость сердца.

Цель исследования - оценка эффективности, безопасности статинов при лечении больных с ИБС, АГ и их сочетанием с сопутствующей ДЛ с учетом изменений структурно-функционального состояния миокарда и показателей внутрисердечной гемодинамики.

Материал и методы. Обследовано 110 мужчин с ИБС, АГ и сочетанием ИБС и АГ с сопутствующей ДЛ в возрасте от 31 до 82 лет (средний возраст 54,9+0,9 лет). Диагноз АГ и ИБС устанавливался в соответствии с соответствующими клиническими 
рекомендациями [1,2]. Длительность заболевания ИБС от 2 до 22 лет, АГ - от 1 до 28 лет. Пациентам проведено общеклиническое, инструментальное (ЭКГ, ЭхоКГ) и лабораторное обследование (общий анализ крови, липидный профиль в плазме крови). До начала терапии исследовались исходная ЧСС, САД и ДАД, ЭКГ, показатели внутрисердечной гемодинамики [9,10] с расчетом массы миокарда (ММ) по формуле Penn Convention [7], индекса массы миокарда по отношению к площади поверхности тела (ИММ) [8] (с нормальными значениями, рассчитанными для мужчин до 115 г/м2 [5]. Определение общего холестерина $(\mathrm{OX})$ и холестерина липопротеинов высокой плотности (ЛПВП) выполнялось энзиматическим методом на биохимическом анализаторе Cobas C311 (Germany) с применением соответствующих реактивов и отражением концентрации в плазме крови в ммоль/л. Концентрацию холестерина липопротеидов низкой плотности (ЛПНП) рассчитывали по формуле W.T.Friedewald и соавт. (1972); концентрацию липопротеинов очень низкой плотности (ЛПОНП) путем деления концентрации ТГ на 5, коэффициент атерогенности (КА), выражаемый в относительных единицах, рассчитывали по формуле: ОХ-ЛПВП/ОХ [4].

Критериями включения в исследование было наличие ДЛ. Критериями исключения были пациенты с симптоматической АГ, нарушениями сердечного ритма и проводимости, сердечной недостаточностью III стадии, пороками сердца, дыхательной и почечной недостаточностью, вторичной ДЛ, заболеваниями печени в активной стадии, острыми инфекционными заболеваниями.

Длительность терапии составила 12-14 месяцев, после терапии все исследования в полном объеме проводились повторно. Всеми пациентами было подписано письменное согласие на прием препаратов. У больных с АГ и с сочетанием ИБС и АГ проводилась базисная антигипертензивная терапия, включавшая прием энапа, норипрела, экватора, эгилока, мочегонных средств (верошпирона, фуросемида, индапамида) с учетом степени АГ и мониторированием уровня в процессе терапии, у больных с ИБС назначались метаболические средства (предуктал, рибоксин, кокарбоксилаза), бета-блокаторы (эгилок), антиагрегантные и антитромботические средства (аспирин, плавикс, клопидрогрел). Обследованные больные были разделены на 2 подгруппы: 1-ая не получала гиполипидемические препараты (проводилась только базисная терапия ИБС и АГ), во 2-ой - к базисной терапии был подключен аторвастатин (аторис) (в суточной дозе 10-20 мг).

Статистическая обработка материала проводилась с использованием прикладных программ Excel 10 и Statistica 12. Нормальность распределения изучаемых признаков оценивали с помощью критериев Колгоморова-Смирнова и Шапиро-Уилка. Для расчета корреляционных зависимостей использовался метод Спирмена. При нормальном распределении для сравнения использовался t-критерий Стьюдента, при распределении, отличном от нормального, u-критерий Mann-Whitney для независимых и Wilcoxon для связанных переменных. Различия считали статистически значимыми при $p<0,05$.

Результаты и их обсуждение. Без подключения гиполипидемических препаратов получали терапию 13 (11,8\%) с ИБС, 16 (14,5\%) больных с АГ и 12 (10,9\%) больных с сочетанием ИБС и АГ, с включением аторвастатина, соответственно, 33 (30,0\%), 19 $(17,3 \%)$ и $17(15,5 \%)$ пациентов. Сравнительная динамика показателей уровня АД, ЧСС, а также ММ и ИММ в процессе терапии без включения липидоснижающих препаратов (таблица 2) продемонстрировала достоверное снижение уровней САД, ДАД и ЧСС, в то время как показатели ММ и ИММ достоверно увеличивались после терапии. В подгруппе с подключением к базисной терапии аторвастина также отмечалось снижение САД, ДАД и ЧСС, тогда как показатели ММ и ИММ заметно снижались от исходных значений после терапии, при этом в подгруппах АГ и ИБС + АГ указанное снижение было достоверным (таблица 1). 
Таблицуа 1.

Показатели САД, ДАД, ЧСС, ММ и ИММ в сравниваемых подгруппах.

\begin{tabular}{|c|c|c|c|c|c|c|}
\hline Осн. Д-3 & \multicolumn{2}{|c|}{ ИБС $(n=49)$} & \multicolumn{2}{|c|}{$\mathrm{A} \Gamma(\mathrm{n}=\mathbf{4 0})$} & \multicolumn{2}{|c|}{ ИБС + АГ $(\mathbf{n}=\mathbf{3 1})$} \\
\hline \multicolumn{7}{|c|}{ Без включения липидоснижающих препаратов } \\
\hline до/после & до $(\mathbf{n}=13)$ & $\begin{array}{c}\text { после }(\mathrm{n}= \\
13)\end{array}$ & до $(\mathbf{n}=16)$ & после (n = 16) & до $(\mathbf{n}=12)$ & после $(\mathbf{n}=12)$ \\
\hline $\begin{array}{c}\text { САД, мм } \\
\text { рт.ст. }\end{array}$ & $\begin{array}{c}135,0^{\# 1} \\
(130,0 ; 150,0 \\
)\end{array}$ & $\begin{array}{c}120,0^{\# 1} \\
(120,0 ; 135,0 \\
)\end{array}$ & $\begin{array}{c}160,0^{\# 6} \\
(160,0 ; 172,5)\end{array}$ & $\begin{array}{c}135,0^{\# 6} \\
(130,0 ; 140,0)\end{array}$ & $\begin{array}{c}167,5^{\# 11} \\
(150,0 ; 180,0 \\
)\end{array}$ & $\begin{array}{c}135,0^{\# 11} \\
(130,0 ; 145,0)\end{array}$ \\
\hline $\begin{array}{c}\text { ДАД, } \\
\text { мм.рт.ст. }\end{array}$ & $\begin{array}{c}85,0^{\# 2} \\
(75,0 ; 100,0)\end{array}$ & $\begin{array}{c}80,0^{\# 2} \\
(70,0 ; 85,0)\end{array}$ & $\begin{array}{c}100,0^{\# 7} \\
(90,0 ; 102,5)\end{array}$ & $\begin{array}{c}80,0^{\# 7} \\
(77,5 ; 85,0)\end{array}$ & $\begin{array}{c}110,0^{\# 12} \\
(95,0 ; 110,0)\end{array}$ & $\begin{array}{c}85,0^{\# 12} \\
(80,0 ; 85,0)\end{array}$ \\
\hline $\begin{array}{c}\text { ЧСС, } \\
\text { уд/мин }\end{array}$ & $\begin{array}{c}80,0^{\# 3} \\
(74,0 ; 84,0) \\
\end{array}$ & $\begin{array}{c}78,0^{\# 3} \\
(72,0 ; 78,0) \\
\end{array}$ & $\begin{array}{c}87,5^{\# 8} \\
(80,0 ; 96,0) \\
\end{array}$ & $\begin{array}{c}80,0^{\# 8} \\
(74,0 ; 83,5) \\
\end{array}$ & $\begin{array}{c}84,5^{\# 13} \\
(79,0 ; 99,0) \\
\end{array}$ & $\begin{array}{c}77,5^{\# 13} \\
(76,0 ; 82,0)\end{array}$ \\
\hline $\begin{array}{c}\text { ММ ЛЖ, } \\
\Gamma\end{array}$ & $\begin{array}{c}179,28^{\# 4} \\
(151,3 ; 293,2 \\
)\end{array}$ & $\begin{array}{c}218,5^{\# 4} \\
(185,5 ; 335,6 \\
)\end{array}$ & $\begin{array}{c}145,37^{\# 9} \\
(125,8 ; 192,3)\end{array}$ & $\begin{array}{c}179,28^{\# 9} \\
(162,4 ; 218,64)\end{array}$ & $\begin{array}{c}286,54^{\# 14} \\
(232,73 ; 312,7 \\
3)\end{array}$ & $\begin{array}{c}339,14^{\# 14} \\
(270,32 ; 378,45 \\
)\end{array}$ \\
\hline ИММ & $\begin{array}{c}96,61^{\# 5} \\
(88,86 ; 141,4 \\
)\end{array}$ & $\begin{array}{c}108,36^{\# 5} \\
(108,2 ; 168,0 \\
4)\end{array}$ & $\begin{array}{c}71,59^{\# 10} \\
(69,32 ; 103,0 \\
3)\end{array}$ & $\begin{array}{c}91,71^{\# 10} \\
(79,48 ; 117,17)\end{array}$ & $\begin{array}{c}134,33^{\# 15} \\
(113,94 ; 165,9 \\
9)\end{array}$ & $\begin{array}{c}159,32^{\# 15} \\
(135,39 ; 194,51 \\
)\end{array}$ \\
\hline \multicolumn{7}{|c|}{ + аторвастатин } \\
\hline до/после & до $(\mathbf{n}=\mathbf{3 3})$ & $\begin{array}{c}\text { после }(\mathrm{n}= \\
\mathbf{3 3})\end{array}$ & до (n= 19) & $\begin{array}{c}\text { после }(\mathrm{n}= \\
19)\end{array}$ & до (n= 17) & после $(\mathbf{n}=17)$ \\
\hline $\begin{array}{c}\text { САД, мм } \\
\text { рт.ст. }\end{array}$ & $\begin{array}{c}130,0^{* 1} \\
(120,0 ; 130 \\
0)\end{array}$ & $\begin{array}{c}120,0^{* 1} \\
(115,0 ; 120,0)\end{array}$ & $\begin{array}{c}170,0^{4^{*}} \\
(160,0 ; 180,0)\end{array}$ & $\begin{array}{c}145,0^{4^{*}} \\
(135,0 ; 150,0)\end{array}$ & $\begin{array}{c}150,0^{* 9} \\
(140,0 ; 160,0 \\
)\end{array}$ & $\begin{array}{c}130,0^{* 9} \\
(125,0 ; 140,0)\end{array}$ \\
\hline $\begin{array}{c}\text { ДАД, } \\
\text { мм.рт.ст. }\end{array}$ & $\begin{array}{c}80,0^{* 2} \\
(70,0 ; 80,0)\end{array}$ & $\begin{array}{c}78,0^{* 2} \\
(74,0 ; 86,0) \\
\end{array}$ & $\begin{array}{c}100,0^{* 5} \\
(95,0 ; 110,0)\end{array}$ & $\begin{array}{c}85,0^{* 5} \\
(80,0 ; 90,0) \\
\end{array}$ & $\begin{array}{c}90,0 * 10 \\
(85,0 ; 110,0)\end{array}$ & $\begin{array}{c}80,0 * 10 \\
(80,0 ; 80,0)\end{array}$ \\
\hline $\begin{array}{c}\text { ЧСС, } \\
\text { уд/мин }\end{array}$ & $\begin{array}{c}82,9^{* 3} \\
(75,0 ; 89,0) \\
\end{array}$ & $\begin{array}{c}78,0^{* 3} \\
(74,0 ; 86,0) \\
\end{array}$ & $\begin{array}{c}86,0^{* 6} \\
(79,0 ; 100,0) \\
\end{array}$ & $\begin{array}{c}80,0^{* 6} \\
(78,0 ; 88,0) \\
\end{array}$ & $\begin{array}{c}88,0 * 11 \\
(84,0 ; 96,0) \\
\end{array}$ & $\begin{array}{c}80,0^{* 11} \\
(76,0 ; 82,0) \\
\end{array}$ \\
\hline ММ ЛЖ, г & $\begin{array}{c}205,02 \\
(156,1 ; 246 \\
5)\end{array}$ & $\begin{array}{c}191,11 \\
(166,9 ; 262,9 \\
6) \\
\end{array}$ & $\begin{array}{c}219,33^{* 7} \\
(185,17 ; 300,6 \\
1) \\
\end{array}$ & $\begin{array}{c}213,84^{* 7} \\
(166,87 ; 247,3 \\
4) \\
\end{array}$ & $\begin{array}{c}195,51^{* 12} \\
(168,17 ; 243 \\
59)\end{array}$ & $\begin{array}{c}178,04^{* 12} \\
(152,88 ; 214,65 \\
) \\
\end{array}$ \\
\hline ИММ & $\begin{array}{c}107,19 \\
(81,3 ; 143,2 \\
)\end{array}$ & $\begin{array}{c}106,11 \\
(93,55 ; 137,0 \\
4)\end{array}$ & $\begin{array}{c}103,63^{* 8} \\
(99,36 ; 155,62 \\
)\end{array}$ & $\begin{array}{c}102,54^{* 8} \\
(83,91 ; 133,87 \\
)\end{array}$ & $\begin{array}{c}100,98^{* 13} \\
(86,99 ; 136,3 \\
)\end{array}$ & $\begin{array}{c}91,09^{* 13} \\
(76,48 ; 124,17)\end{array}$ \\
\hline
\end{tabular}

Примечания к таблице 1: ЧСС - частота сердечных сокрамений; САД систолическое артериальное давление; ДАД - диастолическое артериальное давление; \# - достоверность различий по критерию Wilcoxоn до и после лечения без включения гиполипидемических препаратов: ${ }^{\# 1}-p=0,002977 ;{ }^{\# 2}-p=0,007646 ;{ }^{\# 3}-p=0,033048$; ${ }^{\# 4}-p=0,007686 ;{ }^{\# 5}-p=0,007686 ;{ }^{\# 6}-p=0,000982 ;{ }^{\# 7}-p=0,000805 ;{ }^{\# 8}-p=$ 0,$001332 ;{ }^{\# 9}-p=0,007686 ;{ }^{\# 10}-p=0,007686 ;{ }^{\# 11}-p=0,002218 ;{ }^{\# 12}-p=0,002218 ;{ }^{\# 13}$ $p=0,007649 ;{ }^{\# 14}-p=0,007646 ;{ }^{\# 15}-p=0,007646 ;$ достоверность различий по критерию Wilcoxon до и после лечения аторвастатином: ${ }^{* 1}-p=0,000028 ;{ }^{* 2}$ $p=0,015577 ;{ }^{* 3}-p=0,003690 ;{ }^{* 4}-p=0,000132 ;{ }^{* 5}-p=0,000132 ;{ }^{* 6}-p=0,000231 ;{ }^{* 7}$ $p=0,010747{ }^{* 8}-p=0,010747 ;{ }^{* 9}-p=0,000293 ;{ }^{* 10}-p=0,000293 ;{ }^{* 11}-p=0,000549 ;{ }^{* 12}$ $p=0,023096 ;{ }^{* 13}-p=0,023096$.

Оценка наличия диастолической дисфункции (ДД) ЛЖ (релаксативного, псевдонормального и рестриктивного типа) и областей сегментарного гипокинеза (по всем отделам ЛЖ) при ЭхоКГ исследовании у обследованных пациентов в сравниваемых подгруппах продемонстрировала снижение количества участков миокарда с гипокинезом, что косвенно свидетельствовало об улучшении коронарного кровоснабжения. 
Таблииза 2.

Количество больных с диастолической дисфункиией (ДД) и сегментарным гипокинезом (СГ) ЛЖ в сравниваемых подгруппах до и после терапии.

\begin{tabular}{|c|c|c|}
\hline До/после лечения & дД Лж & СГ ЛЖ \\
\hline \multicolumn{3}{|c|}{ Без включения липидоснижающих препаратов (n = 41) } \\
\hline ИБС (до) $(\mathrm{n}=11)$ & $6(5,04 \%)$ & $5(4,17 \%)$ \\
\hline ИБС (после) $(\mathrm{n}=11)$ & $5(4,20 \%)$ & $5(4,17 \%)$ \\
\hline АГ (до) $(\mathrm{n}=14)$ & $6(5,04 \%)$ & $3(2,50 \%)$ \\
\hline АГ (после) (n=14) & $5(4,20 \%)$ & $2(1,67 \%)$ \\
\hline ИБС + АГ (до) $(\mathrm{n}=10)$ & $8(6,72 \%)$ & $5(4,17 \%)$ \\
\hline ИБС + АГ(после) $(\mathrm{n}=10)$ & $6(5,04 \%)$ & $3(2,50 \%)$ \\
\hline Всего (до) $(\mathrm{n}=35)$ & $20(16,81 \%)$ & $13(10,83 \%)$ \\
\hline Всего (после) (n=35) & $16(13,45 \%)$ & $10(8,33 \%)$ \\
\hline \multicolumn{3}{|c|}{ + аторвастатин $(\mathrm{n}=69)$} \\
\hline ИБС (до) $(\mathrm{n}=31)$ & $23(19,33 \%)$ & $15(12,50 \%)$ \\
\hline ИБС (после) (n=31) & $5(4,20 \%)$ & $4(3,33 \%)$ \\
\hline АГ (до) $(\mathrm{n}=19)$ & $12(10,08 \%)$ & $6(5,0 \%)$ \\
\hline АГ (после) (n=19) & $3(2,52 \%)$ & $0(0,0 \%)$ \\
\hline ИБС + АГ (до) $(\mathrm{n}=17)$ & $13(10,92 \%)$ & $8(6,67 \%)$ \\
\hline ИБС+АГ(после)(n=17) & $1(0,84 \%)$ & $3(2,50 \%)$ \\
\hline Всего (до) & $21(18,75 \%)^{* 1}$ & $29(24,17 \%)^{* 3}$ \\
\hline Всего (после) & $9(7,56 \%)^{* 1}$ & $7(5,83 \%)^{* 3}$ \\
\hline
\end{tabular}

Примечание к табличе 2: * - достоверность различий до и после лечения: ${ }^{*}$ - точньй двусторонний Фишера (двусторонний) 0,01442 ( $p<0,05) ;{ }^{* 2}-$ точный двусторонний Фишера (двусторонний) 0,00002 $(p<0,05)$.

Кроме того, в сравниваемых подгруппах с различным диагнозом через 12-14 месяцев терапии с включением аторвастатина отмечалось достоверное по сравнению с исходными данными снижение плазменного уровня ОХ, ЛПНП, ЛПОНП, ТГ и КА и повышение уровня ЛПВП. В подгруппах с различным диагнозом, не принимавших гиполипидемических препаратов, достоверно повышался уровень ЛПВП у больных с ИБС и АГ, достоверно снижался уровень ЛПНП, ЛПОНП, ТГ и КА только в подгруппе с $\mathrm{A} \Gamma$.

Заключение. Таким образом, полученные нами данные свидетельствуют о целесообразности включения в комбинированную терапию больных с ИБС и АГ статинов на примере аторвастатина. Подобное комбинированное лечение хорошо переносится больными при длительной терапии, оказывая наряду с выраженным гиполипидемическим действием, эффект обратного ремоделирования сердца, улучшение его диастолической функции, по-видимому, обусловленное улучшением метоболизма миокарда ЛЖ сердца у больных с ИБС и АГ с сопутствующей ДЛ.

$$
* * *
$$

1. Диагностика и лечение артериальной гипертензии. Национальные клинические рекомендации. Сборник (2-е издание.). М., изд-во «Силицея-Полиграф», 2009: 292-332.

2. Диагностика и лечение хронической ишемической болезни сердца (клинические рекомендации, разработанные по поручению Минздрава России и утвержденные Обществом специалистов по неотложной кардиологии и профильной комиссией по кардиологии), 2013, 70 с.

3. Ивашкин В.Т., Кузнецов Б.Н. Современные принципы антигипертензивной терапии. Тер. Архив, 2012, № 2, 69-75.

4. Климов А.Н. Холестерин и клетка. Актуальные проблемы патогенеза атеросклероза. Л., НИИЭМ, 1985: 26-47.

5. Шопин А.Н. Структурно-функциональное ремоделирование сердца и его прогностическое значение у лиц с множественными факторами риска и больных ишемической болезнью сердца. Дисс. докт. мед. наук., Пермь, 2011, 195 с. 
6. Blank B., LaSall J., Reeves M. et al. Single pill therapy in the treatment of concomitant hypertension and dyslipidemia (the atorvastatin/amlodipine Gemini study). J. Clin. Hypertens., 2015, Vol. 7: 264-273.

7. Devereux R.B., Reichek N. Echocardiographic determination of left ventricular mass in man: anatomic validation of the method. Circ., 1977, Vol. 55, № 4: 613-618.

8. Du Bois D., Du Bois E. A formula to estimate the approximate surface area if height and weight be known. Arch. Intern. Med., 1916, Vol. 17: 863-871.

9. Lang R.M., Bierig M., Devereux R.B. et al. Recommendations for chamber quantification. Guidelines. Eur. J. Echocardiography, 2006, Vol. 7, № 2: 79-108.

10. Stork T.V., Muller R.M., Pisce G. et al. Noninvasive measurement of left ventricular filling pressures by means of transmitral pulsed Doppler ultrasound. Am. J. Cardiol., 1989, Vol. 64, № 10: 655-660.

11. Thomas M.R., Lip G.Y.H. Novel risk markers and risk assessments for cardiovascular disease. Circ. Res., 2017, Vol. 6: 133-149. DOI: 10.1161.116. 309955.

Талыблы А.А.

Влияние синдрома гиперандрогении на особенности физического развития девочек в периоде полового созревания

Азербайджанский Медищинский Университет (Азербайджан, Баку)

doi: $10.18411 / g d s n-25-12-2019-15$

idsp: scienceconf-25-12-2019-15

\section{Abstract}

The study included 137 girls with the syndrome HECTARES in the period of puberty. All girls underwent clinical, biochemical, hormonal functional methods of research. The average age of the girls was $14.84 \pm 0.16$ years, weight $49.07 \pm 2.8 \mathrm{~kg}$, height $156 \pm 0.02 \mathrm{~cm}$. it was Found that 75 girls $(54.7 \%)$ on the Ferriman-Galway scale had mild manifestations of hirsutism, 60 (43.8\%) girls had moderate hirsutism, 2 (1.5\%) had severe hirsutism.

It was found that in the dynamics of puberty there was a statistically significant increase in shoulder width in 12-13 years, this indicator was $36.5 \pm 0.67 \mathrm{~cm}$, in $14-15$ years $38.83 \pm 0.18$ $\mathrm{cm}$, in 16-17 years $39.6 \pm 0.13 \mathrm{~cm}$. Comparison of the obtained indicators with similar physiological indicators of girls allowed to establish high indicators of shoulder width and length of the lower extremities and a decrease in the index of arm span, which reflected a predisposition to Android body type.

Key words: hyperandrogenism, puberty, Android body type, hirsutism.

На течение периода полового созревания влияет многообразие факторов, включая, питание, экологическую обстановку, пренатальные факторы, наличие физической активности, наличие хронических соматических заболеваний, наличие нейроэндокринных и иммунных нарушений, врожденных пороков развития $[1,7,8]$.

Многочисленные научные исследования относительно причин задержки полового развития в периоде полового созревания позволили выявить высокую частоту гиперандрогении (ГА) различного генеза [2,5,6].

В последние годы опубликовано большое количество работ относительно причин задержки физического и полового развития. Задержка физического развития проявляется преимущественно увеличением числа девочек с астеническим типом телосложения и низкой массой тела. Задержка физического и полового развития влияет на состояние здоровья девочек [2,3].

Одной из причин патологического течения периода полового созревания является синдром гиперандрогении (ГА), частота которого в последние годы достигает 10-20\%. При данной эндокринной патологии отмечается увеличение секреции мужских половых гормонов, либо повышение чувствительности ткани к мужским половым гормонам $[6,9]$. 
По данным различных авторов увеличение уровня андрогенов возможно вследствие воздействия стрессовых факторов, включающих психологическую и физическую напряженность, гипотермию, гипогликемию. ГА яичникового генеза сопровождается повышением секреции андростендиона и тестостерона, в основном текаклетками в стромальной ткани яичников. К андрогенам надпочечникового генеза относят дегидроэпиандростендион-сульфат (ДГЭА-С) и дегидроэпиандростендион (ДГЭА). Эти андрогены обладают слабым действием. В жировой ткани происходит конверсия андрогенов в более активные андрогены: тестостерон и дегидроэпиадростендион $[3,10]$.

«Синдром гиперандрогения» - термин, объединяющий множество заболеваний и состояний, проявляющийся наличием мужского оволосения в области лица и по всему телу, наличием на коже лица акне, выпадением волос (аллопеция), снижением тембра голоса (барифония), изменением телосложения, маскулинизацией, увеличением ширины плеч, уменьшением размеров костного таза [10].

К симптомам ГА относят:

- гипертрихоз: увеличение количества мягких и терминальных волос в области нижних конечностей, поясницы, копчика, либо по всему телу;

- гирсутизм: появление длинных жестких волос по мужскому типу на верхней губе, в области нижней челюсти, бакенбарды, околососковой области, на груди, в области нижней части живота, промежности, внутренней поверхности бедер;

- жировая себорея: повышенная сальность в области лица, лба, груди, спины, головы;

- акне: наличие камидонов, папул, фистул и цист;

- аллопеция: выпадение волос в теменной и височной области, мягкость и короткость волос на голове;

- вирилизм: наличие маскулинизации и дефиминизации гирсутизм, выпадение волос, барифония, гипертрофия клитора, задержка развития молочных желез, гипоплазия матки);

- нарушение менструальной функции: нарушение менструального цикла и менструации, включая опсоменорею, гипоменорею и аменорею $[6,7,8]$.

Следует отметить, что в литературе имеются ограниченные сведения об особенностях физического развития при синдроме ГА в периоде полового созревания.

Цель- изучение особенностей физического развития у девочек в периоде полового созревания с синдромом ГА.

Материал и методы исследования. Обследовано 137 девочек с синдромом ГА находящихся в пубертатном периоде. Обследование включало клинические, биохимические, функциональные, гормональные, рентгенологические методы

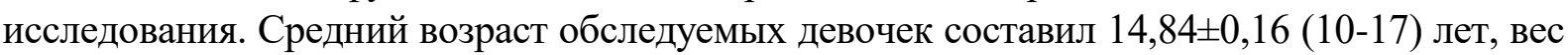

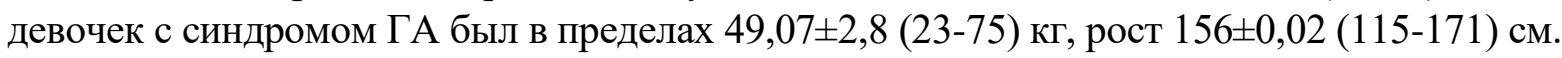

Исследование выраженности оволосения по шкале Ферримана-Голвея позволило установить, что у 75 (54,7\%) - легкое проявление гирсутизма, у 60 (43,8\%) средняя тяжесть гирсутизма и у $2(1,5 \%)$ тяжелые проявления гирсутизма.

Изучение причин синдрома ГА позволило выявить у 53,3\% наличие синдрома поликистозных яичников, у 19\% гиперпролдактинемия, у $15,3 \%$ ожирение, у 5,8\% отмечается гипотермия, у 3,6\% наличие фолликулярных кист яичников. В единичных случаях отмечалась врожденная гиперплазия коры надпочечников $1,5 \%$ и гипогонадотропный гипогонадизм 1,5\%.

Результаты исследования и их обсуждение. Показатели физического развития девочек с синдромом ГА в пубертатном периоде представлены в таблице 1 . 
Таблица 1

Показатели физического развития при синдроме гиперандрогении в пубертатном периоде $(\mathrm{M} \pm \mathrm{Se})$

\begin{tabular}{|c|c|c|c|c|}
\hline \multirow{3}{*}{ Показатели } & \multicolumn{3}{|c|}{ Группы исследования } & \multirow{3}{*}{$P$} \\
\hline & 1 & 2 & 3 & \\
\hline & 12-13 лет (n=27) & $\begin{array}{c}14-15 \text { лет } \\
(\mathrm{n}=63)\end{array}$ & 16-17 лет $(n=47)$ & \\
\hline Рост, см & $\begin{array}{r}159,9 \pm 1,47 \quad(150- \\
165)\end{array}$ & $\begin{array}{l}160,6 \pm 1,2 \\
(145-175)\end{array}$ & $\begin{array}{c}163,43 \pm 2,47 \\
175)\end{array}$ & $\begin{array}{l}\mathrm{P}_{1-2}>0,05 ; \\
\mathrm{P}_{2-3}>0,05 ; \\
\mathrm{P}_{1-3}>0,05\end{array}$ \\
\hline Вес, кг & $\begin{array}{c}48,43 \pm 2,4 \\
(33-70)\end{array}$ & $\begin{array}{l}49,84 \pm 1,25 \\
\quad(40-69)\end{array}$ & $\begin{array}{r}50,43 \pm 1,82 \\
57)\end{array}$ & $\begin{array}{l}\mathrm{P}_{1-2}>0,05 \\
\mathrm{P}_{2-3}>0,05 \\
\mathrm{P}_{1-3}>0,05\end{array}$ \\
\hline Размах рук, см & $\begin{array}{r}161,36 \pm 2,0 \quad(150- \\
172)\end{array}$ & $\begin{array}{c}161,98 \pm 1,14 \\
(147-173)\end{array}$ & $\begin{array}{r}160,7 \pm 2,19 \\
165)\end{array}$ & $\begin{array}{l}\mathrm{P}_{1-2}>0,05 \\
\mathrm{P}_{2-3}>0,05 \\
\mathrm{P}_{1-3}>0,05\end{array}$ \\
\hline Ширина плеч, см & $\begin{array}{r}36,5 \pm 0,67 \\
41)\end{array}$ & $\begin{array}{l}38,83 \pm 0,18 \\
(34-46)\end{array}$ & $\begin{array}{r}39,6 \pm 0,13 \quad(37- \\
42)\end{array}$ & $\begin{array}{l}\mathrm{P}_{1-2}<0,05 ; \\
\mathrm{P}_{2-3}>0,05 ; \\
\mathrm{P}_{1-3}<0,05\end{array}$ \\
\hline $\begin{array}{c}\text { Окружность } \\
\text { грудной клетки, см }\end{array}$ & $\begin{array}{c}70,71 \pm 1,56 \\
(61-91)\end{array}$ & $\begin{array}{l}71,47 \pm 1,0 \\
(62-82)\end{array}$ & $\begin{array}{r}75,3 \pm 1,86 \quad(73- \\
79)\end{array}$ & $\begin{array}{l}\mathrm{P}_{1-2}>0,05 \\
\mathrm{P}_{2-3}>0,05 \\
\mathrm{P}_{1-3}>0,05\end{array}$ \\
\hline Длина ног, см & $\begin{array}{r}93,5 \pm 1,91 \\
104)\end{array}$ & $\begin{array}{l}93,1 \pm 1,1 \\
(78-103)\end{array}$ & $\begin{array}{r}93,3 \pm 0,88 \\
97)\end{array}$ & $\begin{array}{l}\mathrm{P}_{1-2}>0,05 \\
\mathrm{P}_{2-3}>0,05 \\
\mathrm{P}_{1-3}>0,05\end{array}$ \\
\hline
\end{tabular}

Примечание: $P$-достоверный признак

Как видно из таблицы 1, у девочек с синдромом ГА в периоде полового созревания отмечается достоверное увеличение ширины плеч $(\mathrm{P}<0,05)$. Другие показатели физического развития в динамике пубертатного периода существенно не менялись $(\mathrm{P}>0,05)$.

Показатели физического развития у девочек с синдромом ГА были сравнены с аналогичными физиологическими параметрами представленными Наджи Л.Л. [4]. Полученные результаты представлены в таблице 2 .

Таблииа 2.

Сравнение антропометрических показателей при синдроме гиперандрогении с физиологическими показателями периода полового созревания $(M \pm S e)$

\begin{tabular}{|c|c|c|c|}
\hline \multirow{2}{*}{ Показатели } & \multicolumn{3}{|c|}{ Группы исследования } \\
\hline & 12-13 лет & 14-15 лет & 16-17 лет \\
\hline $\begin{array}{l}\text { Рост тела, см } \\
\text {-основная группа } \\
\text {-сравнительная группа }\end{array}$ & $\begin{array}{c}159,9 \pm 1,47 \\
(150-165) \\
156,42 \pm 1,45 \\
(141-170)\end{array}$ & $\begin{array}{c}160,6 \pm 1,2 \\
(145-175) \\
158,85 \pm 0,79 \\
(147-172)\end{array}$ & $\begin{array}{c}163,43 \pm 2,47 \\
(155-175) \\
161,5 \pm 1,04 \\
(150-175)\end{array}$ \\
\hline $\mathrm{P}$ & $>0,05$ & $>0,05$ & $>0,05$ \\
\hline $\begin{array}{l}\text { Масса тела, кг } \\
\text {-основная группа } \\
\text {-сравнительная группа }\end{array}$ & $\begin{array}{l}48,43 \pm 2,4(33-70) \\
44,75 \pm 2,0(25-71)\end{array}$ & $\begin{array}{c}49,84 \pm 1,25 \\
(40-69) \quad 49,44 \pm 0,73 \\
(35-61)\end{array}$ & $\begin{array}{c}50,43 \pm 1,82 \\
(45-57) \quad 52,09 \pm 1,04 \\
(41-65)\end{array}$ \\
\hline $\mathrm{P}$ & $>0,05$ & $>0,05$ & $>0,05$ \\
\hline $\begin{array}{l}\text { Размах рук, см } \\
\text {-основная группа } \\
\text {-сравнительная группа }\end{array}$ & $\begin{array}{c}161,36 \pm 2,0 \\
(150-172) \\
165,12 \pm 0,68 \\
(150-169)\end{array}$ & $\begin{array}{c}161,98 \pm 1,14 \\
(147-173) \\
168,54 \pm 0,39 \\
(155-171)\end{array}$ & $\begin{array}{c}160,7 \pm 2,19 \\
(158-165) \\
171,94 \pm 0,54 \\
(159-178)\end{array}$ \\
\hline $\mathrm{P}$ & $>0,05$ & $<0,05$ & $<0,05$ \\
\hline $\begin{array}{l}\text { Ширина плеч, см } \\
\text {-основная группа } \\
\text {-сравнительная группа }\end{array}$ & $\begin{array}{c}36,5 \pm 0,67 \quad(32-41) \\
34,52 \pm 0,79 \\
(30-38)\end{array}$ & $\begin{array}{c}38,83 \pm 0,18(34-46) \\
35,04 \pm 0,39 \\
(31-45)\end{array}$ & $\begin{array}{l}39,6 \pm 0,13(37-42) \\
37,0 \pm 0,60(32-47)\end{array}$ \\
\hline $\mathrm{P}$ & $>0,05$ & $<0,05$ & $<0,05$ \\
\hline
\end{tabular}




\begin{tabular}{|l|c|c|c|}
\hline $\begin{array}{l}\text { Окружность груд. } \\
\text { клетки, см }\end{array}$ & & & \\
-основная группа & $70,71 \pm 1,56$ & $71,47 \pm 1,0(62-82)$ & $75,3 \pm 1,86$ (73-79) \\
-сравнительная группа & $(61-91) 70,24 \pm 1,99$ & $72,80 \pm 1,03$ & $76,79 \pm 0,22$ \\
\hline Р & $(60-96)$ & $(61-99)$ & $(66-100)$ \\
\hline Длина ноги, см & $>0,05$ & $>0,05$ & $>0,05$ \\
-основная группа & $93,5 \pm 1,91$ & $93,1 \pm 1,1(78-103)$ & $93,3 \pm 0,84(94-97)$ \\
-сравнительная группа & $(79-104) 79,24 \pm 1,40$ & $81,67 \pm 0,93$ & $82,87 \pm 0,97$ \\
\hline \multicolumn{1}{|c|}{ Р } & $(73-100)$ & $(75-103)$ & $(72-105)$ \\
\hline \multicolumn{2}{|r|}{} \\
\hline
\end{tabular}

Таким образом, у девочек с синдромом ГА отмечается существенное увеличение ширины плеч в динамике полового созревания. При сравнении с физиологическими показателями отмечаются высокие показатели ширины плеч и длины ноги на фоне уменьшения показателя размаха рук. Полученные показатели позволили утверждать, что у девочек с синдромом ГА в динамике периода полового созревания преобладает андроидный тип телосложения.

$$
* * *
$$

1. Коколина В.Ф. Детская и подрастковая гинекология // М., Медпрактика, 2012, 680 с.

2. Кузнецова И.В. Девочка-подросток - как пациент. Эндокринная гинекология физиологического пубертата: оптимальный минимум коррекции // Информативный бюллетень. Редакция журнала StatusPraesens, 2014, 20 c.

3. Левенец С.А., Нечетова Т.А. Гиперпролактинемия у девушек-подростков с нарушениями менструальной функции и методы ее коррекции // Здоровье женщины, 2010, №4, с.127-128.

4. Наджи Л.А., Алиева Э.М. Особенности физического развития девочек с физиологическим течением периода полового созревания // Достижения медицинской науки Азербайджана.-2010.-№4.-səh 47-50.

5. Петеркова В.А., Семечева Т.В., Горелышев С.К. Преждевременное половое развитие. Клиника, диагностика, лечение: Пособие для врачей. М., 2013, 40 с.

6. Полтава Н.В. Эндокринные нарушения репродуктивного здоровья девочек-подростков и современные возможности их гормональной коррекции и профилактики // Автореф. дисс. ... канд.мед.наук: 14.01.01, Бишкек, 2017, 25 с.

7. Ящук А.Г. Формирование репродуктивной системы девочек-подростков в современных условиях // Репродуктивное здоровье детей и подростков, 2012, №6, с.30-44.

8. Bauman D. Diagnostic methods in pediatric and adolescent gynecology // Endocrine development, 2012, vol.22, p.40-55.

9. Fruzzetti F., Campagna A.M., Perini D., Carmina E. Ovarian volume in normal and hyperandrogenic adolescent women //Fertil Steril., 2015, №104, p.196-199.

10. Georgopoulos N.A., Kandaraki E., Panidis D.Hyperandrogenism in PCOS // Fertil.Steril., 2009, №3, p.1-6.

\section{Garashova M.A. \\ Incidence of tumors of the reproductive system in the postmenopausal period in the republic of Azerbaijan}

Azerbaijan Medical University (Azerbaijan, Baku)

doi: $10.18411 / g d s n-25-12-2019-16$

idsp: scienceconf-25-12-2019-16

\section{Abstract}

Purpose: Determination of the frequency of occurrence of genital tumors in women in the postmenopausal period in the conditions of the Azerbaijan.

Materials and methods. A retrospective study of case histories of 301 women with tumors of the reproductive organs in the postmenopausal period. The average age of patients was $61.6 \pm 0.4$ years. The duration of the postmenopausal period was $11.0 \pm 0.6$ years.

The results of the study. In the postmenopausal period there was manifestation of the uterine fibroids in $28.9 \%$ of patients. $22.9 \%$ of patients had endometrial hyperplasia, $21.6 \%$ had 
endometrial cancer, $10.6 \%$ had ovarian cancer and $8.6 \%$ of women were diagnosed cervical cancer. There was confirmed, that the incidence of benign genital tumors in postmenopausal women was $57.4 \%$, the incidence of malignant tumors was $42.6 \%$.

Key words: postmenopausal period, uterine myoma, endometrial hyperplasia, ovarian cancer, cervical cancer, serous adenocarcinoma, mucinous adenocarcinoma, atypical hyperplasia.

\section{Аннотация}

Цель: определение частоты встречаемости опухолей гениталий у женщин в постменопаузальном периоде в условиях Азербайджанской Республики.

Материал и методы. Проведено ретроспективное исследование историй болезни 301 женщины с опухолями репродуктивных органов в постменопаузальном периоде. Средний возраст больных составил $61,6 \pm 0,4$ года. Длительность постменопаузального периода была $11,0 \pm 0,6$ лет.

Результаты исследования. В постменопаузальном периоде у 28,9\% больных отмечались клинические проявления миомы матки, у 22,9\% больных гиперпластические процессы эндометрия, у 21,6\% рак эндометрия, у 10,6\% рак яичников и у $8,6 \%$ женщин был диагностирован рак шейки матки. Частота доброкачественных опухолей гениталий в постменопаузе составила $57,4 \%$, частота злокачественных опухолей составила $42,6 \%$.

Ключевые слова: постменопаузальный период, миома матки, гиперплазия эндометрия, рак яичников, рак шейки матки, серозная аденокарцинома, муцинозная аденокарцинома, атипическая гиперплазия.

Tumors of the reproductive tract include a large number and variety of benign and malignant neoplasms of the external and internal genital organs. Despite the variety of nosologies that determine the structure of cancer incidence, according to the International Agency for Research on Cancer (IARC), malignant tumors of the reproductive system account for $35 \%$ of all malignant tumors. Annually, 2.1 million women are diagnosed with breast cancer, and 1.2 million women with genital neoplasms worldwide [5].

During the process of aging on the background of extinction of the ovarian steroid synthesis there are also the reaction of cells and tissues of various target organs to hormonal and metabolic changes observed. Changes in hormones do not affect the structure of DNA and do not cause cancer, but at the same time, hormones can induce cancer $[2,3,6]$.

It was revealed that one of the causes of reproductive system tumors is the complex mechanism of neuroendocrine regulation failure. There were established following mechanisms of the genital tumors development:

- A primary decrease in the functional activity of the ovaries, including a decrease in the level of ovarian estrogens;

- Compensatory increase in the level of gonadotropins, particular FSH;

- Stimulating effect of elevated gonadotropins level on proliferating epithelium;

- The development of diffuse and then focal endometrial hyperplasia [1,5,7].

The goal of the study was to determine the frequency of genital tumors in the postmenopausal period in the conditions of the Azerbaijan Republic.

Materials and methods. Based on the purpose of the study, a retrospective study of case histories of 301 women in the postmenopausal period was conducted. All patients were examined and received appropriate treatment at the Oncology Clinic of the Azerbaijan Medical University.

The average age of women was $61.6 \pm 0.4$ and ranged from 46 to 83 years. The duration of the postmenopausal period was within $11.0 \pm 0.6(2-34)$ years.

Research results and discussion. The structure of tumors of the reproductive system in women in the postmenopausal period is presented in figure.

As can be seen from the scheme, of 301 patients, 87 (28.9\%) had clinical manifestations of uterine fibroids. In 69 patients $(22.9 \%)$, clinical and diagnostic manifestations of endometrial hyperplastic processes were determined. In 65 patients $(21.6 \%)$, endometrial cancer was 
detected. Ovarian cancer was diagnosed in $32(10.6 \%)$ patients. $26(8.6 \%)$ women were diagnosed with cervical cancer.

During the present study, the structure of endometrial hyperplastic processes was determined. It was found out that the frequency of complex endometrial hyperplasia with atypia was $12.3 \%$ (in 37 patients). The incidence of endometrial hyperplasia without atypia was within $10.6 \%$. Of these, the frequency of diffuse hyperplasia was $6.3 \%(\mathrm{n}=19)$, focal hyperplasia (polyps) $4.3 \%(n=13)$.

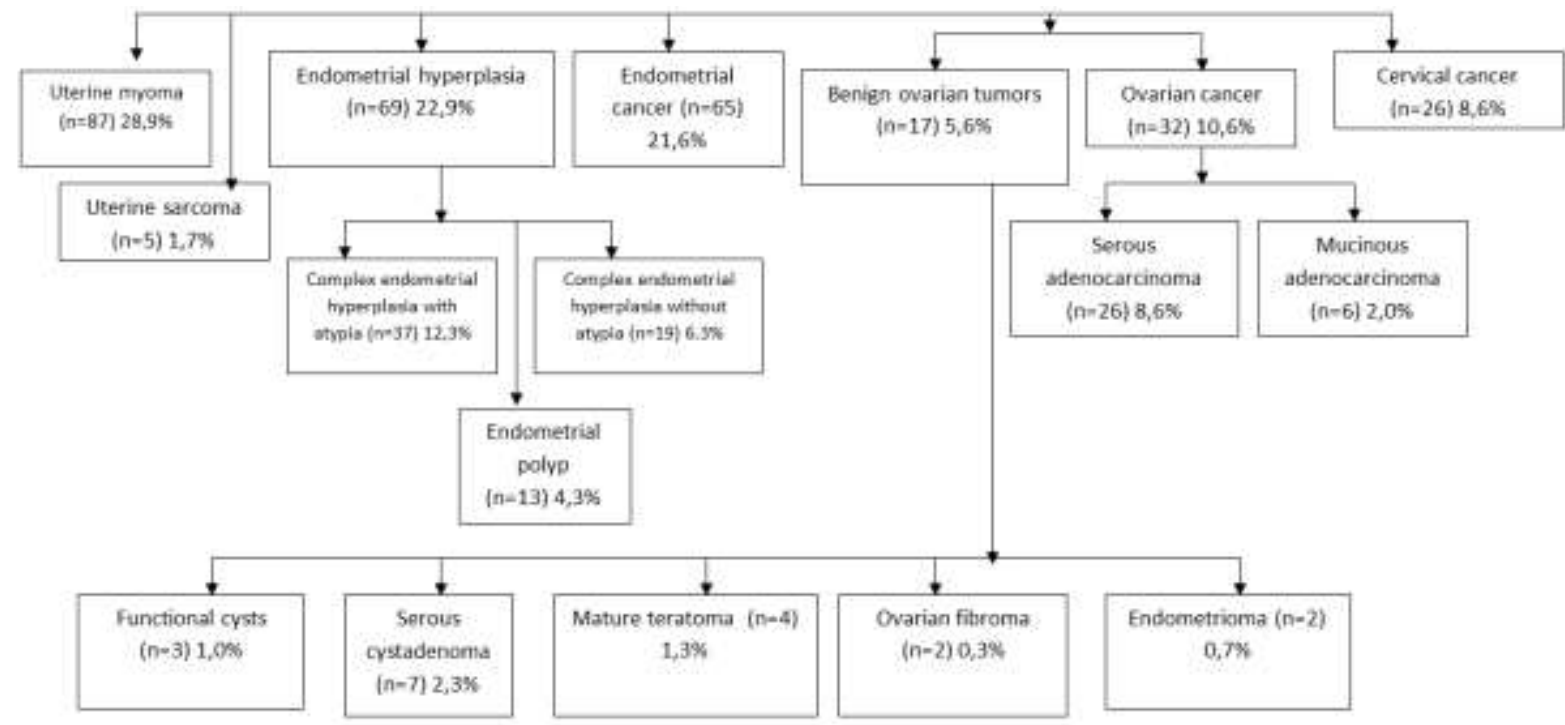

Figure. The structure and incidence of genital tumors in postmenopausal period

According to a retrospective study, in the postmenopausal period, patients with ovarian cancer $(n=32)$ in $8.6 \%$ of cases had serous adenocarcinoma, in $2 \%$ of cases mucinous adenocarcinoma.

As a result of the study, it was found out that the incidence of benign ovarian tumors was $5.6 \%$. Moreover, serous cystadenoma $(2.3 \%)$, mature teratoma $(1.3 \%)$ prevailed in the structure of benign ovarian neoplasms. It should be noted that almost the same frequency was observed in incidence of endometrioma ( $0.7 \%)$, ovarian fibroma $(0.3 \%)$, and functional ovarian cysts $(1.0 \%)$.

Thus, in the postmenopausal period, clinical and diagnostic manifestations of uterine fibroids were determined in $28.9 \%$ of patients, endometrial hyperplastic processes in $22.9 \%$, endometrial cancer in $21.6 \%$, ovarian cancer in $10.6 \%$ of patients. $8.6 \%$ of women were diagnosed with cervical cancer. At the same time, in the structure of genital tumors the proportion of benign neoplasms prevailed and was diagnosed in $57.4 \%$, malignant neoplasms in $42.6 \%$ of cases.

$* * *$

1. Ciarmela P., Islam M.S., Reis F.M. Growth factors and myometrium: biological effects in uterine fibroid and possible clinical implications // Hum.Reprod.Update, 2011, vol.17, №6, p.772-790.

2. Collaborative Group On Epidemiological Studies Of Ovarian Cancer, Beral V, Gaitskell K, Hermon C, Moser K., Reeves G., Peto R. Menopausal hormone use and ovarian cancer risk: individual participant metaanalysis of 52 epidemiological studies // Lancet., 2015, №385, p.1835-1842.

3. Dossus L., Allen N., Kaaks R., Bakken K., Lund E. Reproductive risk factors and endometrial cancer: the European Prospective Investigation into Cancer and Nutrition // Int.J.Cancer., 2010, №127, p.442-451.

4. Han K.H., Park N.H., Kim H.S., Chung H.H. Peritoneal cytology: A risk factor of recurrence for nonendometrioid endometrial cancer // Gynecol. Oncolog., 2014, №134, p.293-296.

5. IARC Biennial Report 2008-2009. Lyon: International Agency for Research on Cancer, 2009, 145 p.

6. $\quad$ Lee A.W., Ness R.B., Roman L.D., Terry K.L. Association Between Menopausal Estrogen-Only Therapy and Ovarian Carcinoma Risk // Am.J.Obstet.Gynecol., 2016, vol.127, №5, p.828-836.

7. $\quad$ Pearce C.L., Templeman C., Rossing M.A., Lee A., Near A.M. Association between endometriosis and risk of histological subtypes of ovarian cancer: a pooled analysis of case-control studies // Lancet Oncol., 2012, №13, p.385-394. 


\section{Gasimzade G.Sh. \\ Early diagnosis of traumatic brain injury \\ Azerbaijan State Institute of Advanced training of doctors named after A. Aliyev \\ (Azerbaijan, Baku)}

doi: $10.18411 / g d s n-25-12-2019-17$

idsp: scienceconf-25-12-2019-17

Traumatic brain injuries are characterized by high mortality, as well as the preservation of severe neurological or mental disorders [1,2].

Computed tomography (CT) and magnetic resonance imaging (MRI) can determine the localization of pathological processes. However, taking into account the dynamics of clinical indicators confirmed by data and other additional studies, the methods of computer and magnetic resonance imaging allow predicting the possibility of further rehabilitation $[3,4,5]$.

The aim is to analyze the results of computed tomography in patients with acute traumatic brain injury .

Material and methods of research. From 2014 to 2016, CT results of 90 persons with TBI were studied. The age of the victims ranged from 20 to 50 years, the average age was $31.56 \pm 2.09$ years. There were 80 males $(88.9 \%)$ and 10 females $(11.1 \%)$. The criteria for inclusion in the study were: victims of all age groups with TBI regardless of gender, who underwent CT; patients with a score on the Glasgow coma scale (GCS) less than 15 . The exclusion criteria were: patients with unstable hemodynamics, with penetrating injuries, with diabetes mellitus (DM) and arterial hypertension (AH), receiving anticoagulant therapy, with TBI, who suffered in childhood, pregnant women. In 54 (60.0\%) victims, the cause of TBI was an accident, in $29(32.2 \%)$ - a fall, in $6(6.7 \%)$ - a sports injury and in $1(1.1 \%)$ - a criminal injury. The patients were examined, taking into account the sex, age of the victim, the mechanism of injury, its severity. After initial care, the severity of TBI is assessed using the Glasgow coma scale (GCS). According to the Glasgow coma scale, the severity of the disorder is determined by the following scores: normal condition-15 points, mild impairment-12-14 points, average impairment-8-11 points, severe impairment $-<7$ points. The main indicator for assessing the severity of TBI on GCS was the depression of the level of wakefulness.

Native computed tomography studies were performed on the Aquilion 16 Model TSX101A computer tomograph of Toshiba (Japan). The studies were carried out on admission. Tomograms were used to assess the condition of the skull bones, soft tissues of the head, epidural, subdural, subarachnoid spaces and ventricular system. The data obtained were compared with the results of examination, traditional $\mathrm{x}$-ray examination of the skull and neurological status. Tomograms assessed the main characteristics of TBI-the integrity of the skull bones (presence or absence of fractures), the density of brain matter, the state of the ventricular system of the brain, the presence and characteristics of intracranial hemorrhages, localization of the focus of brain injury relative to the sagittal plane.

The study was carried out in accordance with the principles of the Helsinki Declaration.

Research results and their discussion. The victims were identified a variety of brain damage. The most common lesion was a concussion (36.7 per cent). The bruising rate was $33.3 \%$. A fairly high percentage were fractures-28.9\%. In $23(25.6 \%)$ victims, different combinations of types of TBI were simultaneously observed: bruise and compression by hematoma (10), bruise and subarachnoid hemorrhage (4), diffuse axonal injury and contusion (6), brain contusion with compression by hematoma and subarachnoid hemorrhage (3). Studies have shown that people with TBI as a result of an accident $(n=54)$ were most often bruised-26 $(48.1 \%)$ victims and concussion - $15(27.8 \%)$. Those who received TBI as a result of a fall $(n=29)$ were more likely to have fractures - $16(55.2 \%)$ and mixed injuries - $11(37.9 \%)$. 
Bruises ( $n=30)$ (contusions) and concussions $(n=33)$ of mild degree were detected respectively in $13(43.3 \%)$ and 26(78.8\%) patients, medium degree - in $15(50.0 \%)$ and 6 $(18.2 \%)$ and severe degree in $2(6.7 \%)$ and $1(3.03 \%)$ victim. Linear fractures were diagnosed in $26(28.80 \%)$ patients.

The study of damage types by GCS showed that individuals with single damage had a significantly higher average level of GCS than patients with mixed injuries.

A comparative analysis of the mean values of GCS showed that in patients with mixed lesions compared to single this indicator was statically significantly lower-by $24.1 \%(\mathrm{p}<0.05)$. The average GCS score in patients with single lesion who were also diagnosed with fractures was $7.35 \pm 1.46$ points, which was lower by $43.0 \%(p<0.01)$ and $24.9 \%(p<0.05)$, respectively, compared with single and mixed lesions. The lowest average scores were observed in patients with mixed injuries in combination with fractures - $6.42 \pm 1.33$, which was lower on average in patients with single damage and fractures by $12.7 \%$, and in comparison with single and mixed lesions by $50.2 \%(\mathrm{p}<0.01)$ and $34.4 \%(\mathrm{p}<0.05)$, respectively.

The study showed that $39(43.3 \%)$ were diagnosed with mild TBI, i.e. scores on GCS ranged from 12 to 14 points (average score - 13.14 \pm 0.84 ). The average degree of TBI was observed in $40(44.4 \%)$ patients, the indicators for GCS varied from 8 to 11 points (average score - 9.2 \pm 1.28$)$ and severe TBI - in $11(12.2 \%)$, in whom the indicators for GCS ranged from 7 to 5 points (average score $-6.36 \pm 1.27$ ).

Based on the study, it was found that the main causes of TBI were road accidents $(60.0 \%)$ and falls (32.2\%). The most frequent were concussions in 33 patients and bruises in 30 patients. 26 victims suffered linear fractures.

Computed tomography is currently the main method of assessing patients with acute TBI. An important factor is the baseline GCS. Low GCS scores were found in combination with severe TBI. Victims with TBI and low GCS scores are more susceptible to devastating effects and tend to hemodynamic instability.

Victims with mixed injuries and fractures had a low score on the Glasgow coma scale, compared to patients diagnosed with a single lesion and fracture. Therefore, the more severe the TBI, the more reduced the level of scores on GCS. Classification of severity of craniocerebral injuries as light, moderate or severe, is carried out according to the scores of GCS.

Patients with mixed trauma had an average score of $9.78 \pm 1.65$, with mixed trauma with fractures-6.42 \pm 1.03 , with single trauma-12.89 \pm 1.84 , with single trauma with fracture $-7.35 \pm 1.46$.

Thus, an initial assessment of the patient with TBI should include information about the accident, the GCS and CT scan. This is necessary to determine the cause of the injury, the intensity of the impact, the presence of neurological symptoms, seizures and, in particular, to document any loss of consciousness, the time elapsed between the accident and the examination, the presence of vomiting and seizures. CT is one of the most important methods for early diagnosis of damage in acute TBI.

$$
* * *
$$

1. Пономарева Е.Н., Сорокин А.А., Николайчик И.Р., Рухлядев И.С. и др. Легкая черепно-мозговая травма: структура и причины диагностических ошибок // Медицинские новости. 2011. №7. с.54-57.

2. Studel W.I., Cortbus F., Strowifzki M. et al. Epidemiology and prevention of total head injuries in Germany trends and the impact of the reunification // ActaNeutochirg. (Wein). 2005. vol. 147. №3. p. 231-242.

3. Imtiaz A.M. Trauma Radiology: Importance of Computed Tomography Scans In Acute Traumatic Brain Injury // International Journal of Pharmaceutical Sciences and Business Management. 2016. vol.4. Issue. 4. p. 7-15.

4. Jagdish P., Chaturbhuj S., Naima M., Meena G.L. et al. Role of Computerized Tomography in Craniocerebral Trauma // Journal of medical science and clinical research (JMSCR). 2017. vol.05. Issue 03. p. 18540-18546.

5. Singh T.S., Bhargava A., Reddy N. Significance of computed tomography scans in head injury // Open Journal of Clinical Diagnostics. 2013. vol.3. p. 109-114. 
Kazımzade J.R.

Experience of using minimally invasive interventions in infected pancreonecrosis

Azerbaijan State Institute of Advanced training of doctors named after A. Aliyev

(Azerbaijan, Baku)

doi: $10.18411 / \mathrm{gdsn}-25-12-2019-18$

idsp: scienceconf-25-12-2019-18

Acute severe pancreatitis (according to the international classification of acute pancreatitis Atlanta 1992, 2012) [1, 4, 9] occupies the third place among acute surgical diseases of the abdomen, which makes up $12.5 \%$ of all acute surgical abdominal pathologies [6]. In the structure of emergency surgical diseases of the abdominal cavity in Moscow hospitals in 2012, the share of acute pancreatitis was second only to acute appendicitis and approached $25.0 \%$ [1]. According to general surgical departments in the Russian Federation, the overall mortality in acute pancreatitis (including its mild form) remains at the level of $20.8 \%$, and in severe form it reaches $55 \%[3,6]$. Among the causes of death in patients with severe acute pancreatitis, infectious complications account for $80 \%$ [1,2]. This is mainly due to the development of severe purulent necrotic processes in the parapancreatic tissue, which do not tend to delimit, sepsis, the development of intestinal and pancreatic fistula, the progression of multiple organ failure $[2,5$, 7]. Currently, the role of minimally invasive surgical technologies, which are an important component of the complex treatment of infected pancreatic necrosis, is increasing $[1,6,7,8,10]$. They can reduce the effects of surgical stress of open interventions, stabilize the condition of patients and thereby delay the radical open surgical intervention and perform it at a more favorable time for the patient. Minimally invasive interventions can be the final method of treatment $[1,6,7,8,10]$.

Purpose of the study. Improvement of treatment results for acute severe pancreatitis complicated by infected pancreatic necrosis and retroperitoneonecrosis.

Materials and methods. On the basis of the city clinical hospital N3 in the period from 2010 to 2015 a retrospective controlled study was performed in which patients from a surgical hospital diagnosed with acute pancreatitis participated. A total of 74 patients were admitted during the indicated period.

Exclusion criteria: mild form of AP - 19 patients, patients with acute necrotizing pancreatitis, who died in the early phase of the disease, - 4 patients. Patients with acute nonbiliary ( 5 patients) and postoperative pancreatitis (1 patient), uninfected pseudocyst ( 2 patients).

Inclusion criteria: patients diagnosed with acute severe pancreatitis, infected pancreatic necrosis, associated with pathology of the biliary tract.

Patients who met the inclusion and exclusion criteria (43 people) were randomly divided (by the coin method) into two groups - the study group (21 people) and the comparison group (22 people). Patients of both groups received basic therapy: pain management, intense hydration, suppression of the external secretion of the pancreas, anti-enzyme and antibacterial therapy.

In patients of the study group, minimally invasive interventions were performed using our proposed multi-purpose drainage and a device for retroperitoneoscopy. Patients of the comparison group performed open laparotomy with program relaparotomy and lumbotomy, open drainage of the abdominal cavity and retroperitoneal tissue. We have proposed a minimally invasive modified method for the surgical treatment of infected pancreatic necrosis with videoassisted laparoscopy, bursomentoscopy and retroperitoneoscopy with drainage of purulent cavities. In this case, a number of original materials and devices are used: multifunctional fenestrated large-diameter drainages and an original four-channel device for retroperitoneoscopy.

The technique of videoassisted laparoscopy, bursomentoscopy and retroperitoneoscopy with cavitation of purulent cavities of the abdominal cavity, retrogastric space, retroperitoneal 
tissue: Laparoscopy is performed according to standard techniques. An audit of the abdominal organs is carried out, purulent exudate is evacuated from its places of accumulation. The following are the debridement of the subhepatic and / or subphrenic abscesses. Then, the opening of the retrogastric space through the gastrocolic ligament or through the small omentum at the site of greatest bulging and examination of the pancreas are performed. Purulent exudate and fibrin are removed. In the presence of formed, free-lying dense tissue sequestration, necrsecvestrectomy is necessary. After the remove of fibrinous tissue, followed by repeated washing of the abdominal cavity and retrogastric space with an antiseptic $(0.5 \%$ chlorhexidine solution). In the presence of massive, tightly fixed planar fibrinous overlays, we use transcavalinal cavitation of the abdominal cavity. The composition of the antiseptic fluid is introduced with proteolytic enzymes (trypsin, chymopsin, ronidase), which contribute to more rapid fragmentation of necrotic tissues and fibrinous deposits. Then, through punctures of the abdominal wall with trocars with a diameter of $20 \mathrm{~mm}$, a multipurpose fenestrated drainage made by us with the presence of a special "working window" of $12 \times 30 \mathrm{~mm}$ in size for subsequent dynamic therapeutic burso-omentoscopy is supplied to the anterior pancreas. For several spurs of purulent cavities, "branches" of drainage are designed in the form of tubes with holes. A similar drainage is supplied to the pancreas parallel to the first in the opposite direction. Four perforated ends of the drains are placed in the spurs of the purulent cavity, subhepatic and subphrenic spaces as necessary. The proximal ends of the drains are discharged through punctures in the projections of the sloping places of the left and right side of the abdomen. After that, through individual punctures with a diameter of $1 \mathrm{~cm}$, we introduce into the abdominal wall the three metal sleeves proposed by us for the subsequent dynamic relaparoscopy.

In infected pancreatic necrosis, a partial, and often complete purulent fusion of the pancreas occurs with the formation of an extensive purulent-necrotic process (phlegmon) of the bursa omentalis, parapancreatic and retroperitoneal tissue. In such situations, a drainage of the retroperitoneal phlegmon through the lumbar access is necessary. A mini-lumbotomy incision is made with a length of not more than $4 \mathrm{~cm}$ in the left and / or right lumbar region, at the point between the posterior and middle axillary lines. Through it, a device is introduced into the purulent cavity for retroperitoneoscopy and debridement of retroperitoneal spacer. This retroperitoneoscope designed by us has 2 wide working channels with a diameter of $20 \mathrm{~mm}$ and 2 channels of a smaller diameter. One wide channel is intended for video monitoring with a laparoscope or choledochoscope inserted into it. The second wide channel is instrumental. Channels of smaller diameter are used to supply antiseptic solutions. Under the control of a laparoscope, the posterior surface of the pancreas and its surrounding tissue are examined, pus, and dense tissue sequestration are removed. In the process of opening the parapancreatic space from the side of the abdominal cavity and parapancreatic purulent cavities from the side of the lumbar accesses, we try to create a single wide purulent cavity with the outflow of pus through the lumbar incision. In conclusion, surgical intervention through the instrumental channel of the retroperitoneoscope in the purulent cavity of the retroperitoneal parapancreatic tissue and to the posterior surface of the pancreas is provided with constant multi-purpose fenestrated drainage. A retroperitoneoscope is removed. Drainage is fixed by ligatures to the skin. Due to its wide channel with a diameter of 20 or $30 \mathrm{~mm}$, the presence of an extensive "working" window located in the purulent cavity, in the stuffing bag, in retroperitoneal fiber, multi-purpose drainages provide the possibility of daily cavitation of purulent cavities. The manipulation is almost painless and is carried out without the use of anesthesia. In addition, their design features contribute to the unimpeded outflow of exudate, pus and tissue sequestration from deep spaces. The width of the drainage canal, the shape eliminates deformation, kinks and displacement of the tube, excludes the rapid narrowing and scarring of the wound course, provides the conditions for the subsequent evacuation of pus and necrosis after removal of the drains. For more effective 
removal of dense necrotic and purulent masses from the retroperitoneal space in the postoperative period, we use overdrainage cavitation. In case of destructive pancreatitis complicated by widespread purulent peritonitis, in parallel with rehabilitation video-assisted bursomentoscopy and retroperitoneoscopy, we perform dynamic therapeutic laparoscopy with cavitation of the abdominal cavity through special drainages.

Results and discussion. In patients who underwent treatment with open debridement relaparotomy, the incidence of postoperative complications was $73.8 \%$. The number of relaparotomies in one patient is on average 7 , the mortality rate is $54.7 \%$. In the group of patients who used the minimally invasive technique, it was possible to reduce the number of complications to $31.7 \%$, mortality to $17.5 \%$, the number of relaparotomies in one patient - $1-2$, the economic cost of treating one patient minimized. The use of minimally invasive interventions for infected pancreatic necrosis reduced the length of hospital stay of patients by 1.54 times compared with open surgery methods. A feature of our proposed technique is that all medical procedures in the abdominal cavity, bursa omentalis, retroperitoneal space are minimally invasive. Visual inspection is carried out. Manipulation is performed sparingly in relation to the pancreas and surrounding tissues. Soft, flexible PVC or silicone tubes are used, while trying not to touch the surface of the gland, we perform manipulations in the washing antiseptic dialysate and through it we act on the tissue of the inflamed gland and its surrounding organs and tissues through ultrasound. Such a technique compares favorably with traditional open interventions, in which during reorganization relaparotomies and dressings, manipulations are performed that injure not only the skin, subcutaneous tissue, muscles along the postoperative wound, but also the pancreas itself and the blood vessels surrounding it.

\section{Conclusions}

1. The use of minimally invasive interventions for infected pancreatic necrosis reduced the length of hospital stay of patients by 1.54 times compared with open surgery methods.

2. Minimally invasive interventions reduced the number of postoperative complications in infected pancreatic necrosis, retroperitoneonecrosis from $73.8 \% \pm 6.8 \%$ to 31.7 $\pm 7.1 \%$, mortality from $54.7 \% \pm 7.8 \%$ to $17.5 \pm 7.0 \%$.

$$
* * *
$$

1. Banks PA, Freeman ML. Practice guidelines in acute pancreatitis. Am J Gastroenterol. 2006;101:2379-400.

2. Horvath K, Freeny P, Escallon J, et al. Safety and efficacy of video-assisted retroperitoneal debridement for infected pancreatic collections: a multicenter, prospective, single-arm phase 2 study. Arch Surg. 2010;145:817-25.

3. Shelat VG, Diddapur RK. Minimally invasive retroperitoneal pancreatic necrosectomy in necrotising pancreatitis. Singapore Med J. 2007;48:220-3.

4. Besselink MG, van Santvoort HC, Nieuwenhuijs VB, et al. Minimally invasive 'step-up approach' versus maximal necrosectomy in patients with acute necrotising pancreatitis (PANTER trial): design and rationale of a randomised controlled multicenter trial. BMC Surg. 2006;6:6.

5. van Santvoort HC, Besselink MG, Horvath KD, et al. Dutch Acute Pancreatis Study Group. Videoscopic assisted retroperitoneal debridement in infected necrotizing pancreatitis. HPB (Oxford) 2007;9:156-9.

6. Yi F, Ge L, Zhao J, et al. Meta-analysis: total parenteral nutrition versus total enteral nutrition in predicted severe acute pancreatitis. Intern Med. 2012;51:523-30.

7. Deng ZG, Zhou JY, Yin ZY, et al. Continuous regional arterial infusion and laparotomic decompression for severe acute pancreatitis with abdominal compartment syndrome. World J Gastroenterol. 2011;17:4911-6.

8. Khorsandi M, Beatson K, Dougherty S, et al. Interventional radiology in acute pancreatitis: friend or Foe? J Pancreas 2012;13:91-3.

9. Mier J, Leon E, Castillo A, et al. Early versus late necrosectomy in severe necrotzing pancreatitis. Am J Surg. 1997;173:71-5.

10. Doctor N, Philip S, Gandhi V, et al. Analysis of the delayed approach to the management of infected pancreatic necrosis. World J Gastroenterol. 2011;17:366-71. 


\title{
Mehdiyeva L.A. \\ On the issue of polycystic ovary syndrome in patients in the region of chronic iodine deficiency \\ Azerbaijan State Institute of Advanced training of doctors named after A. Aliyev (Azerbaijan, Baku)
}

doi: $10.18411 / g d s n-25-12-2019-19$

idsp: scienceconf-25-12-2019-19

\begin{abstract}
Currently, there is information about the relationship between polycystic ovary syndrome (PCOS) and thyroid pathology $[1,2]$.

In the development of PCOS, various extragenital diseases play an important role, and in the region of chronic iodine deficiency - thyroid pathology [2,3].

In this regard, it remains urgent to further study the combination of ovarian hyperandrogenism with thyroid pathology, which leads to deterioration of reproductive health and reduced fertility. A comprehensive description of this problem will help to fully study the pathogenesis of PCOS in modern conditions $[2,4]$.
\end{abstract}

Key words: polycystic ovary syndrome, hypothyroidism, iodine deficiency, history.

The aim is to assess the clinical and anamnestic characteristics of women with PCOS and thyroid dysfunction living in the region of chronic iodine deficiency.

Material and Methods. The results of the examination of 100 patients with PCOS and 20 healthy women of the control group were analyzed. Patients in the study were selected by open cohort method as they were directly treated. The first group included 60 patients with PCOS alone, the second group included 40 patients with PCOS and associated hypothyroidism. Diagnostic criteria in PCOS patients were: various disorders of menstrual function, endocrine infertility, the presence of hirsutism, clinical and/or biochemical manifestations of hyperandrogenism, echographic signs of polycystic ovaries. The severity of hirsutism was assessed on the Ferriman-Galvey scale.

Results. It was revealed that the majority of patients, both the main and control groups were women of active reproductive age from 18 to 34 years: $51(85.0 \%)$ - in the first group, 33 $(82.5 \%)$ - in the second and $18(90.0 \%)$ - in the control group. In General, overweight and obesity were more common in patients with PCOS than in women in the control group $(\mathrm{p}<0.05)$. The study of marital status showed that $75.0 \%(n=15)$ of women in the control group, $71.7 \%$ $(n=43)$ of the first and $72.5 \%(n=29)$ of the second group were married. $5(25.0 \%)$ women of the control group, $17(28.3 \%)$ patients of the first and $11(27.5 \%)$ patients of the second group were unmarried. When determining the place of residence, it was found that among all patients in the city of Sheki lived 34 (56.7\%) women of the first group, 14 (35.0\%) - the second and $7(35.0 \%)$ - the control group. In the countryside- $26(43,3 \%), 26(65,0 \%)$ and $13(65.0 \%)$ women, respectively.

Analysis of the causes of reproductive dysfunction showed that $38(63.3 \%)$ patients of the first and $30(75.0 \%)$ - the second group had infertility associated with endocrine factor. Primary infertility was indicated by $26(43.3 \%)$ and $6(15.0 \%)$ women, secondary infertility was indicated by $12(20.0 \%)$ and $24(60.0 \%)$ patients of the first and second observation groups, respectively. In the control group, there were no indications of a complicated gynecological history on the part of patients ( $\mathrm{p}<0.05)$. In the analysis of menstrual function, it was found that all women with PCOS menstrual cycle was not regular, there were violations of the type of oligomenorrhea $(\mathrm{p}<0.05)$. In women of the control group, the menstrual cycle was regular, without disorders.

Thus, taking into account the regional factor of chronic iodine deficiency, it was established that patients with PCOS and thyroid pathology had certain clinical and anamnestic features. The combined course of PCOS with hypothyroidism is observed with the greatest 
androgenization. In women with PCOS and thyroid pathology, hyperandrogenism and obesity are more marked. In turn, a burdened history of hypothyroidism causes various polycystic ovarian changes.

Conclusion. In women with PCOS with combined pathology, a burdened somatic and obstetric-gynecological history is characteristic.

$$
\text { *** }
$$

1. Conway G., Dewailly D., Diamanti-Kandarakis E. The polycystic ovary syndrome: a position statement from the European Society of Endocrinology. Eur. J. Endocrinol. 2014; 171(4): 1-29.

2. Singla R. et al. Thyroid disorders and PCOS: An emerging relationship. In.J.of End. and Metabol. 2015; 1: 25-29.

3. Зиганшин А.М., Гайсина Ю.И., Галяутдинова Г.Р. Клинические проявления синдрома поликистозных яичников. Медицинский вестник Башкортостана. 2019; 14 (1): 77-81

4. Сухоносова Е.Л. Современные взгляды на патогенез, диагностику и лечение синдрома поликистозных яичников. Дальневосточный медицинский журнал. 2015; 2: 128-133.

\section{Moskalets O.V. \\ The value of some laboratory taests as predictors of outcomes of postoperative outcomes inflammatory reactions after cataract surgery}

Moscow Regional Research Clinical Institute named after M.F.Vladimirskij

(Russia, Moscow)

doi: $10.18411 / g d s n-25-12-2019-20$

idsp: scienceconf-25-12-2019-20

Introduction. Implantation of intraocular lens (IOLs) is one of the most common operations in oftalmology. Nevertheless, the problem of exudative-inflammatory reactions (EVR) of the eye that occur after cataract surgery is still relevant. From 3.1\% to $13 \%$ patients developed this complication [1]. The period of $t$ of EVR occurance varies from several days to a month or more after surgery. The most severe manifestation is endophthalmitis, which can result in removal of the eye [4]. Prediction of the course and outcome of EVR is difficult, therefore, the search for laboratory markers that allow this to be done seems quite relevant. These tests include various markers of inflammation and endothelial disfunction, as well as autoantibody levels $[2,3,5]$.

The purpose of this study was to examine laboratory markers characteristic of various types of EVR in case of pseudophakia.

Material and methods. The study included 26 patients (10 men and 16 women) aged 17 to 75 years with an EVR that developed after phacoemulsification followed by implantation of an IOL. Laboratory studies were performed twice (on the 2-3 day after admission to the hospital and before discharg)e and included determination of the level of antibodies to double-stranded DNA (anti-DNA), soluble adhesion molecules (sICAM-1, sVCAM-1) and neopterin. The folloup period was 6 months. We used test systems from IBL (Austria), Orgentec (Germany), Bender MedSystems (Austria)

Results. EVR occurred in all patients at different times after surgery (from 2 to 14 days). The severity of EVR distribution was as follows: II degree - 12 patients $(46,1 \%)$, III degree -11 patients $(42,3 \%)$, IY degree - 3 patients $(11,3 \%)$.

The initial levels anti-DNA was increased in $14(53,8 \%)$ patients, neopterin in 11 $(42,3 \%)$, sICAM-1 in $3(11,5 \%)$, sVCAM-1 in $5(19,2 \%)$. No correlations with the timing of the development of EVR and its severity were revealed. There was a large scatter of individual indicators.

Monitoring of these indicators demonstrated, that normalization of anti-DNA levels occurred in 9 patients, while in 5 it significantly decreased compared to the initial level. At the same time, in 1 patient with severe postoperative endophthalmitis, this indicator increased even more. This fact may be due to increased apoptosis. 
In 6 patients neopterin levels decreased to normal ranges but in 2 cases it remained elevated. It should be noted that in 1 patient this indicator before discharge from the hospital increased significantly compared to the initial normal value, although the course of the disease was favorable and no complications and relapses were noted later.

Patient monitoring revealed the following. In 1 patient with endophthalmitis, the most unfavorable outcome was eye removal. At the same time, he also had the highest initial level of sVCAM-1 (3472 ng / ml), a high level of neopterin (20.6 nmol / L), both of which rapidly increased. The second patient with endophthalmitis had an initially high level of anti-DNA; before discharge, it increased by almost 5 times, but the remaining indicators practically did not exceed normal values. The course of the disease was protracted, but in the end, the outcome was favorable. Finally, in the third patient, admission showed rather high levels of antibodies to nDNA $(93.5 \mathrm{U} / \mathrm{ml})$ and neopterin $(27.7 \mathrm{ng} / \mathrm{ml})$, but by the end of treatment they returned to normal, which coincided with positive clinical dynamics. No further relapses were noted. Vision loss as the outcome of acute uveitis was associated with a high level of sICAM-1 $(610 \mathrm{ng} / \mathrm{ml})$, a moderate increase in neopterin and antibodies to nDNA upon admission. At the same time, a moderate increase in the level of sVCAM-1 was noted in the dynamics. Finally, we observed $t$ the case when a patient with acute uveitis, normal and favorable course of the postoperative period after 1.5 months developed severe endophthalmitis, requiring repeated hospitalization and prolonged drug therapy.

\section{$* * *$}

1. Belousova N.Ju. Exudative-inflammatory reaction of the eye in cataract surgery: a modern view of the problem. Modern technology in medicine. 2011. 3; 134-141(in Russ.).

2. Krichevskaya G.I., Likhvantseva V.I., Angelov V.O. The value of autoimmune reactions in the development of postoperative uveitis in patients with artifakia. Bulletin of Ophthalmology.1996. 5; 27-29 (in Russ.).

3. Moskalets O.V. Molecules of cellular adhesion ICAM-1 and VCAM-1 in infectious pathology. Pacific Medical J. 2018. 2;21-25 (in Russ.).

4. Arijeet D. Endophthalmitis after cataract surgery. Ophthalmology. 2010. 117(4); 853-859.

5. Kooij B., Rothava A., Rijkers G., deGroot Mijness J.D. Distinct cytokine and chemokine profiles in the aqueous of patients with uveitis and cystoid macular edema. AM. J. Ophthalmol. 2006. 142(1); 192194.

Petrov A.A., Sobennikova V.V.

Clinical dynamics of the problematic use of the Internet in patients with personality disorders according to a 2-year catamnestic monitoring

ANO Irkutsk Scientific and Practical Center for Medical and Social Rehabilitation of the Population

Irkutsk state medical university (Russia, Irkutsk)

doi: $10.18411 / g d s n-25-12-2019-21$

idsp: scienceconf-25-12-2019-21

\section{Abstract}

The problematic Internet use (PIU) is becoming a global medical problem. In view of the high rate of comorbidity of PIU with personality disorders (PD), there is a need for a clinical and psychopathological analysis of the dynamics of PIU in patients with PD against the background of ongoing therapy. The aim of the study was to study the dynamics of PIU in patients with PD over a 2-year follow-up taking into account the treatment. The object of the study was 43 males with PD and seeking medical help from the ANO NPC MRSN in connection with excessive use of the Internet. Within the framework of the clinical and psychopathological method, 3 PIU options were identified: Internet addiction, Internet coping - strategy for decompression and PD reactions, personality development according to the type of "digital autization". Against the background of psychotherapeutic and psychopharmacological treatment, after 6 months there was an improvement in social functioning according to the GAF scale for all three PIU variants. After 6 months, 26 people continued the therapy. According to one-year follow-up data, the 
following variants of PIU dynamics were observed - with Internet addiction: 1) Reduction of addictive symptoms with satisfactory compensation of PD 2) Relief of dependence on the background of partial compensation of RL 3) Relapse on the background of decompensation of PD 4) Autochthonous relapse; with Internet coping strategies for decompensations and reactions of PD: 1) Stopping the use of the Internet as coping due to the development of more adaptive coping mechanisms for stress 2) A significant reduction in the use of the Internet as coping due to the long-term compensation of PD 3) Continued implementation of Internet coping strategies; when developing a personality like "digital autization": 1) Leaving the digital environment as the only place for social identification with the development of adaptive strategies for social functioning 2) Prolongation of development with the formation of a state close to the Hikikomori phenomenon.

Keywords: problematic Internet use, clinical dynamics, follow-up, personality disorders, Internet addiction, coping, digital autization, decompensation, reaction

Introduction. In recent years, Internet access has become almost ubiquitous, ultimately improving the quality of life associated with communication, education, business, recreation, and many other aspects. [1] Along with the positive opportunities provided by the global network, researchers are increasingly focused on the negative consequences of Internet use [2]. The term problematic Internet use (PIU) has been known since 1995 and is attracting public attention as a new mental disorder [3-5]. PIU is characterized by poor self-control regarding Internet use, which leads to problems in school, work, family life, and other areas of social functioning [6-9]. Scientific synonyms of PIU are such terms as "Internet addiction", "compulsive Internet use", "pathological Internet use" [10]. PIU has the status of behavioral dependence, with the dependence on computer games as the most important subtype of PIU was included in section III of the DSM-5 [11]. The epidemiological indicator of PIU among adults is estimated from 4.0 to $6.2 \%$ [12-14], among adolescents-6.0\% [15].

PIU is a serious public mental health problem worldwide, and especially among young users [16]. Adolescents are particularly vulnerable to the emergence of Internet-dependent behavior, and are the subgroup of the population most exposed to the negative impact of the global network [17]. Researchers emphasize the criterion of heterogeneity of PIU, so Davis (2001) presented cognitive behavioral PIU model involving distinction between generalized problematic Internet use and specific subtypes of PIU [18]. PIU has a close association with attention deficit hyperactivity disorder, depression, anxiety, sleep disorders, impulsive control disorder and drug addiction [19-23]. An important clinical and social significance is the problem of comorbidity associated with personality disorders (PD), due to the high incidence of the latter (10.6\%) [24]. According to foreign researchers, the comorbidity rate between PIU and PD is estimated from 10.3 to $42.0 \%[25,26]$.

For PIU therapy, 3 main directions of therapeutic interventions are proposed: 1) Psychopharmacotherapy [27,28]; 2) psychotherapeutic correction [29-32] 3) Combination of psychotherapeutic techniques and drugs $[33,34]$. Despite the latter, the clinical dynamics of PIU in patients with PD observed against the background of therapeutic interventions has not been studied.

Aim of research. Study of the clinical dynamics of problem Internet use in patients with personality disorders taking into account therapeutic interventions

Material and methods. We examined 43 male patients (average age $19.6 \pm 1.8$ years) with PD seeking medical care in ANO INPC MSRN due to complaints of excessive use of the world network. PD verification was carried out on the basis of appropriate diagnostic markers ICD-10 and additional use of diagnostic test RL Dvorshchenko V. P. The typological structure of PD among the subjects was as follows: in 19 cases (44.2\%) there was schizoid PD, in 10 cases $(23.3 \%)$ - infantile PD, in 8 cases (18.6\%) - avoiding PD and in 6 cases (14.0\%) emotionally unstable PD of impulsive type. The diagnosis of PIU was carried out by means of a clinicalpsychopathological method using universal diagnostic criteria of addiction according to Griffiths M. (1996), as well as auxiliary application of the Chen scale of Internet addiction (CIAS). Evaluation of the effectiveness of therapeutic interventions was carried out using the scale of social functioning GAF. The initial processing of the obtained data was carried out using 
descriptive statistics. The Mann-Whitney U-test was used to compare psychometric differences in the values of GAF and CIAS scales in the studied cohort of patients before and after therapy. Statistical analysis was carried out through the program STATISTICA V. 10.

Results. When applying clinical psychopathological analysis among the examined contingent, 3 clinical types of PIU were verified: 1) Internet addiction (IA) (n=18) 2) Internet coping strategy in decompensation and reactions of PD $(n=12) 3)$ specific personality development according to the type of "digital autism" ( $n=13)$. In IA, excessive use of the Internet implied the presence of a full-fledged addictive symptom complex. In the case of the Internet coping strategy, the world wide web was used intensively but sporadically to compensate for affective disorders within the framework of psychopathic decompensations and reactions. At the same time, the strategy of avoiding reality was used in isolation from other components of the addictive symptom complex, which distinguished the Internet coping strategy from IA. In the case of personality development according to the type of "digital autism", a deep deformation of the cognitive - affective - behavioral motivational vector with the formation of a life style leading to social isolation and close in content to the Japanese phenomenon of "Hikikomori" was observed.

Among patients with IA, schizoid personality disorder was more often observed - 7 cases (38.9\%), in the group of patients using the Internet as coping for decompensations and reactions of PD, infantile and schizoid PD prevailed - 5 cases each (41.7\%). Schizoids (8 cases $(61,5 \%)$ ) also showed superior representation in patients with personality development, such as "digital autization" (table 1).

Table 1

The ratio of the clinical variant of PIU and the type of PD among treated patients

\begin{tabular}{|l|c|c|}
\hline \multirow{4}{*}{ Clinical variant of PIU } & Type of PD & Number of cases (abs. /\%) \\
\hline \multirow{4}{*}{ IA } & Avoiding & $3(16,7 \%)$ \\
\cline { 2 - 3 } & Schizoid & $7(38,9 \%)$ \\
\cline { 2 - 3 } & $\begin{array}{c}\text { Emotionally unstable, impulsive } \\
\text { type }\end{array}$ & $3(16,7 \%)$ \\
\cline { 2 - 3 } $\begin{array}{l}\text { Internet coping - strategy for } \\
\text { decompensations and } \\
\text { reactions of PD }\end{array}$ & Infantile & $5(27,8 \%)$ \\
\cline { 2 - 3 } $\begin{array}{l}\text { Personality development } \\
\text { according to the type of } \\
\text { "Digital Autition" }\end{array}$ & Avoiding & $2(16,7 \%)$ \\
\cline { 2 - 3 } & Schizoid & $5(41,7 \%)$ \\
\cline { 2 - 3 } & Infantile & $5(41,7 \%)$ \\
\cline { 2 - 3 } & Avoiding & $3(23,1 \%)$ \\
\hline
\end{tabular}

Taking into account the indicated 3 - component clinical typology of PIU in patients with PD, complex therapy programs were developed, including psychotherapeutic and psychopharmacological blocks (table 2).

Table 2

Structure of complex treatment programs for patients with PIU and PD

\begin{tabular}{|c|c|c|c|}
\hline & \multicolumn{3}{|c|}{ Clinical variant of PIU } \\
\hline $\begin{array}{l}\text { Component of the } \\
\text { treatment program }\end{array}$ & IA & $\begin{array}{l}\text { Internet coping strategy in } \\
\text { decompensations and } \\
\text { reactions of PD }\end{array}$ & $\begin{array}{l}\text { Development of } \\
\text { personality on the } \\
\text { type of " Digital } \\
\text { autism»" }\end{array}$ \\
\hline Psychotherapy & $\begin{array}{c}\text { Motivational interviewing } \\
+ \text { CBT for PD + CBT for } \\
\text { IA }\end{array}$ & $\begin{array}{c}\text { Motivational interviewing }+ \\
\text { CBT for PD + CBT } \\
\text { components for IA }\end{array}$ & $\begin{array}{c}\text { Motivational } \\
\text { interviewing }+ \text { CBT } \\
\text { for PD + CBT for IA }\end{array}$ \\
\hline Psychopharmacotherapy & $\begin{array}{l}\text { Valproate sodium up to } \\
500 \mathrm{mg} / \text { day., Periciazine } \\
\text { up to } 5 \mathrm{mg} / \text { day., } \\
\text { Thioridazine up to } 75 \mathrm{mg} / \\
\text { day. }\end{array}$ & $\begin{array}{l}\text { Periciazine up to } 8 \mathrm{mg} / \\
\text { day., Thioridazine up to } 75 \\
\text { mg / day., } \\
\text { Teralijen up to } 15 \mathrm{mg} / \text { day., } \\
\text { Fluvoxamine up to } 150 \\
\text { mg/day., Sertraline up to } \\
150 \mathrm{mg} / \text { day. }\end{array}$ & $\begin{array}{c}\text { Fluancsol up to } 10 \\
\text { mg/day., Periciazine } \\
\text { up to } 4 \text { mg / day., } \\
\text { Thioridazine up to } 30 \\
\text { mg/day. }\end{array}$ \\
\hline
\end{tabular}


It was noted significantly significant $(\mathrm{UEmp}=0 ; \mathrm{UCr}=25, \mathrm{p} \leq 0.01)$ reduction of the CIAS as scale in the group of patients with IA before (mean $76.8 \pm 9.8$ points) and after (mean $35.5 \pm 6.2$ points) therapy (fig. 1 ).

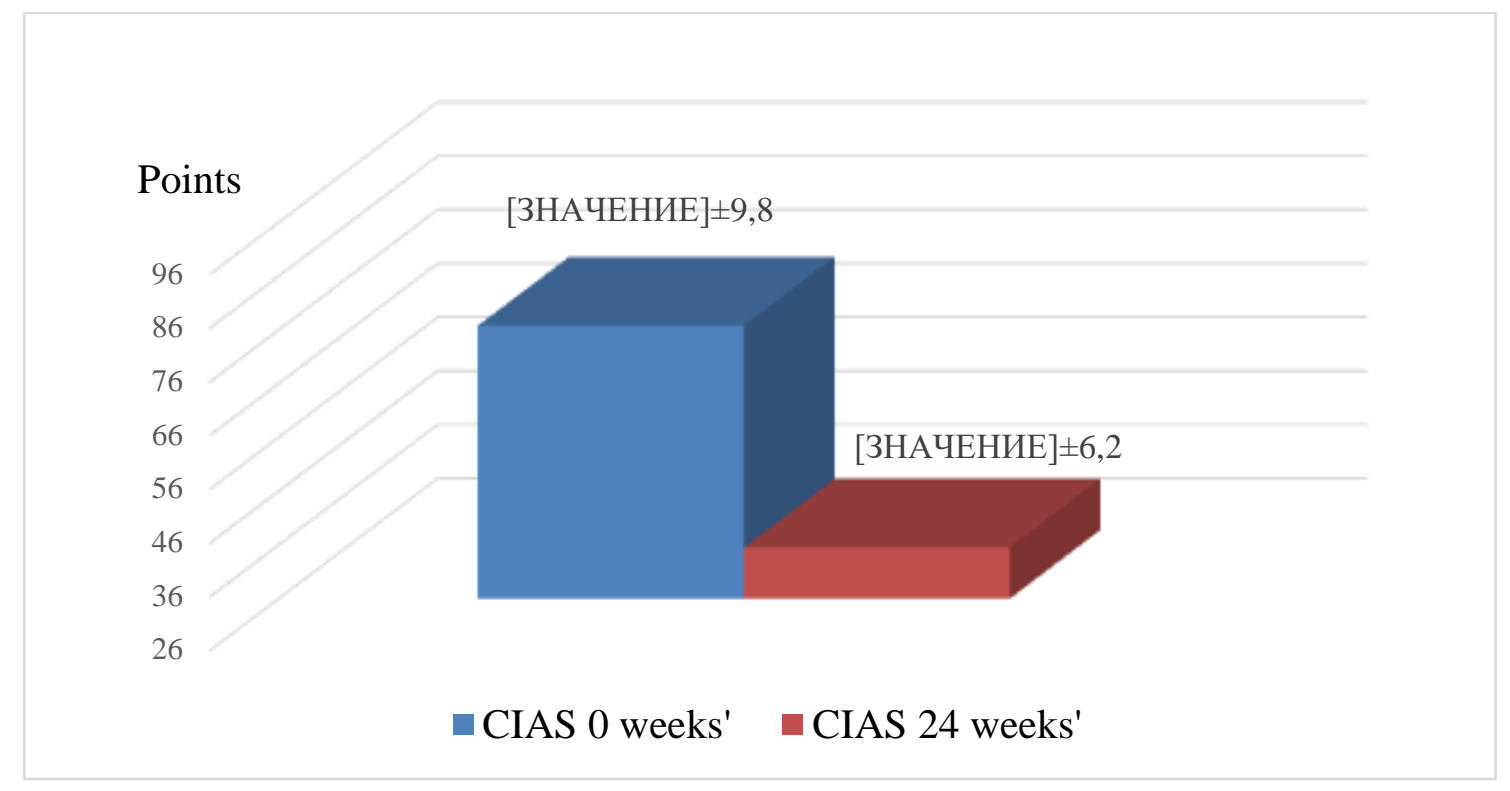

Figure 1. Dynamics of the average score CIAS scale in the group of patients with IA before and after treatment

There was a statistically significant improvement in social functioning in all 3 groups. In the group of patients with if, the average value of the GAF scale before and after treatment was $48.1 \pm 7.1$ and $67.3 \pm 4.1$ points, respectively $(\mathrm{UEmp}=0.5, \mathrm{UCr}=25, \mathrm{p} \leq 0.01)$, in the group of patients with Internet coping strategy $54.6 \pm 11.6$ and $73.5 \pm 3.4$ points, respectively (UEmp $=0.5$, $\mathrm{UCr}=19, \mathrm{p} \leq 0.01$ ), in the group with personality development by type of digital autism $43.1 \pm 8.0$ and $48.4 \pm 9.7$ points, respectively $(\mathrm{UEmp}=3.5, \mathrm{UCr}=25, \mathrm{p} \leq 0.01)$. Improvement of social functioning was noted in the overall sample $-48.4 \pm 9.7$ points before therapy and $69.2 \pm 6.2$ points after therapy $(\mathrm{UEmp}=70.5, \mathrm{UCr}=338, \mathrm{p} \leq 0.01)$ (fig.2).

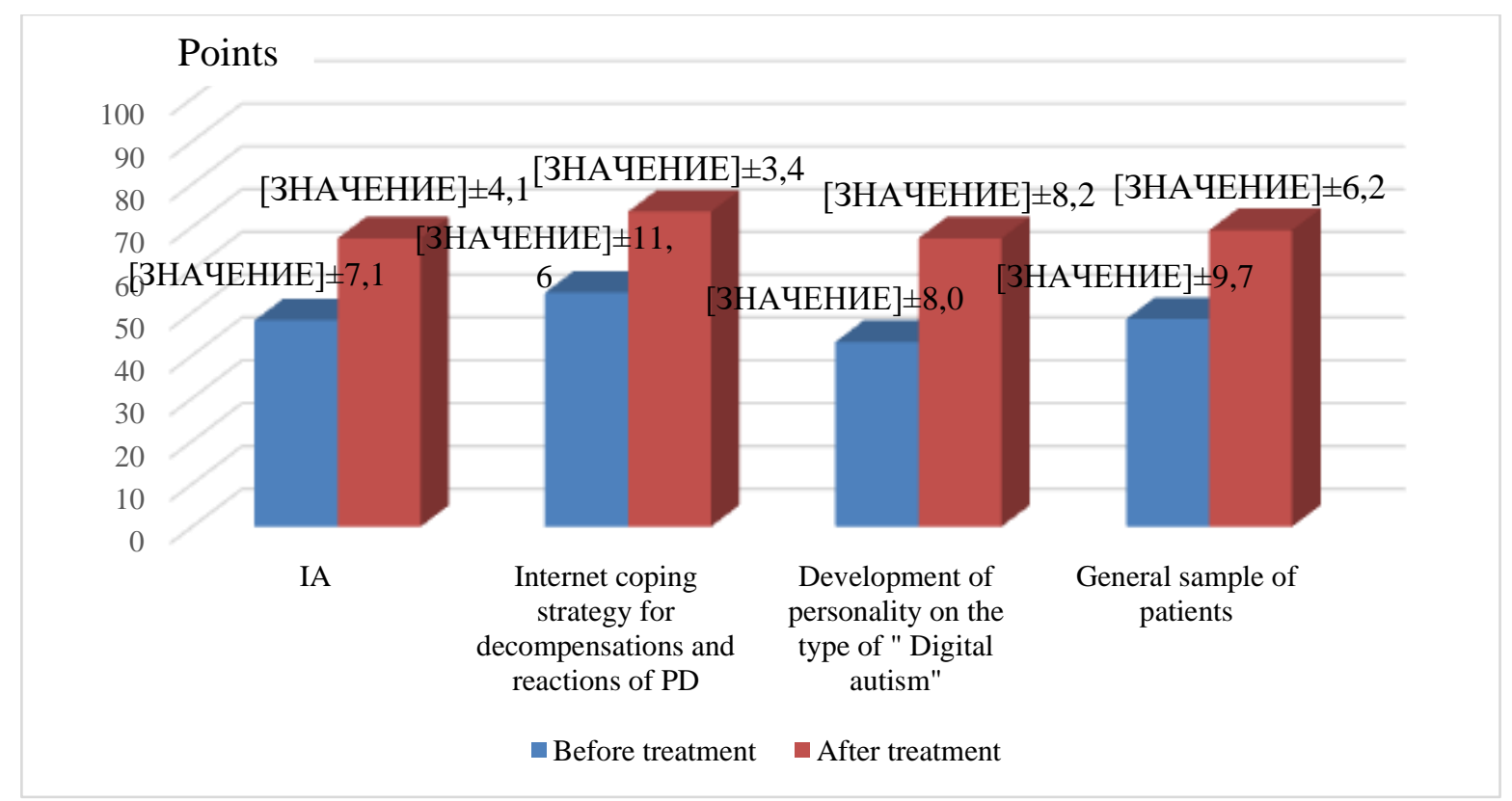

Figure 2. Dynamics of the average score of the GAF scale depending on the clinical variant of PIU in patients before and after treatment 
After the main 6 - month course of therapy, 26 people $(60.5 \%)$ continued dynamic catamnestic monitoring and treatment. Among them, 11 patients $(42.3 \%)$ with IA, 8 patients (30.8\%) used the Internet as a coping strategy for decompensation and reactions of PD and 7 patients $(26.9 \%)$ had personality development according to the type of "digital autism".

The average period of catamnesis was $1.6 \pm 0.3$ years. Therapeutic support was carried out in the form of booster sessions held 1 time in 3 months. If necessary, the issue of psychopharmacological support was discussed. The latter for patients with IA included sodium valproate + periciazine/thioridazine. Patients using the Internet as a coping strategy for decompensation and reactions of PD were recommended a combination of periciazine / thioridazine + Selective serotonin reuptake inhibitors and / or teralijen, patients with personality development of the type of "digital autism" - fluanksol and/or periciazine / thioridazine.

Taking into account the specific clinical and psychopathological interaction of PIU and PD within the framework of 2 - year catamnestic monitoring, various variants of the dynamics of problematic Internet use were determined. In IA, they were as follows: 1) Reduction of addictive symptoms with satisfactory compensation of PD -5 cases $(45.5 \%)$; 2) relaxation of dependence on the background of partial compensation of PD-2 cases (18.2\%) 3) Relapse on the background of decompensation of PD - 1 case (9.1\%) 4) Autochthonous relapse-3 cases $(27.3 \%)$ (table 2)

Table 2

Dynamics of PIU in the variant of IA according to the 2 - year catamnestic monitoring

\begin{tabular}{|c|c|c|}
\hline Options dynamics IA & Number of clinical cases \\
\cline { 2 - 3 } & abs. & $\%$ \\
\hline Reduction of addictive symptoms with satisfactory compensation of PD & 5 & 45,5 \\
\hline Relaxation of dependence on the background of partial compensation of PD & 2 & 18,2 \\
\hline Relapse on the background of decompensation of PD & 1 & 9,1 \\
\hline Autochthonous relapse & 3 & 27,3 \\
\hline
\end{tabular}

In the case of using the Internet as a coping strategy, the following variants were observed: 1) Cessation of excessive use of the Internet as a coping due to the development of more adaptive mechanisms of coping with stress - 4 cases (50.0\%) 2) Significant frequency reduction in the use of the Internet as a coping due to prolonged compensation of PD - 2 cases $(25.0 \%) 3)$ Continuation of the implementation of this coping strategy -2 cases $(25.0 \%)$ (table $3)$.

Table 3

Dynamics of PIU in the variant of coping strategies in decompensation and reactions of PD

\begin{tabular}{|l|c|c|}
\hline \multicolumn{1}{|c|}{ Dynamics of coping strategy in the form of excessive use of the Internet in } \\
decompensations and reactions of PD & \multicolumn{2}{c|}{$\begin{array}{c}\text { Number of clinical } \\
\text { cases }\end{array}$} \\
\cline { 2 - 3 } abs. & 4 & 0,0 \\
\hline $\begin{array}{l}\text { Ending the excessive use of the Internet as coping in connection with the development } \\
\text { of more adaptive mechanisms of coping with stress }\end{array}$ & 4 & 5,0 \\
\hline $\begin{array}{l}\text { A significant decrease in the frequency of Internet use as a coping due to long-term } \\
\text { compensation of PD }\end{array}$ & 2 & 5,0 \\
\hline Continued implementation of the Internet coping strategy & 2 & 2 \\
\hline
\end{tabular}

In the development of RL type "digital autism" there were such clinical options as: 1) Exit from the digital environment as the only place of social identification with the development of adaptive strategies of social functioning in real society 2) Prolongation of development with the formation of a state in its content close to the Asian phenomenon "Hikikomori", implying a complete rejection of real social life with the use of digital devices to ensure minimal life needsIn the development of RL type "digital autism" there were such clinical options as: 1) Exit from the digital environment as the only place of social identification with the development of adaptive strategies of social functioning in real society 2) Prolongation of development with the formation of a state in its content close to the Asian phenomenon "Hikikomori", implying a complete rejection of real social life with the use of digital devices to ensure minimal life needs (Table 4). 
Dynamics of PIU in the variant of personality development according to the type of «digital autism»

\begin{tabular}{|l|c|c|}
\hline \multirow{2}{*}{ Dynamics of personality development by the type of " Digital autism» } & \multicolumn{2}{c|}{ Number of clinical cases } \\
\cline { 2 - 3 } & Abs. & $\%$ \\
\hline $\begin{array}{l}\text { Exit from the digital environment as the only place of social identification } \\
\text { with the development of adaptive strategies of social functioning in real } \\
\text { society }\end{array}$ & 4 & 57,1 \\
\hline $\begin{array}{l}\text { Prolongation of development with the formation of a state close to the } \\
\text { phenomenon of "Hikikomori» }\end{array}$ & 3 & 42,9 \\
\hline
\end{tabular}

Conclusion. According to the results of the analysis of 2-year catamnestic follow-up, the overall positive dynamics of PIU was observed in 17 patients $(65.4 \%)$ ). Despite this positive trend, further research is needed to develop and test highly effective regimens for complex therapy of problematic Internet use in patients with personality disorders. Such work will have a significant role in improving the quality of life and increase the social adaptability of pathological Internet users.

$$
\text { *** }
$$

1. Sakakihara, A., Haga, C., \& Osaki, Y. (2019). Association Between Mothers' Problematic Internet Use and the Thinness of Their Children. Cyberpsychology, Behavior, and Social Networking, 22(9), 578-587.

2. Kitazawa, M., Yoshimura, M., Murata, M., Sato-Fujimoto, Y., Hitokoto, H., Mimura, M., ... \& Kishimoto, T. (2018). Associations between problematic Internet use and psychiatric symptoms among university students in Japan. Psychiatry and clinical neurosciences, 72(7), 531-539.

3. Laconi, S., Rodgers, R. F., \& Chabrol, H. (2014). The measurement of Internet addiction: A critical review of existing scales and their psychometric properties. Computers in human behavior, 41, 190-202.

4. Lopez-Fernandez, O., Freixa-Blanxart, M., \& Honrubia-Serrano, M. L. (2013). The problematic Internet entertainment use scale for adolescents: prevalence of problem Internet use in Spanish high school students. CyberPsychology, Behavior, and social networking, 16(2), 108-118.

5. Nikolaidou, M., Fraser, D. S., \& Hinvest, N. (2016). Physiological markers of biased decision-making in problematic Internet users. Journal of behavioral addictions, 5(3), 510-517.

6. Shapira, N. A., Lessig, M. C., Goldsmith, T. D., Szabo, S. T., Lazoritz, M., Gold, M. S., \& Stein, D. J. (2003). Problematic internet use: proposed classification and diagnostic criteria. Depression and anxiety, 17(4), 207216.

7. Paik, A., Oh, D., \& Kim, D. (2014). A case of withdrawal psychosis from internet addiction disorder. Psychiatry investigation, 11(2), 207.

8. Kaur J. S., Bhatia M. S., GautaM P. K. Internet sex addiction and its negative consequences: a report //Journal of clinical and diagnostic research: JCDR. - 2015. - T. 9. - №. 2. - C. VL01.

9. Morrison, C. M., \& Gore, H. (2010). The relationship between excessive Internet use and depression: a questionnaire-based study of 1,319 young people and adults. Psychopathology, 43(2), 121-126.

10. Liu, T., \& Potenza, M. N. (2007). Problematic Internet use: clinical implications. CNS spectrums, 12(6), 453466.

11. King, D. L., \& Delfabbro, P. H. (2014). Internet gaming disorder treatment: a review of definitions of diagnosis and treatment outcome. Journal of Clinical Psychology, 70(10), 942-955.

12. Bakken, I. J., Wenzel, H. G., Götestam, K. G., Johansson, A., \& Øren, A. (2009). Internet addiction among Norwegian adults: a stratified probability sample study. Scandinavian journal of psychology, 50(2), 121-127.

13. Zadra, S., Bischof, G., Besser, B., Bischof, A., Meyer, C., John, U., \& Rumpf, H. J. (2016). The association between Internet addiction and personality disorders in a general population-based sample. Journal of Behavioral Addictions, 5(4), 691-699.

14. de Vries, H. T., Nakamae, T., Fukui, K., Denys, D., \& Narumoto, J. (2018). Problematic internet use and psychiatric co-morbidity in a population of Japanese adult psychiatric patients. BMC psychiatry, 18(1), 9.

15. Cheng, C., \& Li, A. Y. L. (2014). Internet addiction prevalence and quality of (real) life: A meta-analysis of 31 nations across seven world regions. Cyberpsychology, Behavior, and Social Networking, 17(12), 755-760.

16. Christakis, D. A. (2010). Internet addiction: a 21 st century epidemic?. BMC medicine, 8(1), 61.

17. Grant, J. E., Potenza, M. N., Weinstein, A., \& Gorelick, D. A. (2010). Introduction to behavioral addictions. The American journal of drug and alcohol abuse, 36(5), 233-241.

18. Davis, R. A. (2001). A cognitive-behavioral model of pathological Internet use. Computers in human behavior, 17(2), 187-195.

19. Liu, C. Y., \& Kuo, F. Y. (2007). A study of Internet addiction through the lens of the interpersonal theory. CyberPsychology \& Behavior, 10(6), 799-804. 
20. Murray C. J. L. et al. Global, regional, and national disability-adjusted life years (DALYs) for 306 diseases and injuries and healthy life expectancy (HALE) for 188 countries, 1990-2013: quantifying the epidemiological transition //The Lancet. - 2015. - T. 386. - №. 10009. - C. 2145-2191.

21. Young, K. S., \& Rogers, R. C. (1998). The relationship between depression and Internet addiction. Cyberpsychology \& behavior, 1(1), 25-28.

22. Treuer, T., Fábián, Z., \& Füredi, J. (2001). Internet addiction associated with features of impulse control disorder: is it a real psychiatric disorder? Journal of Affective disorders, 66(2-3), 283.

23. Younes, F., Halawi, G., Jabbour, H., El Osta, N., Karam, L., Hajj, A., \& Khabbaz, L. R. (2016). Internet addiction and relationships with insomnia, anxiety, depression, stress and self-esteem in university students: A cross-sectional designed study. PloS one, 11(9), e0161126.

24. Lenzenweger M. F. Epidemiology of personality disorders //Psychiatric Clinics of North America. - 2008. T. 31. - №. 3. - C. 395-403. - 24

25. Müller, K. W., Beutel, M. E., \& Wölfling, K. (2014). A contribution to the clinical characterization of Internet addiction in a sample of treatment seekers: Validity of assessment, severity of psychopathology and type of co-morbidity. Comprehensive Psychiatry, 55(4), 770-777.

26. Floros, G., Siomos, K., Stogiannidou, A., Giouzepas, I., \& Garyfallos, G. (2014). Comorbidity of psychiatric disorders with Internet addiction in a clinical sample: The effect of personality, defense style and psychopathology. Addictive behaviors, 39(12), 1839-1845.

27. Han, D. H., Lee, Y. S., Na, C., Ahn, J. Y., Chung, U. S., Daniels, M. A., ... \& Renshaw, P. F. (2009). The effect of methylphenidate on Internet video game play in children with attention-deficit/hyperactivity disorder. Comprehensive psychiatry, 50(3), 251-256.

28. Bipeta, R., Yerramilli, S. S., Karredla, A. R., \& Gopinath, S. (2015). Diagnostic stability of Internet addiction in obsessive-compulsive disorder: Data from a naturalistic one-year treatment study. Innovations in clinical neuroscience, 12(3-4), 14.

29. Young, K. S. (2007). Cognitive behavior therapy with Internet addicts: treatment outcomes and implications. CyberPsychology \& Behavior, 10(5), 671-679.

30. Young, K. S. (2013). Treatment outcomes using CBT-IA with Internet-addicted patients. Journal of Behavioral Addictions, 2(4), 209-215.

31. Вострокнутов, Н. В., \& Пережогин, Л. О. (2009). Зависимость от персонального компьютера, компьютерных игр и интренета в детской психиатрической практике. Практическая медицина, (38).

32. Liu, Q. X., Fang, X. Y., Yan, N., Zhou, Z. K., Yuan, X. J., Lan, J., \& Liu, C. Y. (2015). Multi-family group therapy for adolescent Internet addiction: Exploring the underlying mechanisms. Addictive Behaviors, 42, 18 .

33. Han, D. H., \& Renshaw, P. F. (2012). Bupropion in the treatment of problematic online game play in patients with major depressive disorder. Journal of Psychopharmacology, 26(5), 689-696.

34. Santos, V., Egidio Nardi, A., \& Lucia Spear King, A. (2015). Treatment of internet addiction in patient with panic disorder and obsessive compulsive disorder: a case report. CNS \& Neurological Disorders-Drug Targets (Formerly Current Drug Targets-CNS \& Neurological Disorders), 14(3), 341-344. 


\title{
РАЗДЕЛ ІV. БИОЛОГИЯ
}

\author{
Шишелова А.Ю. ${ }^{1,2}$, Смирнов К.С. ${ }^{2}$ \\ Влияние ранней социальной изоляции на поведение во взрослом возрасте зависит \\ от критического периода постнатального онтогенеза \\ ${ }^{1}$ Российский национальньй исследовательский медицинский университет имени Н. И. \\ Пирогова \\ ${ }^{2}$ ФГБУН Институт высшей нервной деятельности и нейрофизиологии РАН \\ (Россия, Москва)
}

doi: $10.18411 / g d s n-25-12-2019-22$

idsp: scienceconf-25-12-2019-22

\section{Abstract}

The effect of complete social deprivation in the critical periods of early postnatal ontogenesis on adult behavior in Wag/Rij rats with a genetic predisposition to the absence epilepsy was studied. It was found that a 3-hour daily social isolation of rat pups from the mother and siblings in early postnatal ontogenesis affects the exploratory behavior and learning conditioned response in adulthood. Adult rats behavior was tested in the elevated plus-maze, the open field and during the learning of two-way active avoidance in the "shuttle box". The effect of social deprivation depends on the social period of ontogeny. The isolation in the second week of postnatal life (from 9th to 15th day) led to an increase in emotional reactivity to a new environment, an increase in exploratory behavior in a threatening space of the elevated plusmaze, and an increase in the ability to learn a conditioned response. The isolation in the third week of life (from 16th to 22nd day) led to a more pronounced increase in locomotor and exploratory activity in a potentially dangerous open space of the elevated plus-maze and the open field, without causing changes in anxiety and the ability to learn a conditioned response. Thus, the second and third weeks of postnatal ontogeny are characterized by different sensitivity to social influences for subsequent development of exploratory behavior and learning ability.

Развитие новорожденного и формирование его поведения в значительной степени зависит от социальной среды [Pryce, Feldon, 2003; Curley J.P. et al, 2011]. В раннем постнатальном онтогенезе наиболее значимые источники видоспецифических сенсорных сигналов - это мать и сиблинги [Шишелова А.Ю., Раевский В.В., 2016; Шишелова А.Ю., Раевский В.В., 2018; Шишелова А.Ю., Раевский В.В., 2019, Friedman E. et al., 2006; Tang A.C. et al., 2014]. Эпигенетическое влияние социальных факторов на развитие новорожденного зависит от периода онтогенеза [Шишелова А. Ю., Раевский В.В., 2009; Шишелова А.Ю., Раевский В.В., 2019]. Так, у крыс в первую неделю жизни двигательная активность детенышей снижена, и в этот период жизни активное социальное поведение у них проявляется преимущественно в контакте с матерью во время сосания и вылизывания. С 9-го дня жизни увеличивается уровень социальных коммуникаций в гнезде, начинается развитие взаимного груминга и игровых реакций между сиблингами, сопровождающееся формированием целенаправленных движений вибрисс («whisking») [Grant R.A., 2012; Pellis S.M., Pellis V.C., 1997]. Изменение социальной среды в этот период может быть более критичным для последующих процессов развития по сравнению с воздействием в первые дни постнатального онтогенеза. Показано, что нарушение видоспецифической афферентации путем удаления вибрисс с 9-го по 20-й дни жизни оказывает более сильное влияние на синхронность развития ранних поведенческих реакций по сравнению с депривацией со 2-го дня жизни [Шишелова А. Ю., Раевский В.В., 2009]. Было обнаружено, что при вибриссэктомии со 2-го дня жизни происходят перестройки в созревании функциональных систем поведенческих реакций с более интенсивным включением зрительной афферентации для их сенсорного обеспечения, что может приводить к компенсации недостатка информации от вибрисс [Шишелова А. Ю., Раевский В.В., 2009]. Таким образом, после прозревания, происходящего у интактных крысят в возрасте 15-16 дней, зрительная афферентация может стать ведущей для 
интеграции функциональных систем развивающихся в этот период поведенческих актов: стоек, груминга, манипуляторной активности, составляющих основу социального и исследовательского поведения. С этого же возраста значительно возрастают двигательная активность, коммуникации между сиблингами и игровое поведение [Auger A.P., Olesen K.M., 2009; Himmler B. T. et al., 2015]. Это создает основание для разделения периода социализации раннего постнатального онтогенеза на два: до открытия глаз (9-15 дни) и после (с 16-го дня жизни). Целью работы было оценить влияние неблагоприятных социальных факторов во вторую и третью недели раннего постнатального онтогенеза на поведение и способность к обучению потомства крыс линии WAG/Rij с врожденной предрасположенностью к абсанс эпилепсии. Мы предполагаем, что изменение социальной среды в семье особей с врожденной патологией головного мозга может оказывать положительное воздействие на формирование поведения у детенышей.

В качестве модели социальной депривации нами была использована полная социальная изоляция, когда каждого детеныша содержали отдельно от матери и сиблингов. В экспериментальных группах крысят линии WAG/Rij подвергали ежедневной изоляции в течение 3-х часов: в первой группе с 9-го по 15-й день (4 помета), во второй группе - с 16-го по 22-й день постнатального онтогенеза (5 пометов). В контрольной группе проводили только осмотр крысят в возрасте 2-х и 9-ти дней (6 пометов). В возрасте 27 дней крысят отсаживали от матери и далее содержали группами по 3-4 животных в каждой клетке. В возрасте 2 мес. тестировали поведение самцов в приподнятом крестообразном лабиринте, через 2 нед. - в «открытом поле». Двигательную и исследовательскую активность оценивали с помощью видеотрекинга: в приподнятом крестообразном лабиринте (ПКЛ) в течение пяти минут, в «открытом поле» в течение десяти минут. После 5 месяцев жизни, когда у большинства крыс WAG/Rij появляется заметная эпилептическая активность, проводили тестирование когнитивных способностей путем обучения условному рефлексу двустороннего избегания (УРДИ) в челночной камере.

Были получены следующие результаты. В ПКЛ по большинству показателей двигательной и вертикальной активности в закрытых коридорах и на центральной площадке не было выявлено отличий экспериментальных групп от контрольной. Обнаружено только статистически значимое влияние воздействия в раннем онтогенезе на длину пути в закрытых коридорах $(\mathrm{F}(2,50)=4,90, \mathrm{p}=0,011)$ и число свешиваний с центральной площадки $(\mathrm{F}(2,50)=11.17, \mathrm{p}=0,0001)$. Post-hoc анализ показал, что крысы, изолированные с 9-го дня, проходят большее расстояние в закрытых коридорах по сравнению с другими группами (табл. 1). В обеих экспериментальных группах наблюдалось большее число свешиваний, чем в контрольной (табл. 1).

Табл. 1.

Показатели поведения в закрытых коридорах и на иентральной площадке ПКЛ крыс контрольной и экспериментальных групп (среднее \pm С.К.О.)

\begin{tabular}{|l|c|c|c|}
\hline \multicolumn{1}{|c|}{ Показатели поведения } & $\begin{array}{c}\text { Контрольная } \\
\text { группа } \\
n=19\end{array}$ & $\begin{array}{c}\text { Изолированные } \\
\text { с 9-го дня жизни } \\
n=15\end{array}$ & $\begin{array}{c}\text { Изолированные } \\
\text { с 16-го дня жизни } \\
n=19\end{array}$ \\
\hline $\begin{array}{l}\text { Длина пути в закрытых } \\
\text { коридорах, см }\end{array}$ & $886,6 \pm 182,0$ & $\begin{array}{c}1006,6 \pm 208,5 \\
* p=0,048 \\
@ p=0,007\end{array}$ & $818,6 \pm 133,2$ \\
\hline $\begin{array}{l}\text { Число свешиваний из } \\
\text { центральной площадки (среднее } \\
\text { за мин пребыва-ния в этой зоне) }\end{array}$ & $4,26 \pm 1,27$ & $\begin{array}{c}8,12 \pm 2,98 \\
* p=0,0002\end{array}$ & $\begin{array}{c}6,59 \pm 2,76 \\
* p=0,006\end{array}$ \\
\hline Число актов груминга & $0,89 \pm 0,99$ & $\begin{array}{c}1,73 \pm 1,03 \\
\# p=0,018\end{array}$ & $1,47 \pm 1,26$ \\
\hline доля крыс с дефекациями, \% & $26 \%$ & $\begin{array}{c}67 \% \\
\& p=0,017\end{array}$ & $33 \%$ \\
\hline
\end{tabular}

Обозначения: * - отличие от контрольной группь, @ - отличие от другой экспериментальной группь (ANOVA, post-hoс анализ, Newman-Keuls test)

\# - отличие от контрольной группь, тест Манна-Уитни,

\& - отличие от контрольной группь, two-side тест сравнения двух пропорций 
В открытых коридорах у крыс, изолированных с 9-го дня жизни, статистически значимо увеличивались средняя длина пути, пройденного во время одного выхода в открытый коридор, по сравнению с контрольной группой (табл. 2). Других статистически значимых отличий этой группы от контрольной не было обнаружено. У крыс, изолированных с 16-го дня жизни, по сравнению с контрольной группой происходило статистически значимое увеличение большинства показателей поведения в открытых коридорах: длины пути, времени пребывания, максимальной скорости перемещения, средней длины пути, пройденного за каждый выход в открытый коридор (табл. 2), что свидетельствует о повышении исследовательской активности в опасном пространстве.

Табл. 2.

Показатели поведения в открытых коридорах ПКЛ крыс контрольной и экспериментальных групп (среднее \pm C.К.О.)

\begin{tabular}{|l|c|c|c|}
\hline \multicolumn{1}{|c|}{$\begin{array}{c}\text { Показатели поведения в } \\
\text { открытых коридорах }\end{array}$} & $\begin{array}{c}\text { Контрольная } \\
\text { группа } n=13\end{array}$ & $\begin{array}{c}\text { Изолированные с 9-го } \\
\text { дня жизни } n=10\end{array}$ & $\begin{array}{c}\text { Изолированные с 16- } \\
\text { го дня жизни } n=16\end{array}$ \\
\hline Длина пути, см & $114,9 \pm 76,7$ & $175,2 \pm 83,6$ & $\begin{array}{c}232,4 \pm 130,8 \\
* p=0,006\end{array}$ \\
\hline Время пребывания, с & $32,2 \pm 21,9$ & $52,8 \pm 30,0$ & $\begin{array}{c}60,2 \pm 30,4 \\
* p=0,009\end{array}$ \\
\hline $\begin{array}{l}\text { Средняя длина пути, } \\
\text { пройденного за один выход, см }\end{array}$ & $50,1 \pm 29,2$ & $\begin{array}{c}70,0 \pm 24,5 \\
* p=0,028\end{array}$ & $\begin{array}{c}72,45 \pm 30,05 \\
* p=0,046\end{array}$ \\
\hline Vmax, см/с & $16,0 \pm 5,4$ & $18,75 \pm 4,2$ & $\begin{array}{c}22,4 \pm 7,9 \\
* p=0,013\end{array}$ \\
\hline
\end{tabular}

Обозначения: * - отличие от контрольной группь (тест Манна-Уитни)

У крыс, изолированных с 9-го дня жизни, показатели эмоциональной реактивности и тревожности в новой обстановке - число актов груминга и число крыс с дефекациями были статистически значимо больше по сравнению с контрольными животными (табл. 1). Вторая экспериментальная группа не отличалась от контрольной по этим показателям.

Таким образом, изоляция с 9-го по 15-й дни жизни приводила к увеличению эмоциональной реактивности на новую обстановку во взрослом возрасте и увеличение отдельных показателей исследовательской активности во всех отсеках лабиринта. Изоляция с 16-го дня жизни оказывала наиболее выраженное влияние на поведение в открытых коридорах ПКЛ во взрослом возрасте, вызывая значительное увеличение большинства показателей исследовательской активности.

В «открытом поле» обнаружено статистически значимое влияние изоляции на длину пути (анализ ANOVA, $\left.\mathrm{F}_{(2,49)}=7,724, \mathrm{p}=0,0012\right)$, время «сидения» $\mathrm{F}_{(2,49)}=8,087$, $\mathrm{p}=0,0009)$, среднюю скорость перемещения $\left(\mathrm{F}_{(2,49)}=9,3704, \mathrm{p}=0,0004\right)$. Post-hoc анализ показал, что крысы, изолированные с 16-го дня жизни, имели более высокую двигательную активность по сравнению с другими группами (табл. 3). Также у животных, изолированных в более поздний период, происходило увеличение исследовательской активности (длины пути и $V \max$ в центральной зоне, числа стоек), и числа актов груминга (табл. 3). Поведение крыс из первой экспериментальной группы не отличалось от контрольной, за исключением увеличения числа актов груминга (табл. $3)$.

Таким образом, изоляция с 9-го дня жизни не оказывала влияния на исследовательское поведение в «открытом поле» у взрослых крыс, в то время как изоляция с 16-го дня жизни вызывала выраженное увеличение двигательной и исследовательской активности в этом тесте.

При обучении УРДИ у крыс, подвергавшихся изоляции с 9-го дня жизни, зарегистрировано повышение способности к обучению. Так, критерия обученности (наличие 9 условных реакций в ответ на 10 последовательных предъявлений условного 
стимула) не достигли 52\% контрольных крыс, 17\% крыс 1-й экспериментальной группы (отличие от контрольной группы статистически значимо, $\mathrm{p}=0,046$, two-side тест сравнения двух пропорций), 50\% крыс 2-й экспериментальной группы. У животных 1-й экспериментальной группы также были статистически значимо больше число условных реакций $(52,6 \pm 18,3 \%$ от 50 сочетаний $)$ и максимальное число условных реакций, наблюдавшихся подряд $(11,9 \pm 7,0)$ по сравнению с контрольной группой $(36,2 \pm 21.8 \%$ и 6,9 \pm 5.8 соответственно, критерий Манна-Уитни, $\mathrm{p}=0,033$ и $\mathrm{p}=0,026)$. Остальные показатели обучения УРДИ не различались у контрольных и экспериментальных животных. Таким образом, социальная изоляция во вторую неделю жизни приводит к увеличению способности к обучению УРДИ во взрослом возрасте, а изоляция на третьей неделе жизни не оказывает влияния на обучение условному рефлексу.

Таблища 3.

Показатели поведения в «открытом поле» контрольных и экспериментальных крыс (среднее значение \pm С.К.О.)

\begin{tabular}{|l|c|c|c|}
\hline \multicolumn{1}{|l|}{ Показатели поведения } & $\begin{array}{c}\text { Контрольная группа } \\
n=19\end{array}$ & $\begin{array}{c}\text { Изолированные } \\
\text { с 9-го дня жизни } \\
n=16\end{array}$ & $\begin{array}{c}\text { Изолированные } \\
\text { с 16-го дня жизни } \\
n=17\end{array}$ \\
\hline Длина пути, см & $2998,2 \pm 1008,4$ & $3116,8 \pm 799,9$ & $\begin{array}{c}4019,9 \pm 635.5 \\
* p=0,002 \\
@ p=0,003\end{array}$ \\
\hline $\begin{array}{l}\text { Время } \\
\text { «сидения», с }\end{array}$ & $308,4 \pm 79.2$ & $303,9 \pm 59.2$ & $\begin{array}{c}233,9 \pm 32.7 \\
* p=0,002 \\
@ p=0,0016\end{array}$ \\
\hline $\begin{array}{l}\text { Средняя скорость } \\
\text { перемещения, см/с }\end{array}$ & $5,05 \pm 1,6$ & $5,3 \pm 1.4$ & $\begin{array}{c}6,9 \pm 1.0 * \\
p=0,008\end{array}$ \\
\hline $\begin{array}{l}\text { Длина пути в } \\
\text { центральной зоне, см }\end{array}$ & $69,3 \pm 75.2$ & $140,2 \pm 146.5$ & $\begin{array}{c}286,5 \pm 134.3 \\
\# p=0,00002\end{array}$ \\
\hline $\begin{array}{l}\text { Утах в центральной } \\
\text { зоне, см/с }\end{array}$ & $21,5 \pm 11.7$ & $24,9 \pm 9.8$ & $\begin{array}{c}32,5 \pm 7.3 \\
\# p=0,0048\end{array}$ \\
\hline Число стоек & $10,16 \pm 5.08$ & $10,13 \pm 4.92$ & $\begin{array}{l}15,29 \pm 4.77 \\
\# p=0,0042\end{array}$ \\
\hline Число актов груминга & $2,47 \pm 1.81$ & $\begin{array}{l}5,63 \pm 1.96 \\
\# \mathrm{p}=0,0001\end{array}$ & $\begin{array}{c}5,0 \pm 3.28 \\
\# p=0,0072\end{array}$ \\
\hline
\end{tabular}

Обозначения: * - отличие от контрольной группь, @ - отличие от другой экспериментальной группь (ANOVA, post-hoc, Newman-Keuls test, для показателей, имевших нормальное распределение); \# - отличие от контрольной группь (тест Манна-Уитни, для показателей, имевиих отличное от нормального распределение).

Заключение. Ежедневная социальная депривация особей с генетической предрасположенностью к абсанс эпилепсии путем полной изоляции от матери и сиблингов в раннем постнатальном онтогенезе влияет на исследовательское поведение и способность к обучению во взрослом возрасте. Характер влияния социальной депривации зависит от периода онтогенеза. Депривация на второй неделе жизни приводит к увеличению эмоциональной реактивности на новую обстановку во взрослом возрасте, повышению исследовательской активности в угрожающем пространстве при наличии выбора между опасной и безопасной зонами и увеличению способности к обучению условному рефлексу избегания болевого раздражения. Депривация на третьей неделе жизни приводит к более выраженному повышению двигательной и исследовательской активности в потенциально угрожающем открытом 
пространстве, не вызывая изменений тревожности и способности к обучению условному рефлексу с болевым подкреплением.

\author{
Работа поддержана грантом РФФИ № 18-013-00597 «Социальные факторы, \\ аггравирующие проявление абсанс-эпилепсии». \\ $* * *$
}

1. Шишелова А. Ю., Раевский В.В. Влияние вибриссэктомии в раннем постнатальном онтогенезе у крысят на развитие поведения. Журнал высшей нервной деятельности. 2009. Т. 59. № 3. С. 326 - 334.

2. Шишелова А.Ю., Раевский В.В. Влияние опыта материнства на формирование видоспецифического поведения потомства в раннем онтогенезе. Журнал эволюционной биохимии и физиологии. 2016. Т.52. № 5. C. 347-353.

3. Шишелова А.Ю., Раевский В.В. Влияние пре- и постнатальных факторов на формирование ранних поведенческих реакций. ДОКЛАДЫ АКАДЕМИИ НАУК. 2018, том 479, № 3, с. 351-353.

4. Шишелова А.Ю., Раевский В.В. Социальная среда раннего онтогенеза и формирование исследовательского поведения в зрелом возрасте. Экспериментальная психология. 2019. Т.12. №3 с. 142-147.

5. Auger A.P., Olesen K.M. Brain sex differences and the organisation of juvenile social play behaviour. J Neuroendocrinol. 2009. V. 21. № 6. P. 519-525. doi: 10.1111/j.1365-2826.2009.01871.x.

6. Curley J.P., Jensen C.L., Mashoodh R., Champagne F.A. Social influences on neurobiology and behavior: epigenetic effects during development. Psychoneuroendocrinology, 2011. V. 36. № 3. P. 352-371. doi: 10.1016/j.psyneuen.2010.06.005.

7. Friedman E., Berman M., Overstreet D. Swim test immobility in a genetic rat model of depression is modified by maternal environment: a cross-foster study. Dev Psychobiol. 2006. V.48. № 2. P. 169-177.

8. Grant R.A., Mitchinson B., Prescott T.J. The development of whisker control in rats in relation to locomotion. Developmental Psychobiology. 2012. V. 54. № 2. P. 151-168. doi: 10.1002/dev.20591.

9. Himmler B. T., Himmler S. M., Stryjek R., Modlińska K., Pisula W., Pellis S.M. The Development of Juvenile-Typical Patterns of Play Fighting in Juvenile Rats does not Depend on Peer-Peer Play Experience in the Peri-Weaning Period. International Journal of Comparative Psychology. 2015. V.28. P. 1-18.

10. Pellis S.M., Pellis V.C. The prejuvenile onset of play fighting in laboratory rats (Rattus norvegicus). Dev. Psychobiol. 1997. V. 31. № 3. P. 193-205.

11. Pryce C.R., Feldon J. Long-term neurobehavioural impact of the postnatal environment in rats: manipulations, effects and mediating mechanisms. Neurosci Biobehav Rev. 2003. V. 27. № 1-2. P. 57-71.

12. Tang A.C., Reeb-Sutherland B.C., Romeo R.D., McEwen B.S. On the causes of early life experience effects: evaluating the role of mom. Front Neuroendocrinol. 2014. V.35. № 2. P. 245-251. doi: 10.1016/j.yfrne.2013.11.002.

\title{
Шишелова А.Ю. ${ }^{1}$, Алексанян О.В. ${ }^{2}$ \\ Формирование поведения крыс линии WAG/Rij зависит от материнской заботы в раннем постнатальном онтогенезе
}

${ }^{1}$ Российский нацуиональный исследовательский медицинский университет имени Н. И. Пирогова

${ }^{2}$ Московский государственный медико-стоматологический университет имени А.И. Евдокимова doi: $10.18411 / g d s n-25-12-2019-23$

(Россия, Москва)

idsp: scienceconf-25-12-2019-23

\section{Abstract}

Species-specific signals, accepted in early postnatal ontogeny, are significant for development of organism in this period and later. Nursing mother is an important source of such sensory signals. The present study examined the relationship between the maternal behavior in WAG/Rij rats with genetic predisposition to absence epilepsy and the behavior of their offspring at juvenile and adult age. In the first experiment the maternal behavior in WAG/Rij rats during the first week postpartum were compared to behavior of the normal Wistar mothers. The WAG/Rij females showed lower level of maternal care manifested in a prolongation latency of return to the nest at 3-d day postpartum, a decrease of the pups shifting, and an impairment of pup carry. WAG/Rij females had significantly more frequent occurrence of abnormally 
prolonged behavioral responses also. In the second experiment we investigated the effects of feeding WAG/Rij pups of surrogate Wistar mothers on offspring behavior in the elevated plus maze at 20 and 35 postnatal days and behavior in the open field, the forced swim test, the active avoidance learning in the shuttle box at adult age. The WAG/Rij rats feeding Wistar females had higher rate of exploratory activity in the elevated plus maze and in the open field compared to rats feeding WAG/Rij dams. It was found that there are the differences in the correlation relationships of the behavioral characteristics in the exploratory tests with the indicators of performance on active avoidance learning between the rat groups. Thus, a feeding of rat pups with genetically determined absence seizures by mothers without a hereditary brain disease leads in the increase of exploratory activity and changes the behavior organization at learning in adult age.

Эпигенетические факторы обуславливают динамику развития поведения с первых дней постнатального онтогенеза. Главным источником эпигенетических воздействий для новорожденного служит поведение матери [Шишелова, Раевский, 2016; Pérez-Torrero, Rubio-Navarro, 2015; Tang et al., 2014].

Целью работы было исследование влияния материнской заботы кормящих самок на формирование поведения потомства с врожденной патологией головного мозга. В качестве модели такой патологии использовали крыс линии WAG/Rij, генетически предрасположенных к развитию абсанс-эпилепсии. Все эксперименты выполняли в соответствии с требованиями Директивы Совета Европейского Сообщества (86/609/ЕЕС) об использовании животных для экспериментальных исследований. В первой серии экспериментов было проведено сравнение материнского поведения кормящих самок крыс линии WAG/Rij и самок крыс неконвульсивной линии Wistar в первую неделю после родов. Для этого ежедневно оценивали материнское поведение впервые родивших самок крыс линии Wistar $(\mathrm{n}=7)$ и линии WAG/Rij $(\mathrm{n}=5)$ со 2-го по 7-й день послеродового периода. Использовали разработанный нами протокол регистрации оценки материнского поведения самок крыс. Каждую кормящую самку с пометом содержали в отдельной клетке в стандартных условиях. В начале эксперимента мать отсаживали из клетки на 4 минуты. В это время брали крысят поочередно в руки, осматривали и возвращали в гнездо. Появление нового, чужого запаха и оборонительные реакции крысят на прикосновение человека служили сигналом для последующей стимуляции защитных материнских реакций. Далее возвращали мать в клетку, сажая в угол, противоположный занятому гнездом, и немедленно проводили видеосъемку поведения самки в течение 10 минут. По видеофайлу оценивали следующие показатели материнской заботы: латентный период возврата в гнездо на продолжительное время (более 1 мин), наличие активных контактов матери с крысятами (вылизывания детенышей, перекладывания их в гнезде и перетаскивания по клетке), латентный период первого активного контакта с крысятами, количество активных контактов и продолжительность каждого, суммарную продолжительность актов строительства гнезда (манипуляций с опилками клетки, направленных на наращивание стенок гнезда) и «рытья тоннелей» (когда самка погружает нос в опилки и передвигается под ними), суммарную продолжительность пребывания матери в гнезде. Оценивали стратегию перетаскивания крысят - защитной материнской реакции, направленной на изменение локализации обнаруженного гнезда. Использовали следующую разработанную нами классификацию: стратегия 1 проявляется в переносе самкой только части крысят из помета в другой угол клетки или в разные части клетки при отсутствии постройки нового гнезда и укрытии перенесенных крысят, стратегия 2 проявляется во временном перетаскивании большинства или всех крысят из помета по клетке с последующим возвратом каждого крысенка в исходное гнездо, стратегия 3 проявляется в переносе всех крысят в другой угол клетки, где самка строит новое гнездо. Также регистрировали число и продолжительность актов аутогруминга кормящей самки, и наличие эпизодов поведения с высокой продолжительностью (более одной минуты без пауз) и часто повторяющихся (более 10), которые, по нашему мнению, могут отражать проявление компульсивности [Tucci et al., 2014]. Обнаружены существенные различия в материнском поведении самок крыс исследованных линий. Самки WAG/Rij по сравнению 
с самками Wistar имели статистически значимые отличия в паттернах материнского поведения, проявляющиеся в перемещении крысят и манипуляциях с материалами подстилки. При этом поведение, направленное на поддержание гигиены (вылизывание) и кормление детенышей, не различалось. У самок WAG/Rij зафиксированы сниженные суммарная продолжительность переворачивания крысят в гнезде и продолжительность одного акта перетаскивания (табл.1). У самок WAG/Rij чаще, чем у крыс Wistar, проявлялась неэффективная для терморегуляции и защиты детенышей первая стратегия перетаскивания (41\% и 11\% соответственно, two-side тест сравнения двух пропорций, $\mathrm{p}<$ $0,05)$ и реже - вторая $(45 \%$ и $74 \%$ соответственно, $\mathrm{p}<0,05)$. Наряду с этим матери WAG/Rij имели высокие по сравнению с самками Wistar показатели продолжительности манипуляций с опилками и аутогруминга, во время которых отсутствует контакт матери с детенышами (табл.1). У самок WAG/Rij зафиксированы отклонения в недельной динамике уровня материнской заботы. Максимальный уровень материнской заботы у впервые родивших самок наблюдается на 3-й - 4-й дни после родов и временно снижается на 5-й день, когда самка начинает покидать гнездо на более длительный срок [Шишелова, Раевский, 2016]. У крыс WAG/Rij на 3-й день после родов был статистически значимо увеличен латентный период возврата в гнездо по сравнению с крысами Wistar $(335 \pm 147$ с и $190 \pm 123$ с соответственно, тест Медиан, $\mathrm{p}=0,0285)$. Различий латентного периода возврата в гнездо в другие дни между самками WAG/Rij и Wistar не наблюдалось. При этом от 4-го к 5-му дню послеродового периода у всех крыс Wistar возрастал латентный период возврата в гнездо, что соответствует стандартной динамике материнского поведения, в то время как у трех самок WAG/Rij происходило, напротив, снижение этого показателя. Также у самок WAG/Rij в два раза чаще наблюдались пролонгированные и часто повторяющиеся поведенческие акты, что может свидетельствовать о затруднениях в смене поведенческих паттернов. Большинство показателей материнского поведения крыс WAG/Rij имело меньшую стабильность по популяции по сравнению с крысами Wistar (табл.1).

Таким образом, материнское поведение самок WAG/Rij в первую неделю после родов характеризуется меньшей эффективностью по сравнению с самками Wistar: уменьшением времени тактильного контакта в связи со снижением длительности актов перемещения крысят в гнезде и при перетаскивании, более частым проявлением первой стратегии перетаскивания, увеличенным времени возврата в гнездо для ухода и кормления на 3-й день послеродового периода.

Табл.1.

Показатели материнского поведения самок крыс Wistar u WAG/Rij в первую неделю после родов (среднее значение \pm C.К.О.).

\begin{tabular}{|l|c|c|c|c|}
\hline \multicolumn{1}{|c|}{ Показатель поведения } & Самки Wistar & Самки WAG/Rij & $\begin{array}{c}\text { Различие } \\
\text { средних, тест } \\
\text { Манна-Уитни, } \\
p\end{array}$ & $\begin{array}{c}\text { Различие } \\
\text { дисперсий, } \\
\text { тест Брауна- } \\
\text { Форсайта, } p\end{array}$ \\
\hline $\begin{array}{l}\text { Суммарная продолжительность } \\
\text { актов перекладывания крысят в } \\
\text { гнезде, с }\end{array}$ & $38,9 \pm 41,7$ & $6,0 \pm 6,0$ & 0,000002 & 0,009 \\
\hline $\begin{array}{l}\text { Средняя продолжительность } \\
\text { одного акта перетаскивания, с }\end{array}$ & $15,2 \pm 10,3$ & $7,4 \pm 5,6$ & 0,001 & 0,010 \\
\hline $\begin{array}{l}\text { Длительность самого } \\
\text { продолжительного акта } \\
\text { перетаскивания }\end{array}$ & $36,8 \pm 30,7$ & $16,91 \pm 11,18$ & 0,007 & 0,033 \\
\hline $\begin{array}{l}\text { Суммарная продолжительность } \\
\text { актов строительства гнезда, с }\end{array}$ & $20,9 \pm 28,2$ & $51,2 \pm 42,0$ & 0,010 & 0,010 \\
\hline $\begin{array}{l}\text { Суммарная продолжительность } \\
\text { актов «рытья», с }\end{array}$ & $15,1 \pm 13,6$ & $32,5 \pm 30,1$ & 0,040 & - \\
\hline $\begin{array}{l}\text { Суммарная продолжительность } \\
\text { актов аутогруминга, с }\end{array}$ & $30,4 \pm 35,0$ & $132,0 \pm 120,2$ & 0,00005 & 0,000009 \\
\hline Число актов аутогруминга & $3,27 \pm 1,91$ & $5,21 \pm 3,68$ & 0,015 & 0,010 \\
\hline $\begin{array}{l}\text { Средняя продолжительность } \\
\text { одного акта аутогруминга, с }\end{array}$ & $20,0 \pm 19,0$ & $65,0 \pm 63,1$ & 0,00006 & 0,009 \\
\hline
\end{tabular}


Во второй части работы исследовали поведение самцов крыс линии WAG/Rij, выращенных самками той же линии, и самками крыс линии Wistar. Для исследования отбирали самок WAG/Rij и Wistar, родивших в один день. На 3-й день жизни крысят WAG/Rij проводили замену родившей их самки на лактирующую самку Wistar (опытная группа) или на другую самку WAG/Rij (контрольная группа). В возрасте 20-ти и 35-ти дней тестировали поведение самцов в приподнятом крестообразном лабиринте (ПКЛ). После этого самцов WAG/Rij содержали группами в отдельных клетках. Во взрослом возрасте оценивали показатели поведения в тестах «открытое поле», «принудительного плавания» Порсолта и при обучении условному рефлексу двустороннего избегания (УРДИ) в челночной камере.

Обнаружено, что у крысят WAG/Rij, выращенных самками Wistar (n=18), в возрасте 20-ти дней была выше исследовательская активность в открытых коридорах ПКЛ: статистически значимо больше длина пройденного пути (тест Манна-Уитни, $\mathrm{p}<0,05)$ и выше вариабельность показателей поведения (тест Брауна-Форсайта, $\mathrm{p}<0,05)$ по сравнению с контрольной группой крыс, выращенных самками WAG/Rij (n=21). B возрасте 35-ти дней у крыс экспериментальной группы были больше длина пути, суммарно пройденного в ПКЛ, и в его открытых отсеках, время пребывания в открытых отсеках, скорость перемещения в закрытых коридорах лабиринта, число стоек, свешиваний вниз из открытых отсеков, а также число актов груминга по сравнению с контрольной группой (тест Манна-Уитни, $<<0,05$ ). Это свидетельствует о повышенной исследовательской активности экспериментальных животных в критический период перехода к самостоятельному существованию. При оценке динамики показателей поведения в ПКЛ (парный тест Вилкоксона, $\mathrm{p}<0,01$ ) обнаружено, что у крыс опытной группы от 20-го к 35-му дню жизни существенно увеличивались общие длина пути и средняя скорость движения, возрастали средняя и максимальная скорости движения в закрытых коридорах, уменьшалась продолжительность «сидения без перемещений», что отражает увеличение двигательной активности. У крыс этой группы к 35-му дню жизни также снижалось время пребывания в закрытом отсеке, увеличивались число стоек и свешиваний вниз из центральной площадки, что отражает рост исследовательской активности. У крыс контрольной группы наблюдалось меньше статистически значимых изменений поведения в ПКЛ от 20-го к 35-му дню жизни. В закрытых коридорах у этих животных увеличивалась только максимальная скорость перемещения, что при отсутствии статистически значимых изменений других показателей двигательной и исследовательской активностей, по-видимому, характеризует увеличение активнооборонительной реакции избегания. В открытых коридорах у них возрастала средняя скорость движения и уменьшалась продолжительность «сидения», наряду с отсутствием увеличения длины пути. Эти явления, вероятно, отражают снижение пассивнооборонительного поведения в опасных отсеках. Таким образом, у крыс опытной группы в ювенильный период происходило развитие исследовательского поведения, выявляемое в ПКЛ. У крыс контрольной группы не наблюдалось изменений исследовательской активности в этом возрасте.

Во взрослом возрасте у крыс линии WAG/Rij, выращенных самками Wistar (n=16), была статистически значимо выше исследовательская активность в «открытом поле» (больше длина пройденного пути во всем открытом поле и в потенциально опасной центральной зоне, скорость перемещения и число стоек, $\mathrm{p}<0,05$, тест Медиан) по сравнению с крысами, выращенными самками WAG/Rij $(\mathrm{n}=20)$. В тесте Порсолта у первых зафиксирована меньшая суммарная продолжительность эпизодов «быстрого» плавания (со скоростью более $10 \mathrm{~cm} / \mathrm{c}$ ), истощающего физические ресурсы животных. При этом не отмечалось статистически значимых различий между группами по времени иммобильности.

В тесте УРДИ достигли критерия обученности (5 условных реакций из 6 сочетаний) 95\% крыс, выращенных самками WAG/Rij и 69\% крыс, выращенных самками 
Wistar. Различия статистически значимы (two-side тест сравнения двух пропорций, $\mathrm{p}<$ 0,05). Остальные показатели обучения УРДИ животных исследованных групп не различались. Снижение доли обучившихся животных в экспериментальной группе, возможно, отражает формирование иной структуры поведения при обучении оборонительному условному рефлексу у таких животных. Анализ связей между показателями поведения в использованных нами для взрослых животных тестах показал, что у крыс, выращенных самками WAG/Rij, продолжительность обучения УРДИ статистически значимо положительно коррелировала со скоростью перемещения в «открытом поле» и длиной пути в центральной зоне, что отражает негативную связь эмоциональной реактивности и обучаемости у контрольных животных. У крыс, выращенных самками Wistar, подобных связей не было обнаружено, что говорит о снижении связи между системами, организующими исследовательское поведение и оборонительное. При этом для этой группы было характерным большее число корреляций между показателями обучения УРДИ, что, возможно, свидетельствует о большей специфичности опыта, приобретаемого при обучении таких животных новому навыку.

Заключение. Самки крыс линии WAG/Rij, генетически предрасположенной к развитию абсанс-эпилепсии, проявляют сниженный уровень материнской заботы в первые дни постнатального онтогенеза. Выкармливание крысят WAG/Rij здоровыми самками Wistar, не имеющих наследственных заболеваний головного мозга, приводит к формированию более выраженного исследовательского поведения и изменяет структуру поведения потомства при обучении во взрослом возрасте.

\section{Работа поддержана грантом РФФИ № 17-06-00404 - ОГН ****}

1. Шишелова А.Ю., Раевский В.В. Влияние опыта материнства на формирование видоспецифического поведения потомства в раннем онтогенезе // Журнал эволюционной биохимии и физиологии. 2016. T.52. № 5. C. 347-353.

2. Pérez-Torrero E., Rubio-Navarro L. Maternal Behavior Their Adjustments and Implicated Factors. Journal of Behavioral and Brain Science. 2015. Vol. 5 (2). P. 40-55. URL: http://dx.doi.org/10.4236/jbbs.2015.52004.

3. Tang A.C., Reeb-Sutherland B.C., Romeo R.D., McEwen B.S. On the causes of early life experience effects: evaluating the role of mom. Front Neuroendocrinol. 2014. Vol. 35 (2): 245-51. doi: 10.1016/j.yfrne.2013.11.002.

4. Tucci M.C., Dvorkin-Gheva A., Johnson E., Cheon P., Taji L., Agarwal A., Foster J., Szechtman H. Performance of compulsive behavior in rats is not a unitary phenomenon - validation of separate functional components in compulsive checking behavior. Eur J Neurosci. 2014. Vol. 40 (6): 2971-9. doi: 10.1111/ejn.12652. 
Для заметок 
Scientific publication

\section{Global science. Development and novelty}

The collection of scientific papers of the materials X International scientific conference "Global science. Development and novelty"

25.12.2019

\section{Part 1}

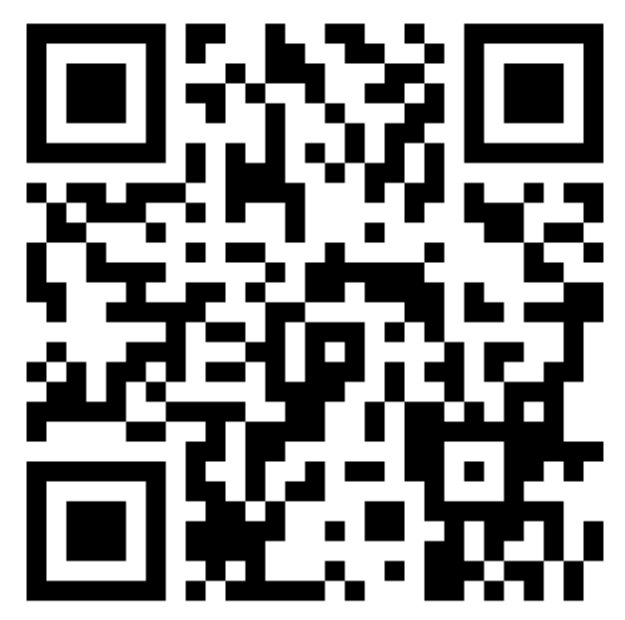

SPLN 001-000001-0562-GS

Signed print 09.01.2020. Circulation 400 copies.

Format.60x84 1/16.

Paper, offset. Printing operative.

Printed by SIC "LJournal"

Editor Chief: Ivanov Vladislav 